THE LONDON SCHOOL

OF ECONOMICS AND

POLITICAL SCIENCE

Economic History Working Papers

No: $268 / 2017$

\title{
Socialist Growth Revisited: Insights from Yugoslavia
}

Leonard Kukić

London School of Economics 


\title{
LONDON SCHOOL OF ECONOMICS AND POLITICAL SCIENCE \\ DEPARTMENT OF ECONOMIC HISTORY \\ WORKING PAPERS
}

NO. 268 - OCTOBER 2017

\section{Socialist Growth Revisited: \\ Insights from Yugoslavia ${ }^{1}$}

\author{
Leonard Kukić \\ London School of Economics, Department of Economic History \\ e-mail: L.Kukic@1se.ac.uk
}

\begin{abstract}
Beyond the recent past, and beyond the Soviet Union, we know little about the performance of Eastern European economies. This paper fills the knowledge void by analyzing socialist Yugoslavia using a diagnostic tool that identifies the mechanisms that drive economic growth - business cycle accounting. The analysis provides novel findings. During the "Golden Age" of economic growth, total factor productivity became gradually more important in sustaining economic growth. Distorted labour incentives were a major constraint on growth since the mid-1960s, and explain the slowdown of the economy during the 1980s. Socialist growth was primarily handicapped by poor incentives to work, rather than by poor incentives to innovate or to imitate. In an attempt to liberalise the economy, economic power was delegated to the labour-managed firms. These firms were maximising income per worker, which I hypothesise hindered the ability of Yugoslavs to work.
\end{abstract}

Keywords: Economic Growth; Economic History; Yugoslavia; Socialism

JEL Classification Numbers: E02, N14, 047, P27

\footnotetext{
${ }^{1}$ I thank my PhD supervisors Max-Stephan Schulze and Tamás Vonyó for their invaluable feedback and support. I also thank Stephen Broadberry, Evan Kraft, Ricardo Lago, Albrecht Ritschl, Joan Rosés and Brian Varian for their suggestions. I benefited from presenting at the LSE, the Croatian National Bank, the University of Lund, and the University of Cambridge. All errors are mine.
} 


\section{Introduction}

Socialism was the greatest social, political and economic experiment of the twentieth century. Yet, beyond the Soviet Union and China, economists and historians largely neglect the performance of socialist economies. This is all the more surprising given the lessons these economies can provide to the perennial debates about the viability of state-led development strategies. Yugoslavia is, perhaps, the most peculiar case from which we can learn about the economics of socialism. Yugoslavia was the fastest growing socialist economy in the post-WWII era (Sapir, 1980). In fact, it was one of the fastest growing countries in Europe during the 1950s and the 1960s (Balassa and Bertrand, 1970). Socialism is mostly associated with central planning. Yugoslavia was, however, heralded by contemporaries as a template for market socialism and democratic socialism. To many it symbolized the "third way" between central planning and the market economy. Thus, Horvat (1971) attributed Yugoslavia's growth performance to its labour-managed firm and to its decentralised socialist system that relied on market forces to a greater extent that did other socialist systems. But, the Yugoslavian socialist engine eventually ran out of steam, with economic growth coming to a standstill during the 1980s. Subsequently, the country disintegrated. The aim of this article is to determine the sources of Yugoslavia's economic growth during the post-war period, while focusing on the causes of its growth slowdown.

How can one account for the episodes of success and failure in an economy? Growth accounting is a useful tool to depict the development trajectory of an economy over time. But, since growth accounting focuses only on the supply side, it cannot provide an explanation for the evolution of capital, labour, and total factor productivity (TFP). I use an alternative methodology, namely business cycle accounting (BCA) methodology that preserves an accounting purpose, but moves towards the direction of explanations. BCA, developed by Cole and Ohanian (2002) and Chari, Kehoe, and McGrattan (2007), is a based on a standard neoclassical growth model, but includes "wedges". These wedges measure the deviations of an economy from the perfectly competitive market economy in the domains of labour, capital, TFP, and demand. The wedges measure distortions or incentives that firms and households face.

This paper presents two key findings. First, until the 1980s, the rate of TFP growth was roughly constant. Since the growth rate of output per capita gradually declined, the share of economic growth due to TFP increased. During this period, TFP was likely driven by structural 
change, possibly by efficiency gains stemming from the gradual integration of Yugoslavia into the global economy, and possibly by the increased adoption rate of technology. Even though TFP did decrease towards the end of the 1980s, it did not drive growth retardation of the 1980s. These findings are consistent with the notion that, in its early stages, growth is primarily associated with capital accumulation, while TFP becomes more important in later stages of growth (Collins and Bosworth, 1996; Iacopetta, 2010). These findings, however, contradict most of previous research on socialist countries. Existing growth accounts of planned economies typically find a declining rate of TFP growth, and in the 1980s often negative TFP growth (Ofer, 1987; Bergson, 1989; van Ark, 1996; Allen, 2003). The findings of this paper are instead similar to the recent revisionist literature that challenges this view. Using downwardly revised investment data, Vonyó and Klein (2017) find higher TFP growth rates in socialist European economies compared to other existing studies. ${ }^{1}$

Second, the labour wedge is quantitatively the most important determinant of the retardation of Yugoslavia's economic growth. The labour wedge corresponds to the discrepancy between the marginal rate of substitution between consumption and leisure, and the marginal product of labour. The labour wedge is related to the structure of incentives determining the provision of labour. It is often interpreted as synonymous with the distortive effect caused by labour taxation. The labour wedge embarked on a steady worsening trend since 1965. This coincides with the 1965 socio-economic reforms. These reforms allowed the work councils of labour-managed firms to distribute income between wages and investment. I argue that this allowed labour-managed firms to approach their governing objective of maximising income per worker, distorting the ability of Yugoslavs to provide labour. Through restricting new labour entry, the already employed workers gained at the cost of the outsiders. Along the lines of theory of distributional coalitions capturing rents by Olson (1982), the work councils of labourmanaged firms obstructed efficient allocation of labour. The opening of borders compounded the macroeconomic implication of distorted labour incentive. With increasing domestic unemployment, a large fraction of Yugoslavs responded by emigrating, draining the domestic supply of labour.

This paper contributes to the literature on socialist economic growth. By focusing on Yu-

\footnotetext{
${ }^{1}$ Other revisionist literature tends to stress the neglected factors in the existing literature on socialist economic growth. For instance, Vonyó (2017) argues that the relative underperformance of socialist European economies compared to the Western market economies was largely caused by labour supply inflexibility induced by comparatively larger WWII population loses.
} 
goslavia, I move past the overwhelming focus of literature on the economic performance of the Soviet Union. The existing literature uses two analytical models to explain the decline and failure of socialist economies. Under a Cobb-Douglas production function with unit factor substitution, the (comparative) decline is attributed to the (comparative) decline of TFP growth (Bergson, 1979, 1983, 1987a, 1989; Gomulka, 1977; Desai and Martin, 1983; Allen, 2003; Broadberry and Klein, 2011). Under a constant elasticity of substitution (CES) production function with low elasticity of factor substitution, the decline is attributed to diminishing marginal product of capital (MPK) (Weitzman, 1970; Desai, 1976; Sapir, 1980; Rusek, 1980; Easterly and Fischer, 1995). I contribute to this strand of literature by providing an alternative explanation for Yugoslavia's output retardation. I argue that labour constraints were the most important relative contributor to Yugoslavia's growth retardation. ${ }^{2}$ This does not mean that declining TFP and declining MPK are irrelevant explanations. TFP certainly did not boost economic growth during the 1980s, and Yugoslavia did encounter diminishing MPK since the early 1960s. However, relative to the labour wedge, these factors were of second-order importance.

The limitation of the aforementioned debate is that it does not move past what Maddison (1988) calls the "proximate" sources of growth. The inability of Eastern European countries to converge towards income levels of their market-oriented neighbours is attributed to the embedded inefficiencies of socialist economies (Kornai, 1980). Incentives for innovation were poor (Berliner, 1976), labour was demoralized (Ofer, 1987), and the system was unable to adapt to the requirements of flexible production technology (Broadberry and Klein, 2011). Thus, Krugman (1994) argues that socialist economies were bound to fail. I contribute to this strand of literature that focuses on what Maddison (1988) calls the "ultimate" sources of growth by analysing the impact of the labour-managed firm on the incentive to provide labour. If Yugoslavia was characterized by embedded disincentives that caused its failure, these poor incentives were not primarily related to incentives to innovate or imitate, but rather related to the incentives to work.

The remainder of the paper is organized as follows. Section 2 describes the evolution of the Yugoslav economic system. Section 3 defines the model, it specifies the used wedges, and it discusses the BCA procedure and related assumptions. Section 4 describes the data sources

\footnotetext{
${ }^{2} \mathrm{My}$ explanation of Yugoslavia's slowdown can be perceived as intermediate one between the TFP decline and diminishing MPK. Constrained labour input implies a low rate of labour utilization. If not accounted for, low factor utilization is reflected in low TFP. I argue that labour was the binding factor on growth, which is somewhat implied by the articles that focus on role of diminishing MPK.
} 
and parameters. Sections 5 and 6 present the results. Here, I provide detailed interpretation(s) concerning the evolution of each wedge. Finally, section 7 provides a conclusion, and includes remarks on the significance of the Yugoslav experience for wider developmental concerns.

\section{Historical context}

The strong anti-fascist resistance movement, led by the Communist Party of Yugoslavia (CPY) and its leader, Tito, was able to assert political power after the end of WWII. The CPY did not face significant political opposition in the immediate post-war period. It was backed, to an extent, by genuine popular support (Lampe, 2000). The fight against the Axis powers and their domestic collaborators legitimated it.

The evolution of the socialist economic system in Yugoslavia can be divided into four phases that can be perceived as a gradual move from central planning through market socialism to decentralised planning. The first period, during 1945-51, was characterized by rigid central planning stressing heavy industrialisation along the development model set by the Soviet Union (Horvat, 1971).

The split between the Yugoslav president Tito and the Soviet leader Stalin in 1948 was a pivotal moment in Yugoslav history. ${ }^{3}$ Yugoslav authorities initially attempted to regain Stalin's favour. As rapprochement with the Soviet Union turned impossible while Stalin lived, Yugoslav officials sought to distance themselves from the Soviet Union and its ideology. They started constructing a unique version of socialism. This period marks the second phase of development that lasted until 1965. Collectivisation and binding output targets were abandoned, as well as the most egregious price distortions. A substantial degree of decision-making power was delegated to enterprises (Prout, 1985). Firms became labour-managed, or organized along the principles of self-management. Work councils, supposedly representing the interests of workers, could, in conjunction with the local government, hire and fire the managers of the enterprise. Moreover, they could decide, to a degree, on marketing and production processes of an enterprise (Horvat, 1971).

Even though economic decision-making power was substantially decentralised, the Federal authorities still possessed effective control over the economy through the General Investment Fund. The creation of the Fund during the early 1950s replaced direct budget transfers as a

\footnotetext{
${ }^{3}$ See Rajak (2011) for the description of the episode.
} 
Figure 1: Trade (exports and imports) as percentage of GDP (1990 Int. GK\$), and composition of trade, Yugoslavia, 1952-89
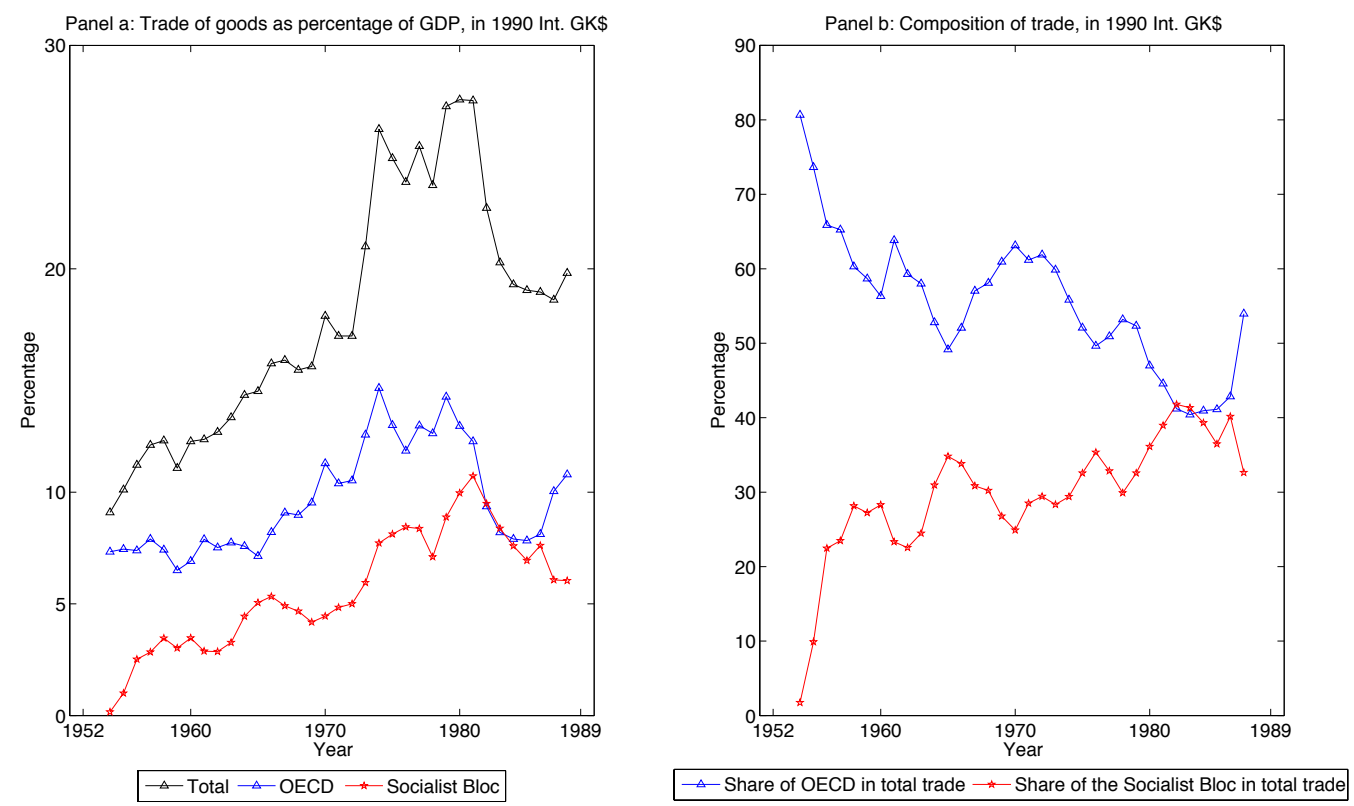

Notes: Measure of trade openness in figure 1.a can be considered real, since GDP is PPP adjusted.

Sources: Value of trade is taken from Jugoslavija 1918-1988: Statistički Godišnjak (Savezni Zavod za Statistiku, 1989) and Statistički Godisšnjak SFR Jugoslavije (SGJ) (Savezni Zavod za Statistiku, 1991), and composition of trade is taken from OECD $(1965,1990)$

main source of investment finance. The Fund centralised capital, which was then allocated to firms that either promised highest returns in investment auctions, or were deemed worthy of investment for political reasons (Bičanić, 1973).

During the 1950s, Yugoslavia began gradually opening up to the West. Figure 1.b illustrates that Yugoslavia conducted most of its trade with the OECD countries. This is not to say that Yugoslavia was particularly open to the West, or to the wider global economy. Its share of total trade as percentage of gross domestic product (GDP, 1990 Int. GK\$) remained at relatively low levels during the 1950s (figure 1.a). Nevertheless, Yugoslav trade with both the OECD club and the Socialist Bloc gradually increased (figure 1.a).

The economic reform of 1965 opened the third phase of development that lasted until 1974. It was a heyday of market socialism. Yugoslavia joined the General Agreement on Tariffs and Trade (GATT) in 1966. Figure 1.a shows that the entrance into the GATT coincides with a strong increase in Yugoslav trade with the OECD countries. In addition to this, market forces were strengthened through a liberalisation of prices, and through allowing enterprises to engage freely in foreign trade. Crucially, work councils of labour-managed firms were granted almost complete autonomy over the distribution of net income between further investment and higher 
wages. Furthermore, the previous fixed charge on the usage of capital by firms (it was a cost on capital in the absence of capital markets) designed to finance the General Investment Fund was scrapped. Banks became the primary financial intermediary, as opposed to the General Investment Fund in the previous period. Banks were intended to be the institutional channel through which scarce resources would be allocated to their most productive use. In effect, banks were subsidizing capital, and formed the soft budget constraint that firms faced (Prout, 1985; Uvalić, 1992). That is, along the lines of the theory of soft budget constraint formulated by Kornai $(1979,1980)$, firms had assured access to credit. Poorly performing firms were rarely denied credit (Prout, 1985; Uvalić, 1992).

One of the main aims of the economic reforms of 1965 was to increase the plough-back of profits into the enterprises through decreased taxation of enterprise revenues. The aim was to increase the real return on investment by incentivising firms to strengthen their riskassessment capabilities. The total share of enterprise self-financing of fixed investment increased substantially from 28 per cent in 1965, to over 50 per cent in 1966 (Uvalić, 1992).

Since unemployment increased, a 1966 government bill opened Yugoslav borders to all labourers who wished to work abroad. Yugoslavs responded en masse. By 1981, approximately 10 per cent of labour moved to the West, primarily West Germany (Lampe, 2000).

The 1974 constitution further decentralised economic power. This ushered in the last phase of the economic system that lasted until the implosion of the country in 1991. Economic power was decentralised to departmental level within firms. Decentralisation of this type, however, did not make the economy more market oriented. On the contrary, it was a period of deliberalisation. The 1974 constitution institutionalised the backlash of political elites against the increasingly independent managers. The economy became clogged with overregulation operated by overlapping authorities that formalized the relationship between the departments within a firm, between firms within a sector, between the sectors, and so on. Pejovich (1980) called this a system of contractual self-management that led to an increase in transaction costs and efficiency loss in the transmission of market information.

\section{Methodology}

BCA methodology is based on the standard Ramsay-Cass-Koopmans growth model, but includes wedges. Chari, Kehoe, and McGrattan (2007) and Brinca, Chari, Kehoe, and McGrat- 
$\tan (2016)$ argue that a large set of dynamic general equilibrium models are equivalent to a prototype neoclassical growth model embodying wedges in the first order conditions. BCA identifies the evolution of incentives (wedges) that firms and households face. The wedges can be thought of as shocks that influence decisions of economic agents. They together drive the overall economic growth. I use the labor wedge, capital wedge, income wedge, and efficiency wedge (TFP), and describe them below.

\subsection{Prototype Ramsay-Cass-Koopmans model}

The infinitely lived representative household derives utility at period $t$ from per capita consumption $\left(c_{t}\right)$ and leisure $\left(1-l_{t}\right)$ :

$$
\sum_{t=0}^{\infty} \beta^{t} N_{t}\left[\log \left(c_{t}\right)+\phi \log \left(1-l_{t}\right)\right]
$$

where $N_{t}$ denotes the working age population, and $\phi$ is the coefficient for leisure. The household discounts consumption and leisure with the factor $\beta$.

The representative firm is characterized by the Cobb-Douglas production function as in Hall and Jones (1999):

$$
Y_{t}=K_{t}^{\theta}\left(x_{t} h_{t} L_{t}\right)^{1-\theta}
$$

where $Y_{t}$ denotes output, which is a function physical capital $\left(K_{t}\right)$, labour augmenting technological progress $\left(x_{t}\right)$, human capital per worker $\left(h_{t}\right)$, and labour $\left(L_{t}\right) . \theta$ is the elasticity of output with respect to physical capital. Assuming constant returns scale, $1-\theta$ is the elasticity of output with respect to labour augmented by quality $\left(x_{t} h_{t} L_{t}\right)$. All the components of output are determined outside the model, except physical capital, which is characterized by the usual law of motion:

$$
K_{t+1}=(1-\delta) K_{t}+I_{t}
$$

where $\delta$ is the depreciation rate, and $I_{t}$ denotes gross investment.

In addition to the production function in equation 2, the equilibrium of a prototype neoclassical growth model is characterized by the following three equations:

$$
\frac{(1-\theta) y_{t}}{l_{t}}=\frac{\phi c_{t}}{\left(1-l_{t}\right)}
$$




$$
\begin{gathered}
\frac{(1+\gamma) c_{t+1}}{c_{t} \beta}=1+\theta \frac{y_{t+1}}{k_{t+1}}-\delta \\
c_{t}+i_{t}=y_{t}
\end{gathered}
$$

where $Y_{t}, I_{t}$, and $K_{t}$ are expressed in per capita terms as $y_{t}, i_{t}$, and $k_{t}$, respectively. $\gamma$ is the growth rate of labour augmenting technological progress. The household's first order condition in equation 4 states that the marginal product of labour (left-hand side) should be equal to the marginal rate of substitution between consumption and leisure (right-hand side). It determines the equilibrium condition for the supply of labour. Equation 5 defines the growth rate of consumption, by specifying that the intertemporal marginal rate of substitution (left-hand side) should be equal to the cross-period return on investment (right-hand side). ${ }^{4}$ Equation 6 describes the resource constraint of the economy, by specifying that the total income of the economy (right-hand side) is spent on either consumption or investment (left-hand side).

\subsection{Wedges}

The rationale of $\mathrm{BCA}$ rests on the observation that, in real economies, the terms on the sides of equation 2, and of equations 4-6, tend to be different. These differences are regarded as wedges. These wedges measure the distortions that economic agents face.

The efficiency wedge, or TFP, measures the efficiency with which inputs are transformed into output. As in real business cycle models, the TFP wedge is measured as the deviation around the constant growth rate of labour-augmenting technological progress $(\gamma)$, or balancedgrowth path. The model thus focuses on the accelerations or decelerations of growth around the balanced-growth path. Formally, TFP is based on equation 2, and is defined as:

$$
z_{t}=\frac{y_{t}}{k_{t}^{\theta}\left(x_{t} h_{t} l_{t}\right)^{1-\theta}}
$$

The labour wedge measure the discrepancy between the marginal rate of substitution of consumption for leisure, and the marginal product of labour. Incentives that drive the supply of labour to deviate from the level implied by equation 4 are reflected in the labour wedge $\left(1-\tau_{l, t}\right)$ :

\footnotetext{
${ }^{4}$ I assume that economic agents have perfect foresight.
} 


$$
1-\tau_{l, t}=\frac{\frac{\phi c_{t}}{\left(1-l_{t}\right)}}{\frac{(1-\theta) y_{t}}{l_{t}}}
$$

The labour wedge is related to the structure of incentives that determine the supply of labour. A rising labour wedge can be interpreted as rising return on labour that stimulates the provision of labour. The labour wedge is often interpreted as synonymous with the distortive effect caused by labour taxation (Prescott, 2004; Chari, Kehoe, and McGrattan, 2007; Ohanian, Raffo, and Rogerson, 2008). As such, a deteriorating labour wedge can be interpreted as a distortion arising due to increased taxation of labour - e.g. due to increased income taxation. For instance, if the marginal product of labour increases and the marginal rate of substitution remains constant, the labour wedge will deteriorate. Households are not receiving the proceeds of their product in the form of higher consumption or leisure. Following the tax analogy, this is equivalent to being taxed more.

The capital wedge measures the frictions that distort the intertemporal Euler equation, which specifies the trade-off between current and future consumption. Incentives that drive investments to deviate from the level implied by equation 5 are reflected in the capital wedge $\left(1-\tau_{k, t+1}\right):$

$$
1-\tau_{k, t+1}=\frac{\frac{(1+\gamma) c_{t+1}}{c_{t} \beta}}{1+\frac{\theta y_{t+1}}{k_{t+1}}-\delta}
$$

The capital wedge is related to the structure of incentives determining saving and investment. An increasing capital wedge can be interpreted as an increasing return on capital that stimulates saving and investment. Analogous to the labour wedge, a capital wedge is often interpreted as synonymous with the distortive effect caused by taxation of capital. For instance, if the crossperiod return on investment increases, given the intertemporal rate of substitution, the capital wedge will deteriorate. Households are undersaving because, following the tax analogy, the tax rate has increased.

The income wedge measures the discrepancy between output and domestic private demand - composed of consumption and investments - in equation 6. This discrepancy measures the expenditure gap in order for the resource constraint to hold. The income wedge $\left(\tau_{i, t}\right)$ measures output appropriated by the government and the foreign sector:

$$
\tau_{i, t}=y_{t}-c_{t}-i_{t}
$$


The main limitation of BCA is that the measured wedges do not interact (Christiano and Davis, 2006). Each wedge evolves independently of the others, neglecting possible spillover effects. Furthermore, in order to understand the exact incentives that, say, increase the return on the supply of labour, a researcher should specify explicit mechanisms. This is not necessarily a weakness. A model with detailed mechanisms a priori assumes the importance of the same mechanisms, which might not be the case. BCA remains agnostic ex ante about important channels that drive macroeconomic fluctuations. It provides diagnostic results without assuming which factor may or may not be an important source of growth. BCA may thus be applied to a variety of countries in a variety of time periods. Finally, BCA cannot explain the evolution of TFP because it is not an endogenous growth model. In that sense, it shares a common problem with growth accounting. Relating the empirical findings to the existing literature on Yugoslav macroeconomic history can alleviate some of the aforementioned issues.

\subsection{Fundamental assumptions}

Implied profit-maximization is a poor description of firm behaviour within a socialist economy. BCA, however, can be applied to socialist economies. Cheremukhin, Golosov, Guriev, and Tsyvinski $(2015,2017)$ use an extended BCA framework to analyse the economic growth of socialist China and Soviet Union, respectively. Cheremukhin, Golosov, Guriev, and Tsyvinski (2017) provide a detailed description of how some frictions related to Soviet Union map into a neoclassical growth model characterized by wedges. A socialist economy can thus be perceived as a distorted version (embodied by wedges) of a perfectly competitive economy. If anything, the more liberal system of Yugoslav market socialism might be more suitable for BCA application than the more rigid socialist systems like Stalin's Soviet Union and Mao's China.

Turning to the production function, the Cobb-Douglas assumption of unit substitution between capital and labour might be wrong. Weitzman (1970) argues that the Soviet economy is better represented by CES production function with factor substitution below one. The implication of low factor substitution is that the Cobb-Douglass production function fails to register the true extent of diminishing MPK. It thus underestimates the contribution of TFP to growth. If this is true, my findings would be strengthened. The finding concerning the increasing importance of TFP in sustaining growth would be strengthened, since TFP would gain a greater weight as a source of growth. The deterioration of the labour wedge since the mid-1960s would be even more pronounced because labour would gain a greater weight as a constraining factor 
of growth.

\section{Data and calibration}

\subsection{Output and inputs}

The period of analysis is between 1952 and 1989. The data this paper relies on is derived from both official and alternative sources. The aim is to maximise the quality of data. All value figures are converted into 1990 International Geary-Khamis dollars. This section briefly describes used data concerning Yugoslavia. A detailed analysis is provided in appendix A.1. For context, I include additional countries in the analysis. The data sources for these countries are reserved for the data appendix, too (A.2). U.S. is included since it remains at the technological frontier. Greece, Portugal, and Spain are included since they were at a broadly similar level of development as Yugoslavia. Like Yugoslavia, these southern European countries were also partially planned economies under autocratic regimes. I do not include other socialist economies because the available data is not reliable.

I use GDP series from Maddison (online). ${ }^{5}$ Annual employment data is taken from official sources. ${ }^{6}$ Workers employed in private farming are reported only in population censuses (1948, 1953, 1961, 1971, 1981, and 1991). ${ }^{7}$ For the remaining years of the analysis, agricultural labour is estimated through cubic interpolation. Labour is adjusted for hours worked from official sources. ${ }^{8}$ Annual labour (total hours worked) is de-trended by 3600 hours, since the representative household spends a portion of the annual time endowment satisfying biological necessities (like sleeping).

Human capital is constructed following the method of Hall and Jones (1999). Average years of schooling are turned into mincerian human capital by adjusting for the income returns to education relative to labour without education. Return to education is assumed to be piecewise linear. The return to education under 4 years of schooling is taken to be 13.4 per cent, between 4 and 8 years of schooling it is taken to be 10.1 per cent, and above 8 years of schooling it is taken to be 6.8 per cent. Years of schooling are based on Yugoslav population censuses. They

\footnotetext{
${ }^{5}$ Consumption series, however, are taken from official sources, since alternative long-run series are unavailable (SGJ, (Savezni Zavod za Statistiku, 1991)).

${ }^{6}$ SGJ (Savezni Zavod za Statistiku, 1991).

${ }^{7}$ Popis Stanovništva (Savezni Zavod za Statistiku, 1948, 1953, 1961, 1971, 1981) and International Labor Organization (ILO) for 1991 (online).

${ }^{8}$ SGJ (Savezni Zavod za Statistiku, 1952-1991).
} 
are taken from Kukić (2017).

For gross investment, I use official data, but exclude an investment category "other". ${ }^{9}$ I omit this category because, among other factors, it includes expenditure on product research and training of personnel, which is not part of physical capital. The exclusion of the category other reduces gross investment by approximately 10 per cent on an average annual basis. Gross investment is disaggregated into three components - equipment, residential structures, and nonresidential structures. Finally, I initialise capital stock series by using existing national wealth estimates. ${ }^{10}$

Some of Yugoslavia's macroeconomic data, within context, is provided in figure 2. The oil shock of 1979 seems to be associated with the deterioration of most macroeconomic variables (GDP per capita, capital to labour ratio, and investment to output ratio). By contrast, labour to the working-age population ratio, indicating labour utilisation rate, gradually deteriorated since the mid-1960s.

\subsection{Parameters}

The discount factor $(\beta)$ is assumed to be 0.95 , and the coefficient for leisure $(\phi)$ is taken to be 2. Similar assumptions are made in articles that use the same or similar methodology, and that analyse economic growth of countries at a similar level of development (Lu, 2012; Cheremukhin, Golosov, Guriev, and Tsyvinski, 2015, 2017). It is possible to estimate these parameters from the data, albeit with subjective assumptions. The estimation of these parameters is reported in appendix A.3.2. The choice of the discount factor and coefficient for leisure does not affect the results.

Assuming perfectly competitive markets, the elasticity of output with respect to capital $(\theta)$ is the capital share of income. I assume that $\theta$ is 0.4 . This is similar to the often estimated capital share of income in socialist countries (Easterly and Fischer, 1995). The remaining parameters are estimated from the data. Population growth rate $\left(v_{t}\right)$ is time varying, and is on average 1.1 per cent per annum. The growth rate of labour-augmenting technological progress $(\gamma)$ is 1.1 per cent, which is the average annual growth rate of labour-augmenting technological

\footnotetext{
${ }^{9}$ Investicije u Osnovna Sredstva SFR Jugoslavije, Socijalističkih Republika i Socijalističkih Autonomnih Pokrajina, 1952-1981, u Cenama 1972 (Savezni Zavod za Statistiku, 1983a) and Investicije (Savezni Zavod za Statistiku, 1982-1989).

${ }^{10}$ Equipment and non-residential structures are taken from the official survey of fixed assets: Osnovna Sredstva Privrede Društvenog Sektora SFR Jugoslavije, Socijalističkih Republika i Socijalističkih Autonomnih Pokrajina, 1952-1981, u cenama 1972 (Savezni Zavod za Statistiku, 1983b). Residential structures are taken from Vinski (1978).
} 
Figure 2: Macroeconomic data, Yugoslavia and sample countries, 1952-89
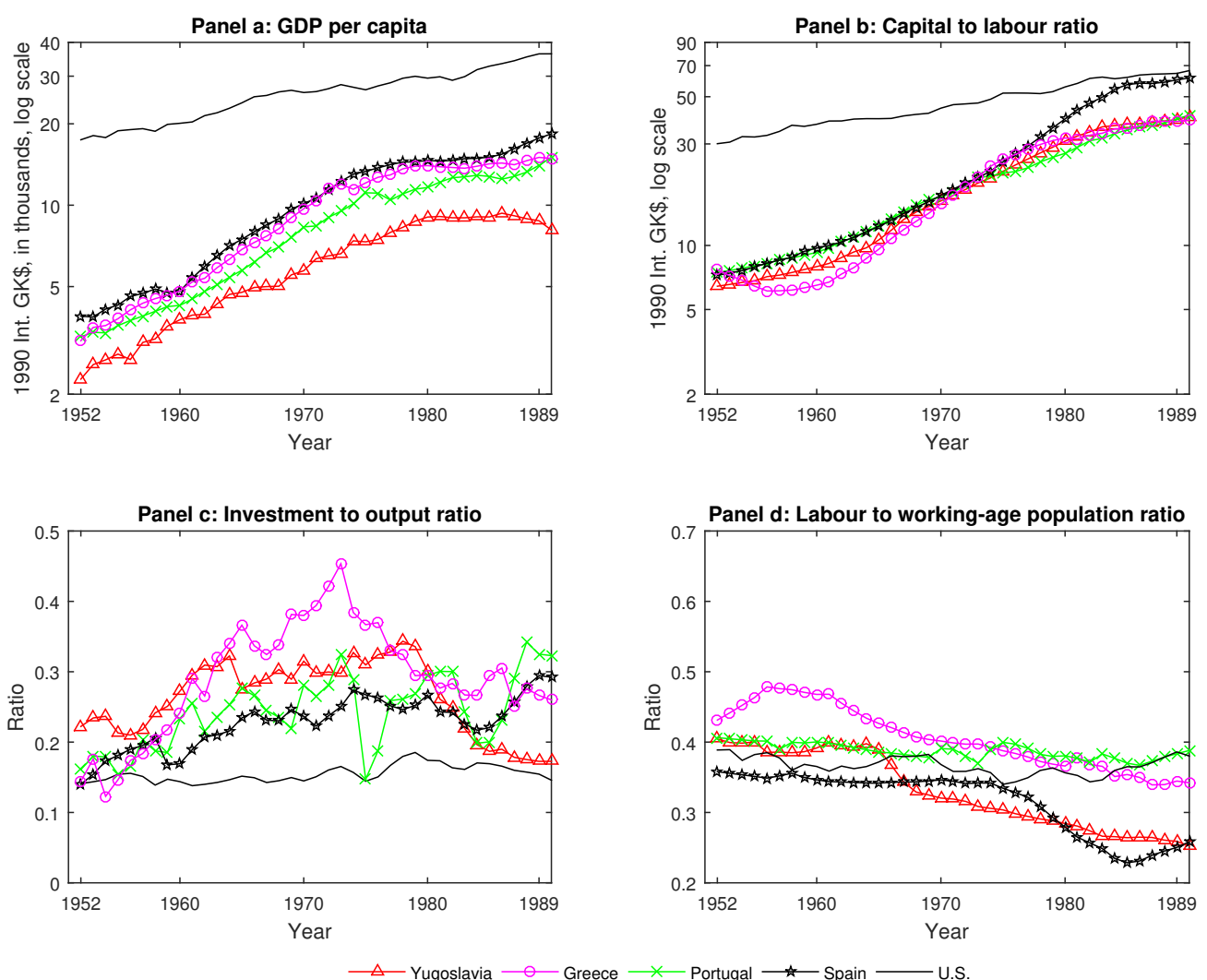

Notes: Capita is defined as working-age person (15-64) through the text. Labour is total hours worked.

progress during 1952-89. The depreciation rate $(\delta)$ is 15 per cent for equipment, 3.1 per cent for non-residential structures, and 1.3 per cent for residential structures. These depreciation rates are taken from Hulten and Wykoff (1981) depreciation rate estimates by asset type.

\section{Results: The evolution and interpretation of wedges}

Figure 3 depicts the evolution of Yugoslav wedges within context. The evolution of wedges is the cornerstone of the analysis because the growth rates are robust to a variety of assumptions and specifications, while the levels are not (see appendix A.3). In this section, I provide interpretation for the evolution of each wedge.

\section{$5.1 \quad$ TFP}

Between 1952 and 1989 Yugoslav TFP grew by 1.8 per cent on an average annual basis (figure 3.a). Table 1 compares this estimate to the TFP estimates in the existing literature. 
Figure 3: Yugoslav and sample-countries wedges, 1952-89
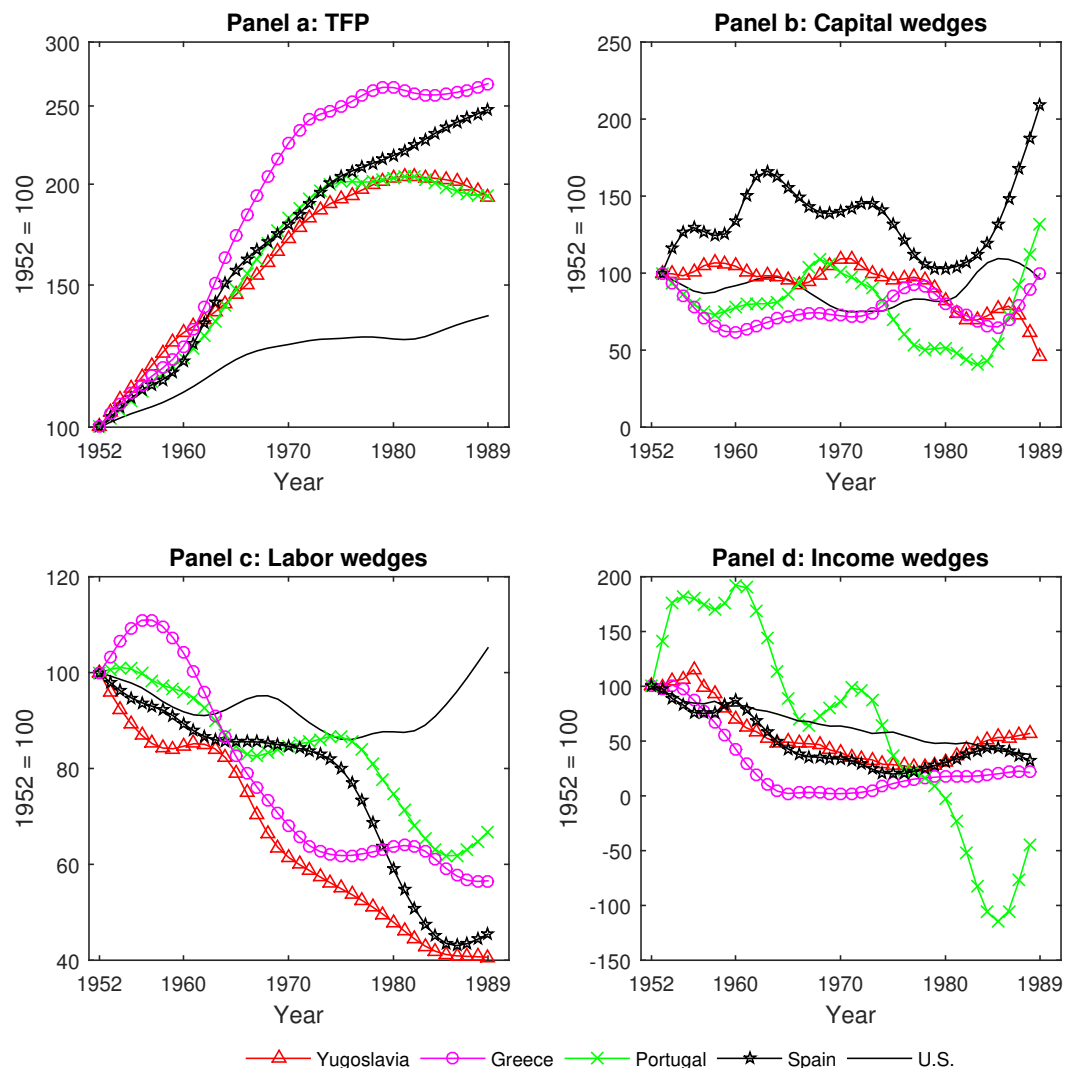

Notes: The increase in any wedge is beneficial to economic growth. However, with the exception of $\mathrm{TFP}$, an increase in the wedge does not necessarily imply that its contribution to economic growth is overall positive. It may be that the impact of a wedge on economic growth is actually negative. But, as the wedge increases, its impact on economic growth will be less damaging and, in that sense, it will be beneficial to economic growth. Business cycles are removed using the Hodrick-Prescott filter (smoothing parameter $=6.25)$. No technological growth rate is imposed $(\gamma=0)$, rendering TFP growth comparable to standard growth accounting exercises.

Measured TFP gains of this paper, as a share of output growth, fall within the mid-range of findings.

Yugoslav TFP grew faster than the U.S. TFP. This implies that Yugoslavia converged towards the global technological frontier. It seems that TFP in Yugoslavia grew at a similar rate as in Portugal, but slower than in Greece and Spain. The evolution of Yugoslav TFP can be divided into two periods - before and after the second oil shock in 1979. Before 1979, Yugoslav TFP grew rapidly. It stagnated afterwards, and decreased towards the end of the 1980s.

The literature provides a set of viable interpretations underlying the evolution of TFP. Nishimizu and Page (1982) analyse Yugoslav TFP between 1965 and 1978. They find that the evolution of TFP was driven by efficiency, rather than by technology. This is consistent with Hsieh and Klenow (2009), who argue that the efficiency of resource allocation is a major 
Table 1: Yugoslav TFP growth in the literature

\begin{tabular}{lcccc}
\hline \hline & Share of output growth due to TFP & Period & Sector & Capital share \\
\hline This paper & $46 \%$ & $1952-89$ & Aggregate & 0.4 \\
Balassa and Bertrand (1970) & $40 \%$ & $1953-65$ Manufacturing & 0.65 \\
Horvat (1971) & $43 \%$ & $1954-67$ Manufacturing & n.a. \\
Jerome (1985) & $26 \%$ & $1950-80$ & Aggregate & n.a. \\
Kukić (2017) & $32 \%$ & $1953-86$ Aggregate & 0.43 \\
Sapir (1980) & $43 \%$ & $1955-74$ Manufacturing & $0.13-0.28$ \\
Simon (2013) & $55 \%$ & $1953-89$ & Aggregate & 0.29 \\
\hline \hline
\end{tabular}

Notes: Horvat (1971) estimated TFP gains in manufacturing, construction, and crafts. The capital share of income in Sapir (1980) is time-varying. These estimates are imperfectly comparable due to differences in analysed periods, sectors, and used capital shares.

component of TFP.

Improvements in resource allocation might have been driven by reconstruction dynamics. Vonyó (2008) argues that, for core Western countries, the intensity and variety of economic growth during the 1950s and the 1960s can be mostly explained by post-war reconstruction. Post-war reconstruction might matter for socialist European countries as well. Vonyó (2010) finds that post-war reconstruction drove the growth dynamics of Hungary during the 1950s and the 1960s. Unfortunately, the quantitative contribution of reconstruction to Yugoslavia's growth is impossible to measure. Reliable macroeconomic aggregates are not available for the interwar and the immediate post-war period. It is difficult to speculate about the extent to which reconstruction efforts might have mattered.

Yugoslavia was overwhelmingly agricultural in the aftermath of World War II. But, it experienced rapid structural modernisation during the post-war period. ${ }^{11}$ Reallocation of resources from low productivity agriculture to high productivity manufacturing and modern services certainly stimulated TFP. ${ }^{12}$ Table 2 demonstrates that the sectorial labour product gap declined rapidly between 1953 and 1986. The reduction of the marginal quality-adjusted labour product gap is strongly indicative of efficiency gains associated with a process of structural modernization (column 2 of table 2) (Herrendorf, Rogerson, and Valentinyi, 2014). Moreover, it seems that TFP gains during the 1970s were sustained partially by structural modernisation, since

\footnotetext{
${ }^{11}$ According to official statistics, agricultural workers formed 74 per cent of total workforce in 1952. By 1989, agricultural workers formed 19 per cent of total workforce.

${ }^{12}$ As in other socialist economies, policy-makers attempted to stimulate structural modernization by relative price distortions. Prices of agricultural goods were set below world prices, while prices of industrial goods were set above world prices. Allen (2003) argues that such policies were conducive to the expansion of industry and aggregate output of the Soviet Union. This price distortion was gradually alleviated in Yugoslavia. According to official data, I find that the annual inflation rate of agricultural goods was on average 2 percentage points higher than that of non-agricultural goods during 1952-86 (Jugoslavija 1918-1988 Statisticčki Godišnjak, (Savezni Zavod za Statistiku, 1989)).
} 
Table 2: Relative productivity of non-agriculture and agriculture, Yugoslavia, 1953-86

\begin{tabular}{lcccc}
\hline \hline $\begin{array}{l}\text { Ratio of non-agricultural to agricul- } \\
\text { tural labour productivity }\end{array}$ & $\begin{array}{l}\text { Ratio of non-agricultural to agricul- } \\
\text { tural MPH }\end{array}$ & \\
\hline 1953 & 4.365406 & & 1.959573 & \\
1961 & 3.511758 & & 1.610309 & \\
1971 & 3.074353 & & 1.453791 & \\
1981 & 1.855458 & & 0.959013 & \\
1986 & 1.643827 & & 0.857754 & \\
\hline \hline
\end{tabular}

Notes: The marginal product of human capital (MPH) is the derivative of output with respect to labour augmented by human capital. Physical capital in agriculture includes the value of land and livestock.

Source: Sectorial level data is taken from Kukić (2017).

the reduction of the marginal product gap accelerated. ${ }^{13}$

Nevertheless, it seems unlikely that structural modernisation is sufficient in explaining the evolution of TFP. Kukić (2017) finds that efficiency gains associated with structural modernisation can account for one-quarter of conventionally measured TFP gains in Yugoslavia. Further explanations concerning the evolution of TFP are required.

Trade might, beyond boosting aggregate demand, indirectly impact output through TFP (Alcalá and Ciccone, 2004; Madsen, 2007). The gradual integration of Yugoslavia into global markets (figure 1.a) might have stimulated TFP through three channels. First, by increasing competitive pressures and hence stimulating domestic companies to improve their efficiency. Second, by allowing the internationally small Yugoslav economy to realise economies of scale by producing for foreign markets. Third, by facilitating the adoption of foreign knowledge. ${ }^{14}$

The previous interpretations focused on efficiency gains, neglecting possible technological gains. DeLong and Summers (1991) argue that machinery and equipment investment has strong association with growth. Since equipment embodies technology, equipment investment might be positively associated with growth through TFP. Moreover, Caselli and Wilson (2004) provide evidence that the composition of equipment influences TFP, since different types of equipment embody different intensities of research and development (R\&D), and hence technology. As a

\footnotetext{
${ }^{13}$ During the 1970 s, the sectorial marginal product gap was reduced by 4 per cent on an average annual basis, while in the 1950s and the 1960; it was reduced by 2.5 and 1 per cent, respectively (table 2).

${ }^{14}$ Starting in the 1960s, the development of tourism along the Adriatic coast is an illuminative example that Yugoslavia, to an extent, did specialize in the production of goods and services according to its comparative advantage (Allcock, 1986). This may have boosted TFP as long as it caused efficiency improvements and enhanced knowledge absorption. In addition to this, OECD trade in Yugoslav GDP has sharply increased following Yugoslavia's accession to the GATT in 1966 (see figure 1.a). Trade might have thus (partially) sustained TFP gains during the 1960s and the 1970s. That is, as long as the entry into the GATT realigned Yugoslav resources to more productive uses through increased trade with the OECD club, as opposed to the more autarkic socialist system.
} 
Figure 4: Equipment investment and composition of equipment imports, Yugoslavia
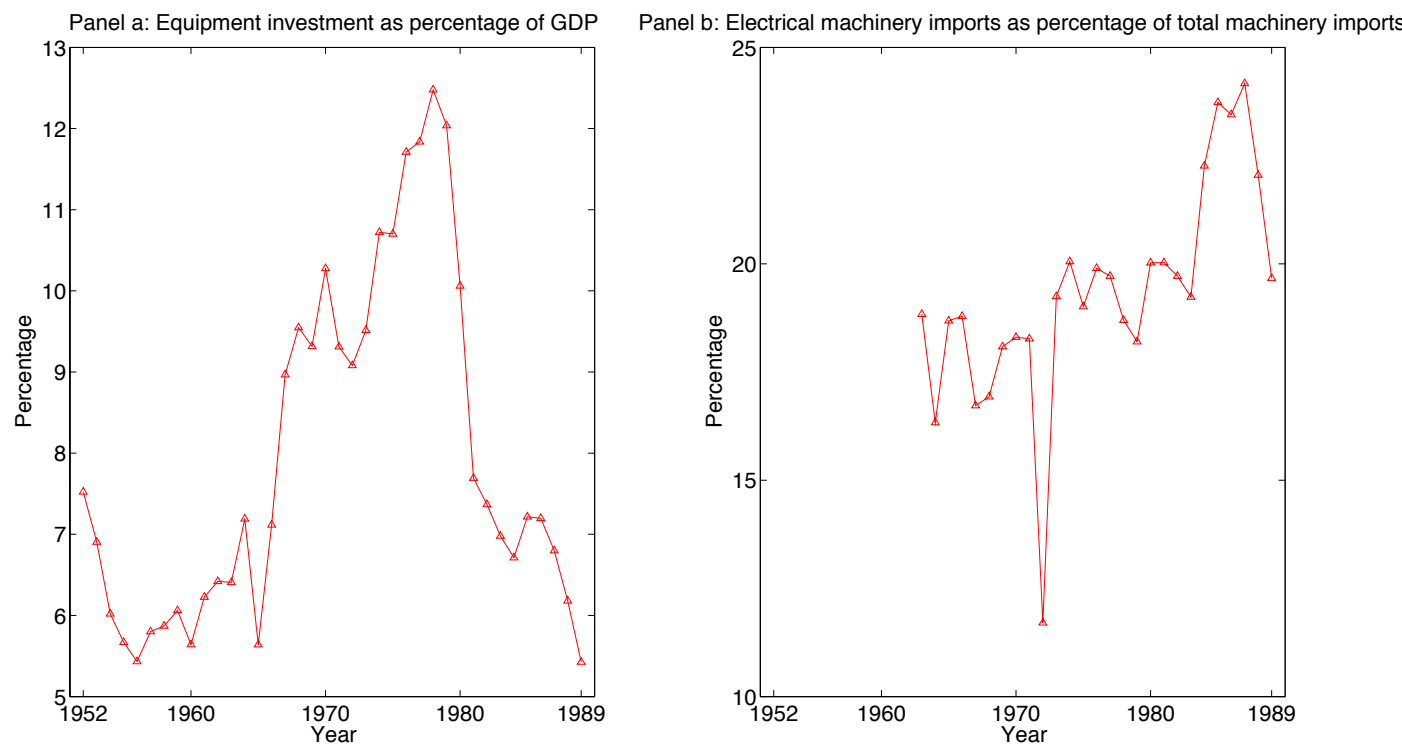

Note: It is not possible to identify the import categories of equipment before the early 1960s.

proxy for possible technological gains, I examine equipment investment as percentage of GDP and the composition of equipment investment. As a proxy for the composition of equipment investment, I examine the composition of equipment imports. Yugoslav trade statistics allow me to differentiate between electrical equipment, non-electrical equipment, trucks, and other vehicles. In the Caselli and Wilson (2004) dataset, electrical machinery is characterized by higher R\&D intensity than other types of equipment I can identify. Figure 4.a shows that equipment investment as percentage of GDP increased since the mid-1960s until the late 1970s. Figure 4.b shows that imports of electrical machinery as percentage of total machinery imports increased as well. Conjecturally, both figures suggest that increased adoption rate of technology sustained TFP gains during at least the 1970s.

Turning to the 1980s, can technology explain the stagnation of TFP? Broadberry and Klein (2011) argue that Eastern European economies performed relatively well in an era of mass production during the 1950s and the 1960s. They were, however, unable to achieve satisfactory productivity performance with the onset of flexible production technology in the late 1970s and the 1980s. Equipment investment, embodying flexible production technologies (like information and communication technologies), did precipitously decrease since the late 1970s. ${ }^{15}$ This,

\footnotetext{
${ }^{15}$ The absolute value of electrical machinery has precipitously declined, too, although its share in total machinery imports has increased (figure 4.b). For instance, between 1981 and 1985, collapsing domestic demand and severe austerity measures caused a 25 per cent decline of the nominal value of electrical machinery, even though output prices increased by a factor of five during the same period.
} 
Figure 5: Crude oil imports as percentage of output, nominal values, Yugoslavia, 1952-89

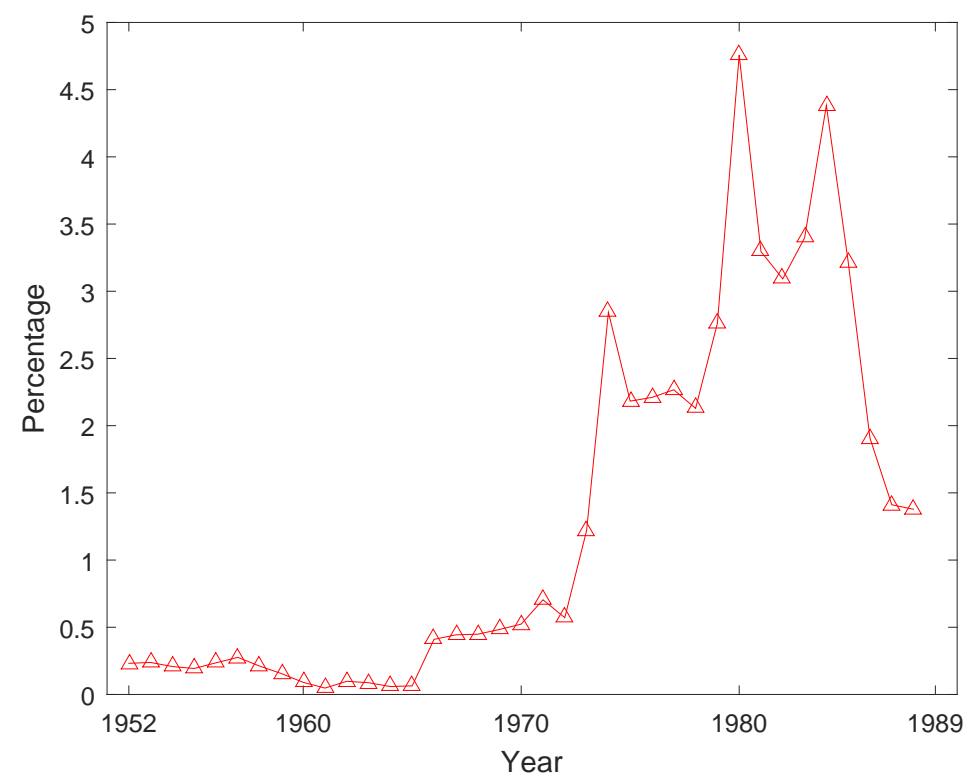

Notes: Output is Social Product (SP), the socialist equivalent of GDP. Discussion of SP is provided in appendix A.1.

Sources: Crude oil imports and nominal SP are taken from SGJ (Savezni Zavod za Statistiku, 1991) and Jugoslavija 1918-1988: Statistički Godišnjak (Savezni Zavod za Statistiku, 1989).

however, seems to be related to a deep crisis that was instigated by the second oil shock in 1979. During the 1970s, with available cheap capital in global financial markets, total external debt level increased by nearly eight times, rendering Yugoslavia vulnerable to external shocks (Dyker, 1990). External shocks came in two closely related forms.

First, the 1979 Iranian Revolution rattled the global energy markets (Hamilton, 2013). Figure 5 plots crude oil imports as percentage of Yugoslavia's output. The 1979 oil shock, as well as the 1973 oil shock, is associated with a sharp increase in this figure. Yugoslavia was particularly vulnerable to energy shocks because it was using two to three times more energy per unit of output than the OECD countries during the early 1980s (Dyker, 1990). The second oil shock was brought about by increased interest rates in creditor nations designed to reduce inflation, increasing Yugoslavia's debt-servicing costs.

The two combined effects led to a sharp increase in the current account deficit. In just one year, 1978-79, it increased by a factor of three (Dyker, 1990). With constrained export demand, the only way to avoid a crushing balance-of-payments crisis was to limit other components of aggregate demand. From 1979 to 1983, severe austerity measures resulted in a collapse of real personal incomes by approximately 30 per cent, and a precipitous fall in the investment to output ratio (figure 2.b). Aggregate demand collapsed, and did not recover during the remainder 
Table 3: Capacity utilisation rate in Yugoslav manufacturing, in per cent, 1977-89

\begin{tabular}{lc}
\hline \hline Year & Capacity utilisation \\
\hline 1977 & 81 \\
1978 & 81 \\
1979 & 81 \\
1980 & 80 \\
1981 & 80 \\
1982 & 77 \\
1983 & 77 \\
1984 & 78 \\
1985 & 77 \\
1986 & 77 \\
1987 & 76 \\
1988 & 75 \\
1989 & 75 \\
\hline \hline
\end{tabular}

Notes: Capacity utilization rate is an official estimate of feasible output, according to initial design, if factories were operating at full capacity, given capital and labor. Estimates prior to 1977 are unavailable. The level at the beginning at the sample period seems internationally comparable. For instance, the 1967-2015 U.S. average of capacity utilization is 80 per cent (Federal Reserve Bank of ST. Louis, online).

Sources: SGJ (Savezni Zavod za Statistiku, 19781990).

of the 1980s.

Recessions are typically characterized by decreased capacity utilisation of both capital and labour. If not explicitly accounted for, this would be otherwise reflected in declining TFP (Paquet and Robidoux, 2001). Table 3 shows that capacity utilisation had decreased during the 1980s. The declining utilisation rate seems to have been driven by work stoppages and labour unrest that dramatically increased during the 1980s (table 4). By contrast, hours worked by engines in plants have increased during the 1980s, according to official sources (SGJ (Savezni Zavod za Statistiku, 1978-1991)). This indicates that firm management attempted to substitute capital for labour to combat declining capacity utilisation.

\subsection{Capital wedge}

The Yugoslav capital wedge was stable until the late 1970s (figure 3.b). Afterwards, it rapidly decreased. This means that the incentive to save and invest remained stable before decreasing 
Table 4: Work stoppages in Yugoslavia, 1958-89

\begin{tabular}{ccccc}
\hline \hline & Frequency of strikes* & Number of strikes & Number of workers on strike & Media reports of strikes \\
\hline 1958 & 2.8 & $\mathrm{n} / \mathrm{a}$ & $\mathrm{n} / \mathrm{a}$ & $\mathrm{n} / \mathrm{a}$ \\
1978 & 30 & $\mathrm{n} / \mathrm{a}$ & $\mathrm{n} / \mathrm{a}$ & 3 \\
1980 & 62 & 235 & 13,504 & 8 \\
1981 & 47 & 216 & 13,507 & 24 \\
1982 & 18 & 174 & 10,997 & 36 \\
1983 & 96 & 336 & 21,776 & 86 \\
1984 & 100 & 393 & 29,031 & 158 \\
1985 & 104 & 696 & 60,062 & 795 \\
1986 & 163 & 851 & 88,860 & 320 \\
1987 & 227 & 1685 & 288,686 & $\mathrm{n}$ \\
1988 & 228 & $\mathrm{n} / \mathrm{a}$ & $\mathrm{n} / \mathrm{a} / \mathrm{a}$ & $\mathrm{n}$ \\
1989 & 232 & $\mathrm{n} / \mathrm{a}$ &
\end{tabular}

Note: ${ }^{*} 1980$ to 1989 shows data for Slovenia, a member republic of Yugoslavia.

Sources: Stanojević (2003) for the frequency of strikes; Jovanov (1989) for the number of strikes and the number of workers involved; Lowinger (2009) for media reporting of strikes.

during the late 1970s. In contrast, the Southern European capital wedges increased during the 1980s. To an extent, the relative retardation of Yugoslav economic performance during the 1980s seems to have been caused by diverging capital wedges.

The transition from a centralised provision of capital to a more market-oriented one based on investment auctions during the 1950s does not seem to be reflected in an increase of the capital wedge. Nevertheless, to examine this transition period in greater depth, it is necessary to include the period of central-planning into the analysis (1945-1951). This is unfortunately impossible given the absence of reliable data for the period. Otherwise, one can only surmise that the relegation of investment decisions from central planners to other economic agents stimulated the accumulation of capital.

The introduction of banks as an important financial intermediary in 1965, the scrapping of the fixed charge on the usage of capital, as well as the devolution of investment decisions to labour-managed firms, seems to be reflected in a slight increase of the capital wedge.

Similar to the evolution of TFP, the 1979 oil shock is a major turning point for the evolution of the capital wedge. The economy did encounter diminishing returns on capital since the early 1960s (figure 6). However, the decrease of MPK is gradual and modest. The evolution of MPK cannot explain the sharp deterioration of the capital wedge since the late 1970s in figure 1.b. Rather, it seems that the macroeconomic instability of Yugoslavia, characterized by high and persistent inflation (Frenkel and Taylor, 1993), had increased the preference to consume in the present rather than in future, causing a deterioration of the capital wedge. 
Figure 6: Marginal product of capital in Yugoslavia and sample countries, 1952-89

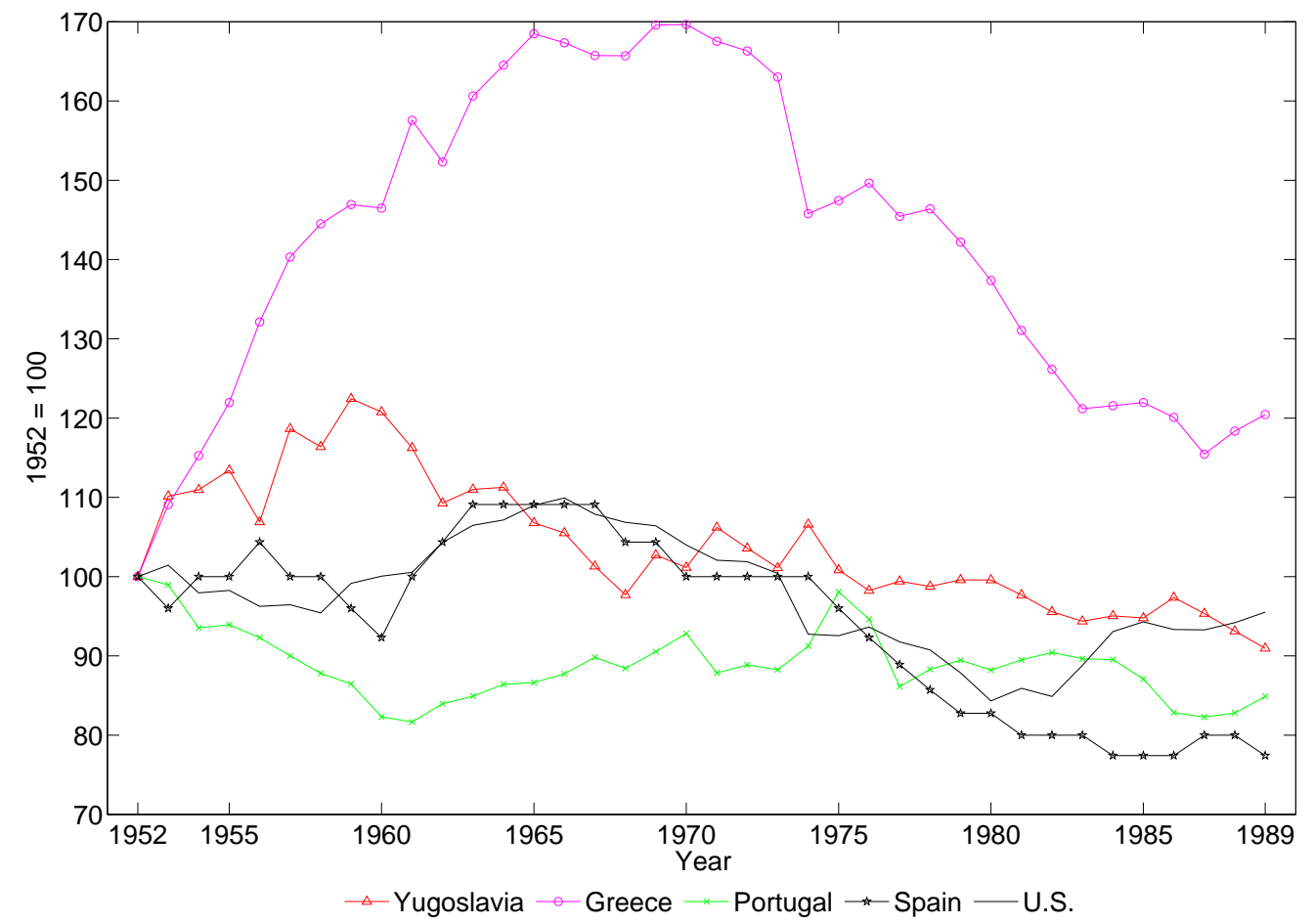

In addition, the sovereign debt crisis of the 1980s hampered access to credit (Dyker, 1990). This should be reflected in deteriorating capital wedge, because smoothing consumption and financing investment became more difficult.

\subsection{Labour wedge}

Yugoslav labour wedge initially deteriorated during the 1950s, but had stabilized by 1965 (figure 3.c). ${ }^{16}$ Subsequently, it persistently decreased. If Yugoslavia was characterized by embedded disincentives that furthermore intensified over time, they are reflected in the deterioration of the labour wedge. The incentive or ability of households to supply labour deteriorated over time.

According to figure 3.c, the steady deterioration of the labour wedge during the post-war period is not unique to Yugoslavia. Nevertheless, unlike in Yugoslavia, the labour wedges of Portugal, Spain and the U.S. have rebounded during the mid-1980s. The beginning of the steady deterioration of Yugoslavia's labour wedge coincides with the socio-economic reforms of 1965. Although labour-managed firms were formally established in 1950, they did not operate

\footnotetext{
A.3.4.

${ }^{16}$ The initial decline of the labor wedge is explained by the existence of subsistence consumption in appendix
} 
freely outside government control until 1965 (Sapir, 1980; Estrin, 1983). The 1965 reforms, as mentioned in section 2, provided almost complete autonomy to labour-managed firms to distribute their net income between wages and investment.

A large group of scholars argue that labour-managed firms were maximising income per worker (Ward, 1958; Vanek, 1970; Meade, 1972; Estrin, 1983). Moreover, their governing objective was reinforced by the 1965 reforms (Vanek and Jovičić, 1975; Sapir, 1980). Figure 7 demonstrates that labour-managed firms were indeed attempting to maximise income per worker. Real hourly wages divided by the marginal product of labour (MPL) (figure 7.a) and by TFP (figure 7.b) had dramatically increased in Yugoslavia since $1965 .{ }^{17}$ This implies that the governing objective of labour-managed firms raised the wage rate above its market clearing level, preventing households from satisfying their condition for the marginal rate of substitution between consumption and leisure, causing the deterioration of the labour wedge. A similar spike in real wages coincides with the deterioration of the Greek, Portuguese and Spanish labour wedges during the 1970s, corroborating the importance of real wages in driving the evolution of the labour wedge.

The evolution of real wages in Yugoslavia does not appear sufficient in explaining the deterioration of the labour wedge since the late 1970s. Real wages had dramatically declined. Further mechanisms linking the behaviour of the labour-managed firm to the evolution of the labour wedge are required.

The governing objective of labour-managed firms was partially achieved through restricting new labour entry into existing firms (Milenkovitch, 1971; Sapir, 1980). Even though real wages had collapsed during the 1980s, existing workers were able to capture a larger share of the wage bill than it would have been possible if entry of labour into existing labour-managed firms were not restricted. This behaviour resembles insider-outsider models of labour markets characterized by strong trade unions.

The tendency of labour-managed firms to restrict employment is theoretically well grounded (Ward, 1958; Meade, 1972). Allowing free establishment of firms could have alleviated such distortion. This was not possible since the local government decided whether to allow an establishment of a firm within its administrative boundaries (Horvat, 1971). Furthermore,

\footnotetext{
${ }^{17}$ The rationale of dividing wages by the MPL follows from the standard first order condition of the firm of equating wages with the MPL. However, workers in Yugoslav labour-managed were appropriating capital rent, and their income depended partially on the capital to labour ratio (Vanek and Jovičić, 1975). As such, dividing wages by TFP might be a better indicator of the extent to which workers managed to maximise their incomes.
} 
Figure 7: Hourly real wage rates divided by marginal product of labour (MPL) and TFP, Yugoslavia and sample countries
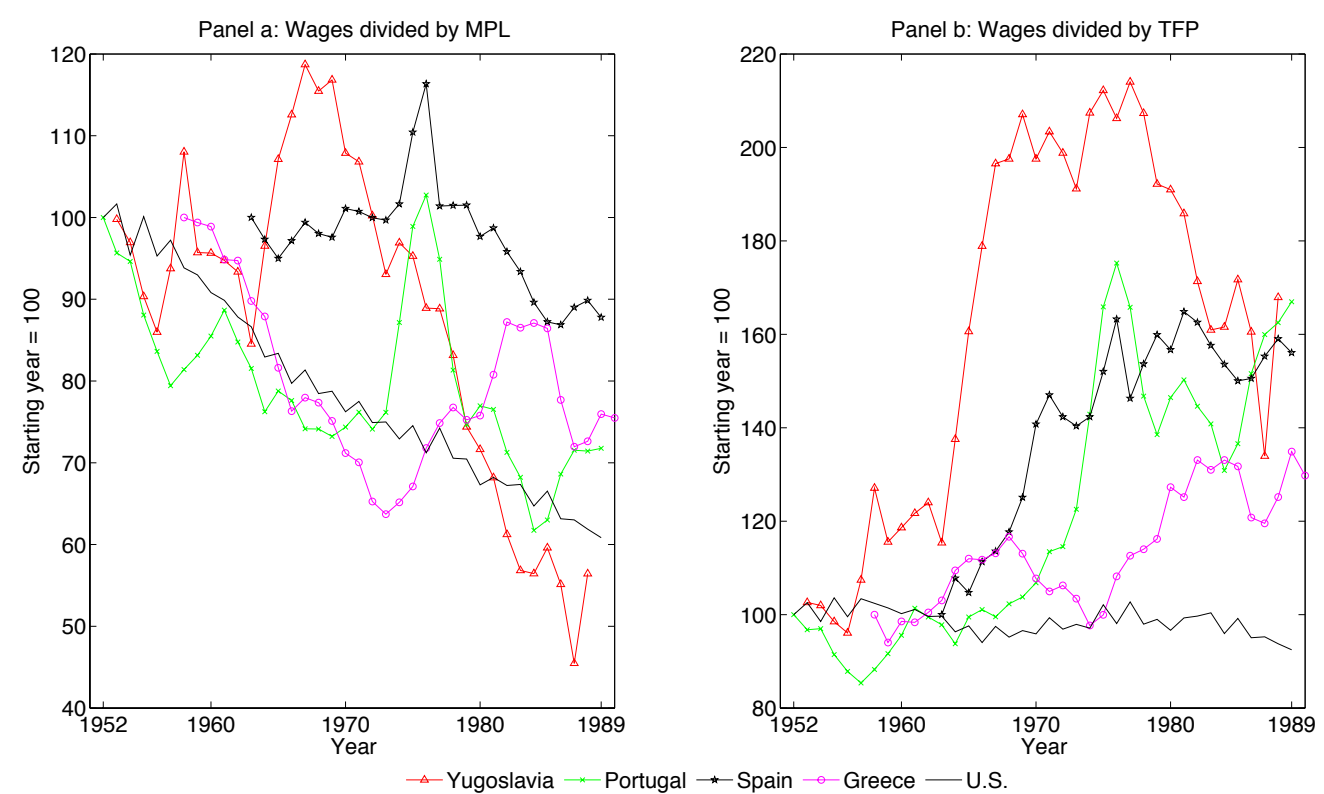

Note: Real wages are wage rates in manufacturing, in order to ensure comparability of series among the sample-countries.

Sources: For Yugoslavia: SGJ (Savezni Zavod za Statistiku, 1952-1991); for Greece, Portugal and Spain: Mitchell (2013); for U.S.: BLS (online).

access to finance was limited (Prout, 1985). Banks were founded and owned by existing firms. It is unlikely that an established firm would be willing to finance a new potential competitor through a proxy.

The restriction of labour mobility is reflected in a sharp decrease in the job separation rate (figure 8.c) and the job finding rate (figure 8.d) in the immediate aftermath of the 1965 reforms. The ability of Yugoslavs to supply labour was severely limited due to the governing objective of labour-managed firms, causing further deterioration of the labour wedge. This was subsequently magnified by the macroeconomic instability instigated by the 1979 oil shock.

The decrease of the job finding rate after 1965 is not immediately reflected in either the actual unemployment rate (figure 8.a) or the natural rate of unemployment (figure 8.b) due to emigration of labour. With the elimination of travel restrictions in 1966, a large fraction of labour moved to West Europe in search for higher wages (about 10 per cent) (Lampe, 2000). This drained the domestic supply of labour, possibly causing further worsening of the labour wedge. To speculate, it is possible that friends and relatives of emigrants that stayed in the country were willing to decrease their labour supply because of the massive influx of remittances. Between 1966 and 1989, remittances could fund, on average, about 15 per cent of the expenditure 
Figure 8: Labour market dynamics in Yugoslavia, 1960-90
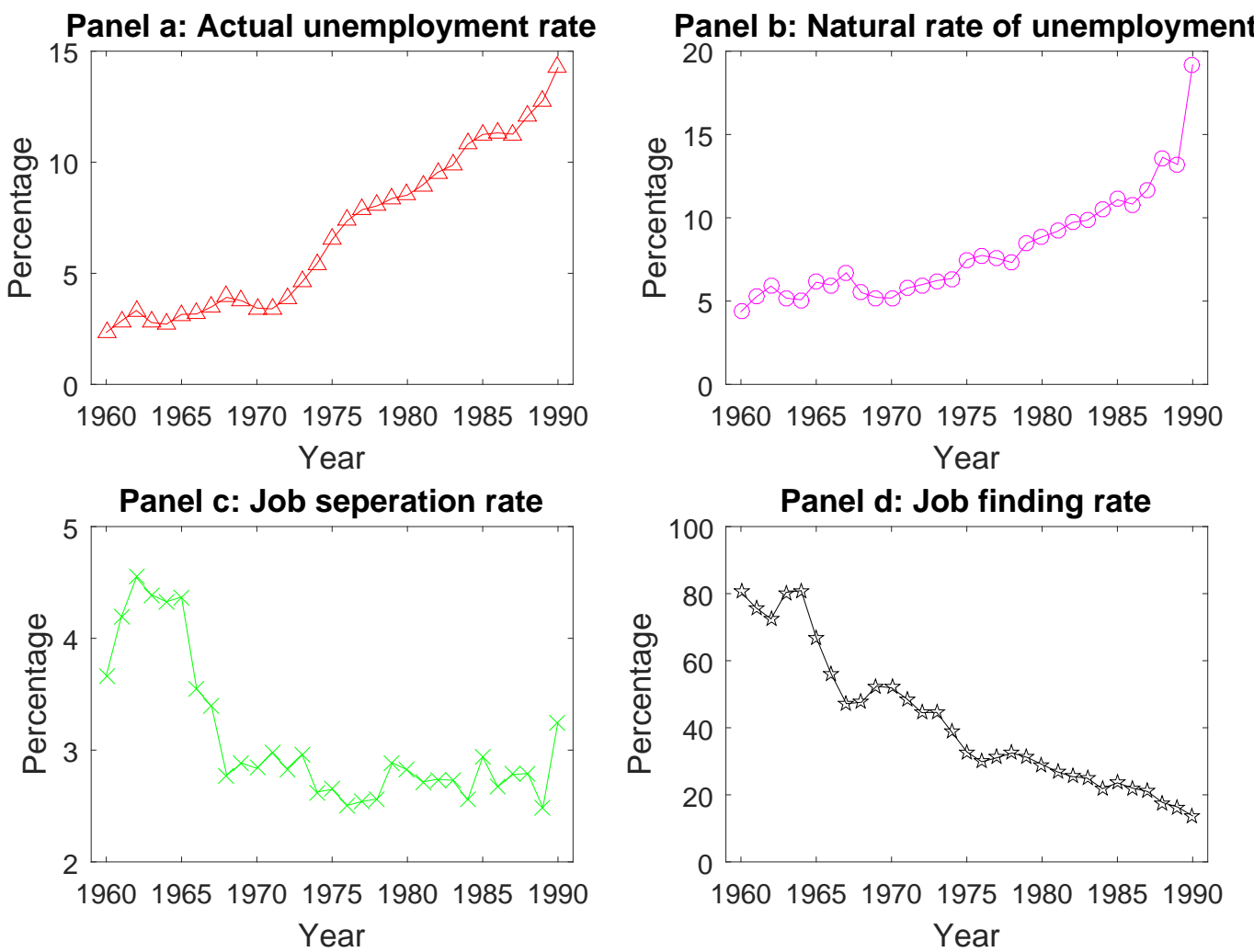

Notes: The data on labour market dynamics prior to 1960 is not available. The natural rate of unemployment $(U)$ is calculated as; $U=\frac{s}{(s+f)}$, where the job separation rate $(s)$ represents the fraction of employed workers who lost their job in a particular year, while the job finding rate $(f)$ represents the fraction of unemployed people who were able to find a job within a particular year. Interestingly, the natural rate of unemployment is higher than actual unemployment rate. This could be due to data issues, but might further indicate disguised unemployment.

Sources: SGJ (Savezni Zavod za Statistiku, 1961-1991).

side of the balance of payments position. ${ }^{18}$

\subsection{Income wedge}

The evolution of the income wedge (figure 3.d), has been shaped by net exports. Net exports have particularly deteriorated during the 1970s, driving the deterioration of the income wedge. In 1969, I find that imports exceeded exports by 1 percentage point of GDP, while in 1979, imports exceeded exports by 7 percentage points of GDP. As the country entered the debt crisis, depressed domestic demand limited imports of both consumer and investment goods. Furthermore, Dyker (1990) argues that imports of both consumer and investment goods were deliberately decreased in order to mitigate a balance of payment crisis. Exports, given constrained foreign demand, were promoted at any cost. Consequently, the current account

\footnotetext{
${ }^{18}$ SGJ (Savezni Zavod za Statistiku, 1967-1990).
} 
Table 5: The contribution of wedges to the growth rate of selected macroeconomic variables in Yugoslavia, 1952-89

\begin{tabular}{|c|c|c|c|c|}
\hline & Output per capita & $\begin{array}{l}\text { Labour } \\
\end{array}$ & Capital to labour ratio & Physical capital \\
\hline \multicolumn{5}{|l|}{$1952-1960$} \\
\hline Average annual Growth rate & 5.4 & -1.3 & 4.6 & 5.0 \\
\hline TFP & $119 \%$ & $408 \%$ & $-28 \%$ & $466 \%$ \\
\hline Capital wedge & $33 \%$ & $-85 \%$ & $33 \%$ & $-6 \%$ \\
\hline Labour wedge & $22 \%$ & $-454 \%$ & $74 \%$ & $-12 \%$ \\
\hline Income wedge & $48 \%$ & $77 \%$ & $37 \%$ & $-98 \%$ \\
\hline \multicolumn{5}{|l|}{$1960-1970$} \\
\hline Average annual Growth rate & 3.1 & -7.1 & 6.2 & 4.2 \\
\hline TFP & $132 \%$ & $-20 \%$ & $71 \%$ & $24 \%$ \\
\hline Capital wedge & $48 \%$ & $7 \%$ & $26 \%$ & $19 \%$ \\
\hline Labour wedge & $6 \%$ & $-127 \%$ & $74 \%$ & $-107 \%$ \\
\hline Income wedge & $71 \%$ & $13 \%$ & $40 \%$ & $119 \%$ \\
\hline \multicolumn{5}{|l|}{$1970-1980$} \\
\hline Average annual Growth rate & 3.5 & -3.6 & 5.5 & -1.4 \\
\hline TFP & $151 \%$ & $31 \%$ & $109 \%$ & $-457 \%$ \\
\hline Capital wedge & $14 \%$ & $-111 \%$ & $18 \%$ & $786 \%$ \\
\hline Labour wedge & $11 \%$ & $-111 \%$ & $36 \%$ & $-129 \%$ \\
\hline Income wedge & $89 \%$ & $108 \%$ & $47 \%$ & $-64 \%$ \\
\hline \multicolumn{5}{|l|}{$1980-1989$} \\
\hline Average annual Growth rate & -1.4 & -2.5 & 1.0 & -12.8 \\
\hline TFP & $-29 \%$ & $-160 \%$ & $490 \%$ & $-95 \%$ \\
\hline Capital wedge & $86 \%$ & $120 \%$ & $-70 \%$ & $82 \%$ \\
\hline Labour wedge & $-64 \%$ & $-164 \%$ & $130 \%$ & $-38 \%$ \\
\hline Income wedge & $36 \%$ & $-64 \%$ & $80 \%$ & $-120 \%$ \\
\hline
\end{tabular}

Notes: The annual growth rates of selected macroeconomic variables is detrended by the labour-augmenting technological progress. The table depicts the share of actual growth of a selected macroeconomic variable a wedge can replicate, conditional on the other wedges remaining fixed.

position of Yugoslavia improved. For the first time in its history, exports exceeded imports by 1983, driving the improvement of the income wedge. ${ }^{19}$ The evolution of the income wedge implies that the external shocks to the Yugoslav economic performance after 1979 were partially positive. They caused a forceful restructuring of the balance of payments position, and the structure of GDP.

\section{Simulation results: The contribution of wedges to economic growth}

\subsection{Baseline results}

From the previous section, it is impossible to assess the quantitative contribution of each wedge to economic growth. Table 5 displays the contribution of wedges to the average annual growth rate of each macroeconomic variable of interest (output per capita, labour, capital to labour ratio, and physical capital). The contribution of each wedge is isolated by holding constant the value of all the remaining wedges to their average 1952-7 levels. The contribution of each wedge reveals how much a variable of interest would have grown solely because of the evolution of that wedge, relative to its realised or actual growth rate.

During the 1950s, TFP growth is able to replicate 119 per cent of realised economic growth (first column of table 5). In the 1960s, the ability of TFP to replicate actual economic growth

\footnotetext{
${ }^{19}$ In 1986 as a record year, exports exceeded imports by 1.6 percentage points of GDP.
} 
increases to 136 per cent, and to 151 per cent during the 1970s. Thus, during these three decades, economic growth would have been higher were all the other wedges fixed. During the 1980s, TFP would have made economic growth negative by a smaller degree were it not for the evolution of the other wedges. The increasing importance of TFP in sustaining economic growth during the Golden Age is reflected in the increasing contribution of TFP to the growth rate of the capital to labour ratio (third column of table 5). TFP increased the steady state level of output, while convergence towards the steady state was facilitated through an increase in the capital to labour ratio.

The capital wedge stimulated growth in each decade, primarily through stimulating the capital to labour ratio. The income wedge stimulated growth strongly during the 1970s and the 1980s through increased net foreign demand for domestically produced goods and services. Increased net foreign demand indirectly stimulated growth through increased demand for labour (column 2 of table 5) and the capital to labour ratio.

The labour wedge was of minor importance in stimulating output between 1950 and 1980, and it drove the retardation of economic performance during the 1980s. Throughout the sample period, the labour wedge was a major constraint on growth through decreasing labour and physical capital (fourth column of table 5).

Segmenting periods is a useful quantitative summary of results, but can obfuscate the dynamic dimension. The remainder of this section seeks to reinforce the two main findings of this paper. First, that TFP became more important over time in sustaining growth. Second, that the labour wedge was the most important constraint on growth.

Figure 9 plots the evolution of output per capita determined by all the wedges except TFP (the line "without TFP"), in relation to the actual evolution of output per capita. The line without TFP depicts simulated economic growth were TFP growth absent. The gap between the two plotted lines is due to TFP.

Figure 9 reveals that in the early stages of growth (approximately until the early 1960s), the path of the actual output and the counterfactual output track each other closely. This means that the combined capital, labour and income wedge are able to replicate most of economic growth. The gap between the two lines widens over time, meaning that TFP became more important in sustaining growth with time.

To gauge further the relative significance of wedges, figure 10 estimates the marginal contribution of each wedge to economic growth. It adds to the prototype model one at a time 
Figure 9: The actual evolution of GDP per capita versus the counterfactual evolution of it (without TFP), 1952-89, Yugoslavia

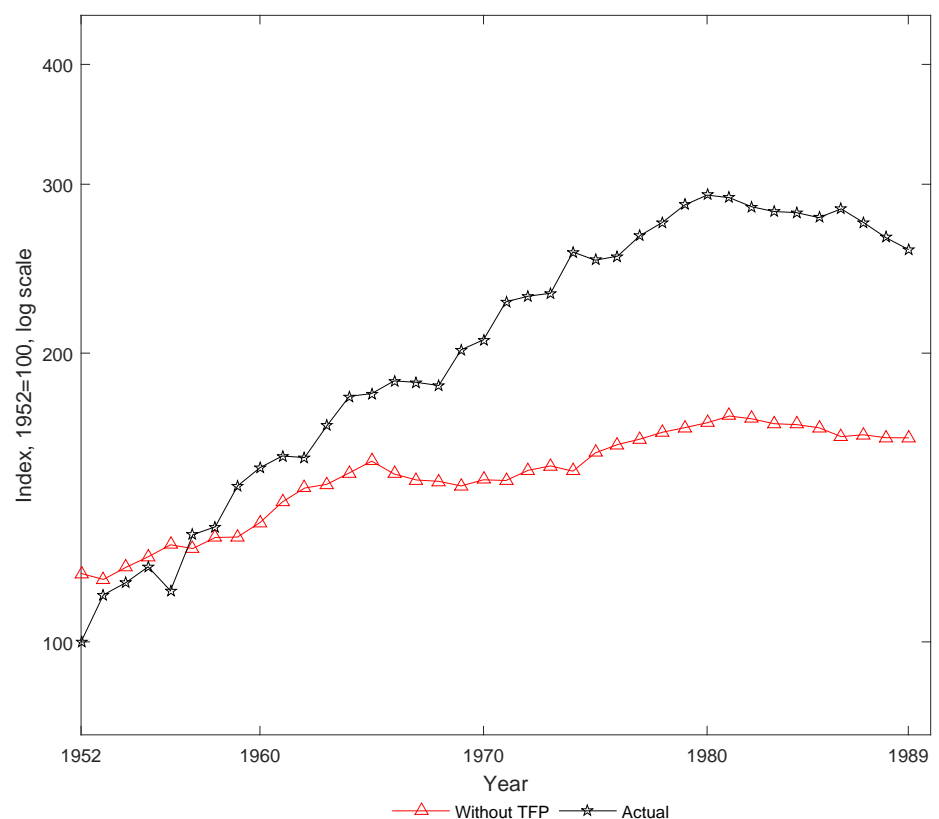

Note: If the two lines move in parallel, it means that the combined capital, labour and income wedges are responsible for most of economic growth.

the capital wedge, TFP, the labour wedge, and the income wedge. The four wedges in tandem match the data (the line "actual"). When the sequential addition of wedges makes the simulated path of economic growth move more in tandem with the actual path of economic growth, the newly added wedge is responsible for that movement.

The model that includes just the capital wedge systematically underestimates economic growth since the late 1950s. Before, it generates a higher level of growth than implied by data. When TFP is added to the model containing the capital wedge, the path of simulated economic growth tracks the actual path closely. Thus, this model reconfirms that TFP became gradually more important in sustaining economic growth. When the labour wedge is added to the model containing the capital wedge and TFP, the simulated path of economic growth is nearly identical to the actual path until 1965. Afterwards, the discrepancy between the actual path of economic growth and the simulated path gradually widens (the discrepancy is due to the remaining income wedge). This reconfirms that the labour wedge was a major constraint on economic growth. The model with the capital wedge and TFP reinforces this finding. It implies a higher level of GDP per capita than the data from the mid-1960s. 
Figure 10: Simulations of GDP per capita versus the actual movement, 1952-89, Yugoslavia

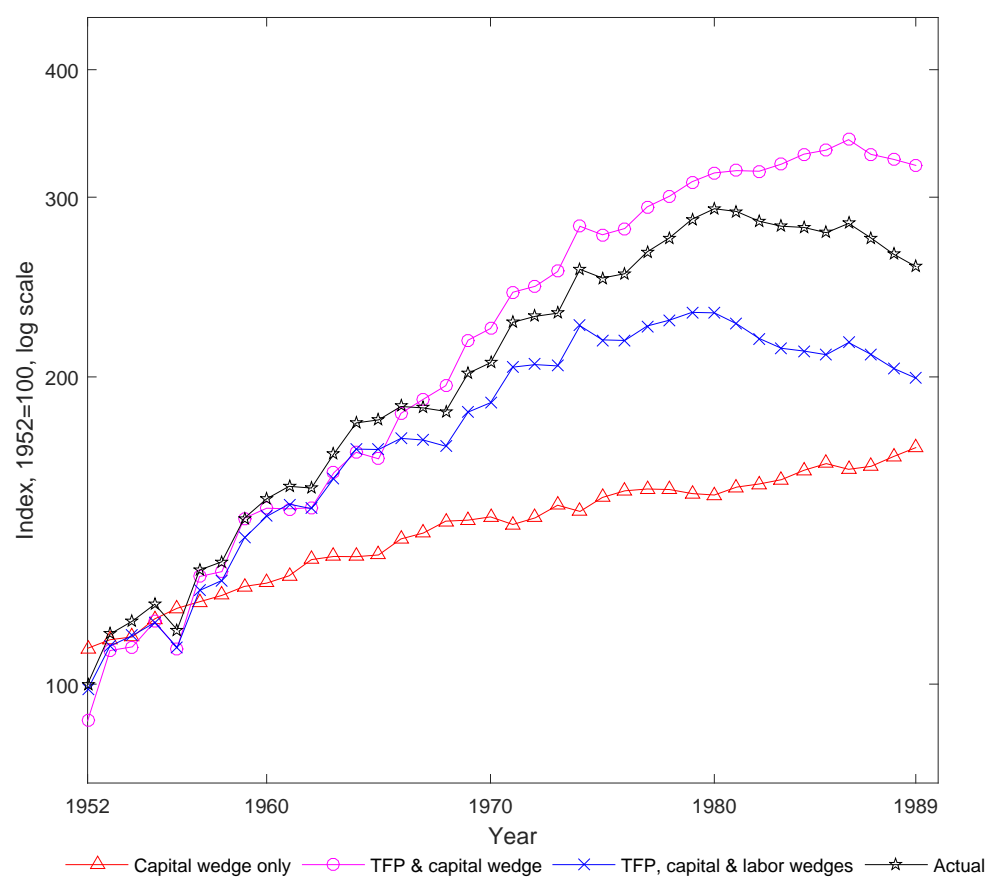

\subsection{Robustness checks}

This section briefly reports the sensitivity of the baseline findings to alternative settings. I reserve a detailed discussion of each robustness check to appendix A.3.

In appendix A.3, I experiment with the choice of parameters (coefficient for leisure, discount factor, capital share, technological growth), functional forms (utility function with linear leisure, and subsistence income), and other settings (exclusion of income wedge, alternative labour data). ${ }^{20}$ The level of wedges can be highly sensitive to the choice of parameters - coefficient for labour and capital share in particular. Other settings do not change the level of wedges significantly compared to the baseline setting. The evolution of wedges, however, which is the cornerstone of the analysis, remains largely unchanged across a variety of settings compared

\footnotetext{
${ }^{20}$ For parameters, I calculate the coefficient for leisure and the discount factor from the data. This exercise yields the coefficient of leisure of 3.5 and the discount factor of 0.95 (identical to the baseline case). Capital share effectively serves as weight on components of growth. To test the sensitivity of my results to the capital share, I push the capital share to a lower and upper bound of plausibility, 0.3 and 0.5, respectively. Assuming a constant growth rate of labour-augmenting technology might be inappropriate for Yugoslavia which experienced growth regime changes. I test the sensitivity of my baseline findings to this parameter by setting it to zero. Concerning functional forms, I experiment with alternative utility functions. I test the sensitivity of my baseline findings to a utility function with linear leisure, which assigns a greater role to labour in driving the fluctuations of macroeconomic variables. I also experiment with the Stone-Geary utility function, which accounts for the presence of subsistence consumption. Concerning other settings, I exclude the income wedge, as it is questionable whether demand shocks have a persistent impact on long-run output. Finally, I smooth average hours worked between the initial year of analysis and the final year of analysis, as the data is characterized by a structural break in average hours worked in 1965, which may or may not be a statistical artefact.
} 
to the baseline setting. In other words, different settings result in different wedge values, but the trends and patterns remain qualitatively unchanged compared to the baseline case. The results of this paper are therefore not driven by the choice of parameter values, functional forms, and other settings. Under a variety of settings, TFP still gradually accounts for a larger share of output growth. Labour wedge remains the main retarding factor of Yugoslavia's economic growth.

\section{Conclusion}

Until the late 1970s, TFP became incrementally more important in sustaining Yugoslavia's economic growth. TFP growth was likely sustained by the accelerated process of structural modernisation; possibly by efficiency gains stemming from the gradual integration of Yugoslavia into the global economy; and possibly by the increased adoption rate of technology. The stagnation of TFP during the 1980s, as well as the stagnation or decline of other macroeconomic variables, is related to the deep crisis instigated by the 1979 oil shock. Even though TFP stagnated, and decreased towards the end of the 1980s, it was of second-order importance in causing Yugoslavia's output retardation. Instead, the deterioration of the labour wedge is the most important factor bringing Yugoslav economy to a stalemate. In turn, intensifying labour distortions were caused by the greater devolution of economic power to labour-managed firms. Yugoslavs were incentivized to undersupply labour domestically. They responded by supplying labour abroad.

In sum, Yugoslav growth retardation has been caused by both internal and external factors. On the internal side, labour-managed firms distorted labour incentives. On the external side, the 1979 oil shock was the main culprit. These results are complementary to the recent work of Vonyó (2017). He argues that the convergence of socialist Eastern Europe towards the income levels of Western Europe was constrained by labour supply inflexibility induced by WWII population loses. It is possible that this labour supply inflexibility interacted with labour-managed firms to distort the ability of Yugoslavs to supply labour.

Given their capacity to embark on radical reforms during the early years, how come Yugoslavs were unable to reform their economy later on? Policy makers were aware of remedies, but politics got into way. Dušan Bilandžić, a historian and a politician, reports in his memoirs that in 1970 the Central Committee of the CPY accepted draft proposals aimed at liberalising 
capital markets and entry of firms (Bilandžić, 2006). The aim of these policies was to diminish or eliminate the apparent labour distortions. However, these policies were abandoned with the flaring of political and ethnic tensions by the 1971 calls for democracy in Croatia, a member republic of Yugoslavia.

The inability of Yugoslavia to cope with the 1979 oil shock was compounded by a major domestic shock. The lifelong president of Yugoslavia, Tito, died in 1980. He was replaced by an ineffectual collective presidency containing nine members. They lacked political capital to pursue planned reforms.

It is natural to wonder whether the findings of this article have wider implications. They do. The recent growth slowdown of China has reinvigorated the debate about the viability of state-led development strategies. The findings of this article can inform this debate. For that matter, Yugoslavia was one of the initial reform models for Chinese policy-makers and their incremental reforms that began in 1978 (Rozman, 2014). The experience of Yugoslavia implies that, in a partially reformed economy, gradual elimination of distortions begets new distortions. Agents that are freed from centralised control respond by exploiting rents in the unreformed parts of the economy. One is left with taking a leap of faith in the omniscience and good intention of planners. 


\section{A Appendix}

\section{A.1 Data: Yugoslavia}

\section{A.1.1 GDP}

Net Material Product, or Social Product (SP) in case of Yugoslavia, was the official metric of output in socialist countries. SP is conceptually equivalent to GDP. Official estimates of the output of socialist economies are however criticised. They are criticized due to index number problems (Gerschenkron, 1947), distorted prices (Staller, 1986), and perhaps outright fabrication by enterprises in order to maximise the allocation of scarce resources within a shortage economy. For these reasons, I use alternative GDP series from Maddison (online). Maddison (online) used the output series created by a group of Western scholars that were published in a series of papers within the Research Project on National Income in East Central Europe, and led by Thad P. Alton from Columbia University. They relied on physical output indicators published in official sources that they transformed into GNP at factor cost. They relied on the method developed by Bergson (1953) to estimate Soviet national income. They imputed the value of output by estimating the returns to factors of production (labour, fixed capital, and agricultural land), and then by multiplying these returns by the volume of factors of production. They consistently applied western national accounting standards (System of National Accounts), making their estimates comparable to output series of market economies. Their publications, covering the whole period under analysis, include Alton (1970) and Alton, Badach, Bass, Bakondi, Brumaru, Bombelles, Lazarcik, and Staller (1992). Their GDP dataset is largely considered to be the most reliable one concerning socialist European countries. It is widely used in empirical research on socialist economies in Europe. For recent examples, see e.g. Vonyó (2017) and Vonyó (2017).

It is worthwhile to note why I am not using the newest collection of GDP estimates by Bolt and van Zanden (2014). They include the GDP estimates of Yugoslav successor states by Branko Milanović. His aim was to produce comparable GDP levels of the successor states of Yugoslavia. He has, however, projected their historical growth rates by official data (information obtained through personal correspondence). Thus, in the Bolt and van Zanden (2014) dataset, the economic growth rates of Yugoslavia are based on official estimates, which are inflated. As such, I prefer to use the earlier Maddison (online) dataset, where growth rates are more reliable.

\section{A.1.2 Gross investment, physical capital stock, and consumption}

The most problematic data required for the analysis is gross investment. Similar to output, gross investment was likely inflated due to price distortions (prices of producer goods were set above world prices, while prices of agricultural goods were set below world prices), index number problems, and perhaps outright fabrication from enterprises. ${ }^{21}$ While alternative output series have been produced in response to the criticism of official output series, there are no existing alternative investment series. As such, I embrace the data produced by government statisticians, but make an adjustment using their own data. As mentioned in the body of the text, I exclude an investment category called "other". I have decided to omit this category since it includes expenditure on product research and training of personnel, which is not part of physical capital. Furthermore, it includes revaluation of inventory stock, while Madžar (1985) reports that, in the presence of high inflation of the 1970 and the 1980s, these values have been inflated.

There are additional factors that distort the investment ratio. The existing literature typically imputes the investment ratio by dividing gross investment by SP. This is a grave mistake that overestimates the investment ratio. Official gross investment includes all the sectors of the economy, while the SP does not. The SP excludes the "non-productive sectors" - education,

\footnotetext{
${ }^{21}$ For example, under controlled prices and resource allocation, investment goods producers had an incentive to increase output by degrading quality. This created the problem of hidden inflation (Bergson, 1987b).
} 
healthcare, culture, administration, housing, and finance. Government statisticians thought these sectors did not contribute to the value-added of a socialist economy. This means, for instance, that the so-constructed investment ratio includes education in the numerator, but not in the denominator. This, naturally, magnifies the investment ratio. To solve this problem, I divide investment by GDP, rather than by SP.

Another common problem in computing the investment ratio is to rely on data expressed in current prices. This is misleading because investment was valued at the end of year, while output was not. This magnifies the so-constructed investment ratio. To solve this valuation problem, I rely on data expressed in constant 1972 prices, before converting it to 1990 Int. GK\$. Contextually, the newly constructed investment series do not seem particularly high, or implausible (figure 2.c).

The initial level of capital stock is estimated using existing national wealth estimates. Vinski (1978) has made a pivotal estimate of national wealth in Yugoslavia. He has used 1953 as the benchmark year. He has relied on an official survey of physical capital in 1953, but extended it to include a much greater array of physical capital. For instance, he estimated the value of residential structures, which the government statisticians ignored. I initially estimate capital stock by type (equipment, residential structures, and non-residential structures) through perpetual inventory method, given the initial value of capital. Subsequently, I aggregate the capital stock types into a single series. Thus, I do not estimate the contribution of each physical capital sub-input to economic growth. In the absence of a capital market, it is not possible to estimate the rental prices of capital sub-inputs with which capital sub-inputs could be otherwise weighted into a single capital aggregate and adjusted for "quality".

In order to derive the level of consumption, I use the official annual consumption to output ratio, and multiply it by Yugoslavia's annual GDP provided by Maddison (online).

\section{A.1.3 Population}

Official data concerning population seems reliable. In the literature on Yugoslavia, or socialist economies more generally, I have not encountered criticism concerning official population data. I take annual estimates of the working-age population (15-64 years) from Vitalna Statistika (1950-4) (Savezni Zavod za Statistiku, 1950-1954) and Demografska Statistika (Savezni Zavod za Statistiku, 1955-1989). Government statisticians have derived these estimates from population censuses, given the fertility and mortality rates. It excludes labour that moved abroad.

Total labour is derived by multiplying the headcount of workers by average hours worked. Yearly hours worked per average worker are defined as effective hours worked, e.g. excluding sick leave but including overtime. These averages are taken from SGJ (Savezni Zavod za Statistiku, 1952-1991).

I take the human capital estimates from Kukić (2017). He estimates human capital for the population that is actually employed, including agricultural labour. He estimates human capital for benchmark years $(1953,1961,1971,1981$, and 1986). For the remaining years of the analysis, I linearly interpolate human capital. For 1987-9, human capital is extrapolated by its average growth rate during 1981-6.

Figure 11 plots population-related data. The sharp decline in the labour to the working age population ratio in figure 2.c in 1965 is driven by the sharp decline in labour (figure 11.a), since the working age population has steadily increased throughout the sample period (figure 11.b). Over the whole period, labour has slightly decreased. This is driven by the decline in average hours worked by 20 per cent during the post-war period (figure 11.c), since the amount of workers has increased by 18 per cent during the sample period (figure 11.d). The decline in average hours worked in 1965 is very sharp. As a robustness check, I assess whether this has an implication concerning the estimated labour wedge in appendix A.3.5. I linearly interpolate hours worked between the initial and final year, so as to smooth the evolution of average hours worked. The baseline findings are unaltered. 
Figure 11: Population data, 1952-89, Yugoslavia
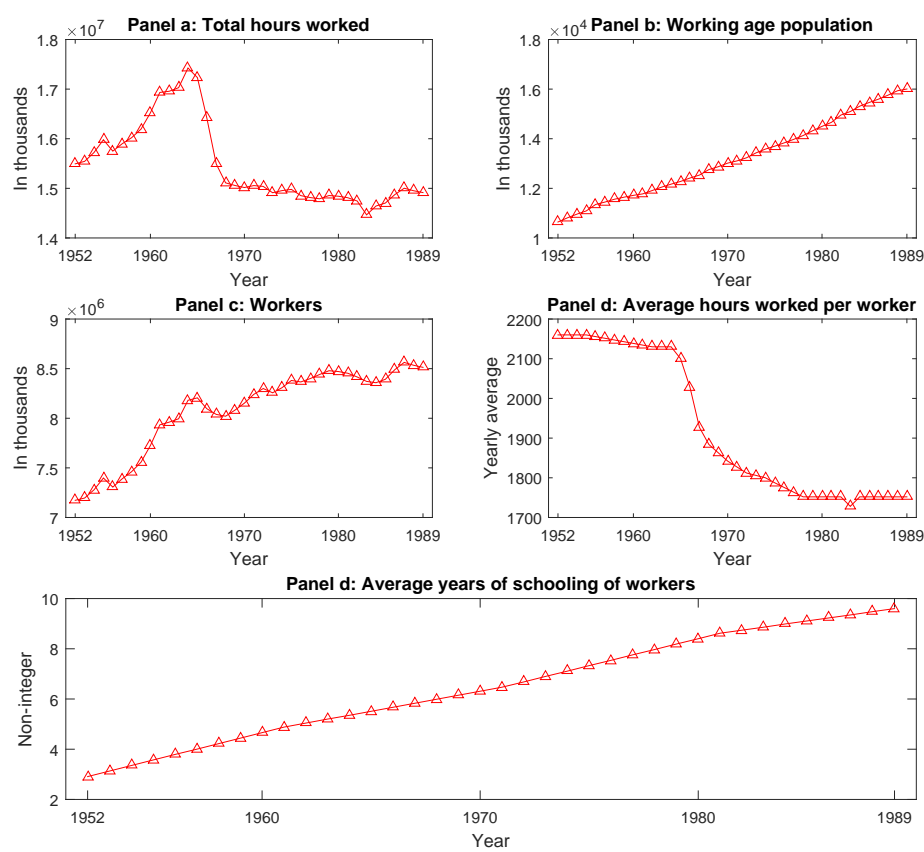

\section{A.2 Data: Greece, Portugal, Spain, and the U.S.}

\section{A.2.1 GDP}

For Greece, Portugal, Spain, and the U.S.: GDP data in 1990 Int. GK\$ is taken from Bolt and van Zanden (2014).

\section{A.2.2 Labour}

For Greece, Portugal, Spain, and the U.S.: Data on the number of workers and average yearly hours worked are taken from the Conference Board (Total Economy Database) (online).

\section{A.2.3 Working-age Population (15-64 years)}

For Greece, Portugal, Spain, and the U.S.: Working-age population is taken from the United Nations (UN) - Department of Economic and Social Affairs (online). The data by the UN is provided in five-year intervals. As such, the in-between years are linearly interpolated.

\section{A.2.4 Human capital average years of schooling}

For Greece, Portugal, Spain, and the U.S.: Data on average years of schooling is taken from Barro and Lee (2013) for the working-age population. Their data is provided at five-year intervals. As such, I linearly interpolate the remaining years.

\section{A.2.5 Consumption, gross investments, and government expenditure}

For Greece, Portugal, and Spain: Consumption and gross investment GDP shares are taken from Penn World Table 8.1 (PWT.8.1) in Feenstra, Inklaar, and Timmer (2015). These shares are subsequently multiplied by Bolt and van Zanden (2014) GDP series to impute the value of consumption and investment in 1990 Int. GK\$. 
For the U.S.: Data is taken from the U.S. Bureau of Economic Analysis (BEA) (online), and deflated into 1990 Int. GK\$ using the official U.S. output deflator.

\section{A.2.6 Physical capital stock}

For Greece: in the absence of long-run national wealth estimates, the physical capital is derived from PWT.8.1 in Feenstra, Inklaar, and Timmer (2015). The capital to output ratio for 1950 is taken from PWT.8.1 and multiplied by the GDP of Greece in Bolt and van Zanden (2014) to impute the value of physical capital stock in 1990 Int. GK\$.

For Portugal: Physical capital stock is derived from Silva and Lains (2013). They initialise their series in 1910 using the steady state approach with 2006 euros. I convert these series into 1990 Int. GK $\$$ through a few steps. First, I derive the capital to output ratio for 2006, where GDP data for 2006 in current prices is taken from Statistics Portugal (online). Second, the capital to output ratio derived is converted into 1990 Int. GK\$ using the GDP series of Bolt and van Zanden (2014). The value of physical capital for the years of the analysis is imputed by applying the real growth rates of physical capital of Silva and Lains (2013) to the capital to output ratio in 1990 Int. GK\$.

For Spain: Physical capital stock is derived from Prados de la Escosura and Rosés (2010). They initialise the physical capital in 1850 using the steady state approach. I multiply their capital to output ratio by the GDP series of Bolt and van Zanden (2014) to derive physical capital in 1990 Int. GK\$.

For U.S.: Physical capital stock is taken from the BEA (online) - fixed assets and consumer durable goods net of government.

\section{A.3 Robustness checks}

\section{A.3.1 Absolute level of wedges of baseline case (figure 3), and general comments}

This section shows the absolute level of wedges of the baseline case (figure 3) in figure 12 . The absolute levels of wedges should be interpreted with caution. Each wedge is calculated relative to the frictionless steady state of the analysed country. Thus, the levels of wedges are conditioned by TFP, investment rate, and the like. As these factors vary among countries, it is very difficult, if not meaningless, to interpret differences in the levels of wedges between countries.

Moreover, as shown in a variety of robustness checks below, the level of wedges can be highly sensitive to the choice of parameters (coefficient for leisure, discount factor, capital share, technological growth) functional forms (utility function with linear leisure, and subsistence income), and other settings (exclusion of income wedge, alternative labour data). The broad evolution of wedges, however, remains largely unchanged compared to the baseline case. In other words, different settings result in different wedge values, but the trends and patterns remain qualitatively unchanged compared to the baseline case. TFP still gradually accounts for a larger share of output. Labor wedge remains the main retarding factor of Yugoslavia's growth.

Each robustness check below reports the relative and absolute level of wedges. Then, each robustness check assesses the sensitivity of the baseline simulation results to different settings by replicating figures 9 and 10 of the main text.

\section{A.3.2 Country-specific coefficient for leisure and discount factor}

This robustness check constructs $\beta$ and $\phi$ from the data for each sample-country. If the results are similar to the baseline case, then the baseline choice of these two parameters is not driving the results of the paper. 
Figure 12: Yugoslav and sample-countries wedges, absolute levels, baseline case, 1952-89
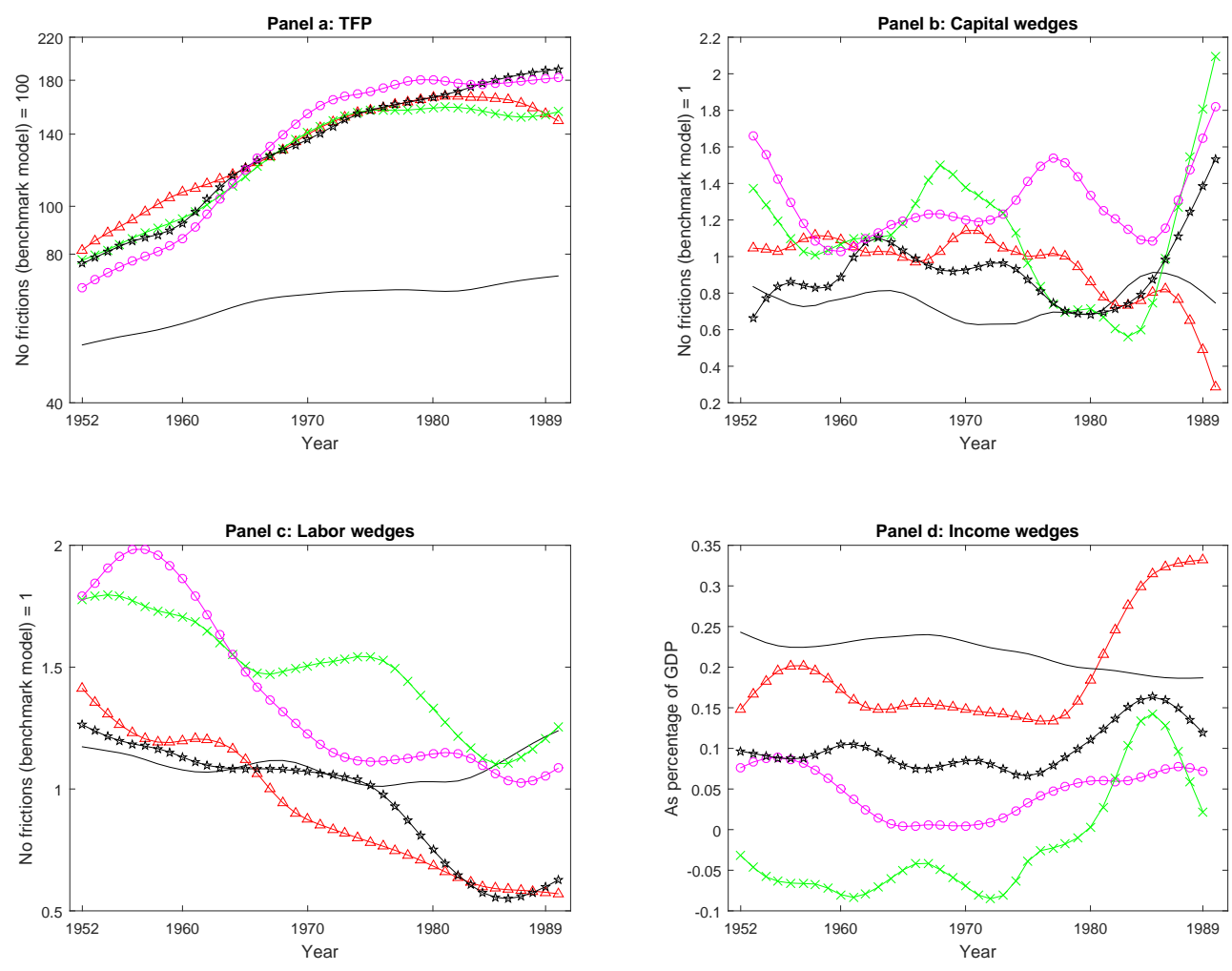

To estimate $\phi$ for each sample-country, labour wedge is assumed to be equal to 1 in equation 8 for 1990, the terminating period. If so, then:

$$
\phi=\left(1-l_{1990}\right) \frac{(1-\theta) \frac{y_{1990}}{l_{1990}}}{c_{1990}}
$$

This exercise yields: Yugoslav $\phi: 3.5$; Greek $\phi: 1.8$; Portuguese $\phi$ : 1.6; Spanish $\phi$ : 3.1; U.S.: $\phi$ : 1.6 .

Similar to the coefficient for leisure, to estimate $\beta$ from the data, the capital wedge is assumed to be equal to 1 in equation 9 for year 1990, the terminating period. If so, then:

$$
\beta=\frac{1+\gamma}{1+\theta \frac{y_{1990}}{k_{1990}}-\delta}
$$

This exercise yields: Yugoslav $\beta$ : 0.95; Greek $\beta$ : 0.98; Portuguese $\beta$ : 0.94; Spanish $\beta$ : 0.94; U.S. $\beta$ : 0.90 .

Figure 13 plots the wedges as in the baseline case of figure 3 . The discount factor and the coefficient for leisure affect the levels of wedges, particularly the labour wedge (figure 14), but not the evolution of wedges. Thus as mentioned before, it makes more sense to interpret trends rather than levels. Since the analysis of the growth rates is the cornerstone of the analysis, the baseline results remain robust.

Figures 15 and 16 replicate the simulation exercises of the baseline case, but using the newly estimated parameters. Figures 15 and 16 are indistinguishable from figures 9 and 10 of the baseline case. 
Figure 13: Yugoslav and sample-countries wedges, relative levels, country-specific coefficient for leisure and discount factor, 1952-89
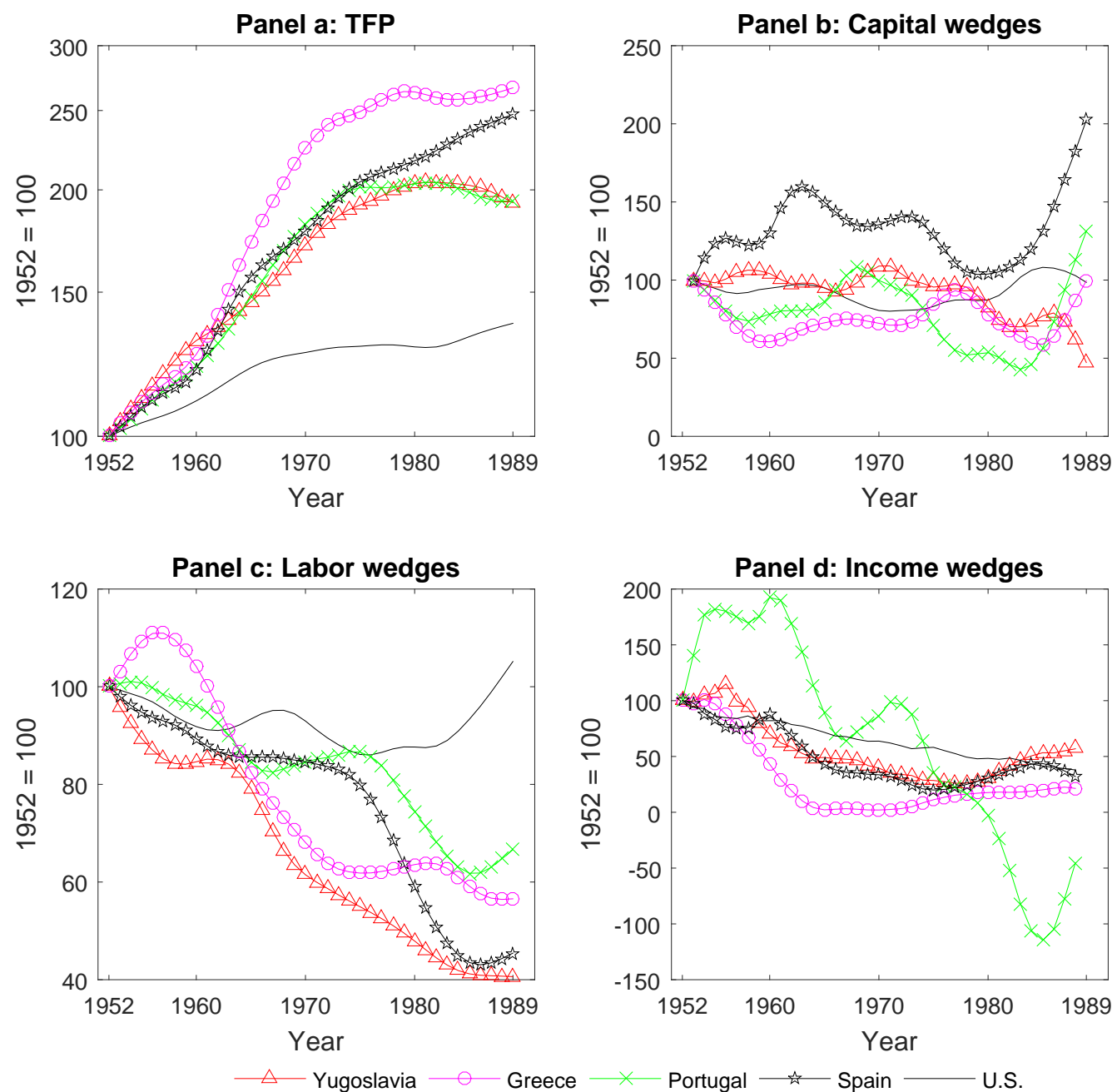

\section{A.3.3 Utility function with linear leisure}

In order to assess the sensitivity of the findings of this paper (labour wedge in particular) to the choice of the baseline utility function, I use an alternative utility function with linear leisure. That is:

$$
\sum_{t=0}^{\infty} \beta^{t} N_{t}\left[\log \left(c_{t}\right)+\phi\left(1-l_{t}\right)\right]
$$

This utility function assigns a greater role to labour in driving the fluctuations of macroeconomic variables.

Figure 17 plots the wedges as in the baseline case of figure 3. Introduction of linear leisure affects the level of the labour wedges (figure 18), but not its evolution. Hence, the baseline results for Yugoslavia remain robust.

Figures 19 and 20 replicate the simulation exercises of the baseline case, but using the utility function with linear leisure. The results remain robust. Figures 19 and 20 seem identical to figures 9 and 10 of the baseline case. However, the simulated output paths seem to fluctuate to a larger extent, reflecting the greater weight assigned to the fluctuations of labour. 
Figure 14: Yugoslav and sample-countries wedges, absolute levels, country-specific coefficient for leisure and discount factor, 1952-89
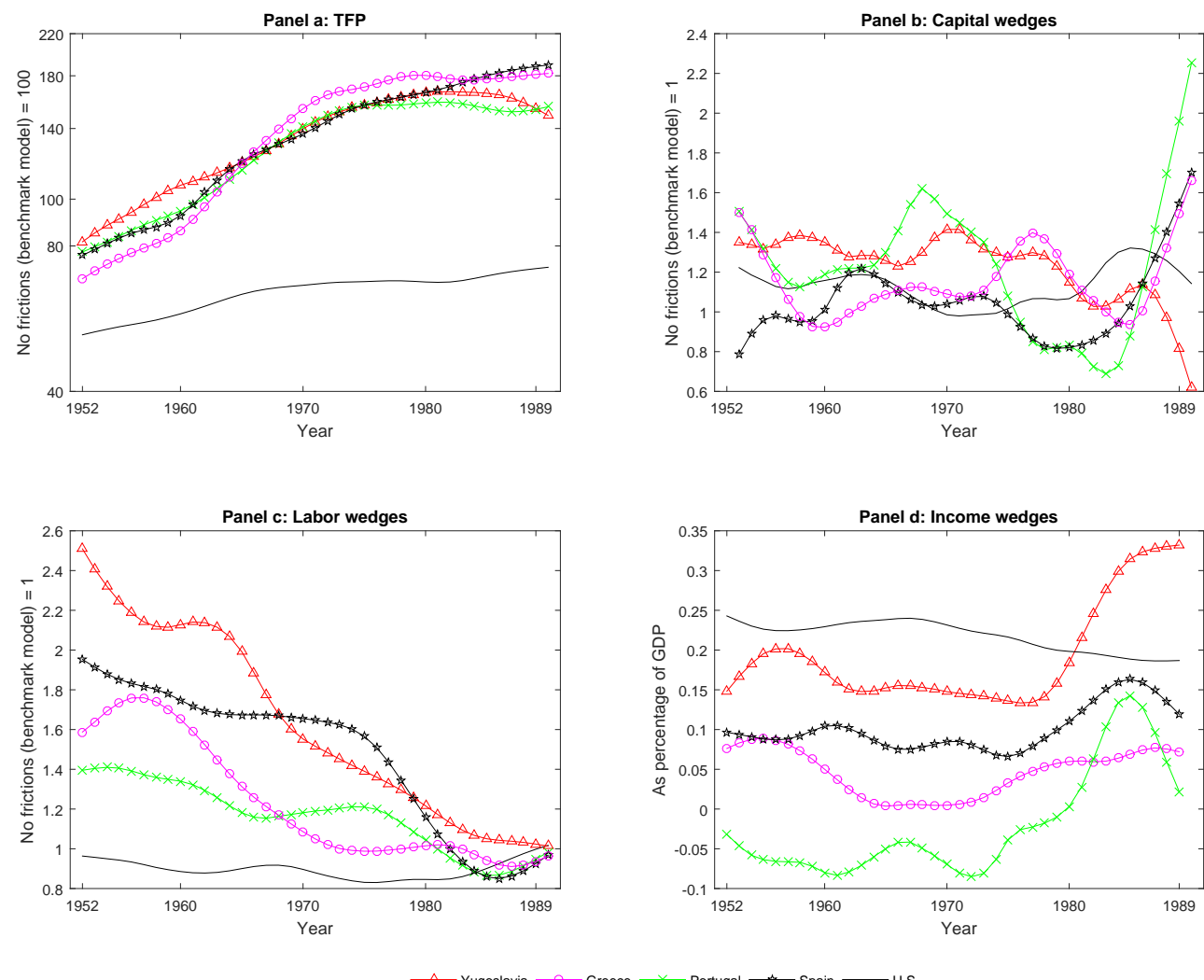

Figure 15: The actual evolution of GDP per capita versus the counterfactual evolution of it (without TFP), country-specific coefficient for leisure and discount factor, 1952-89

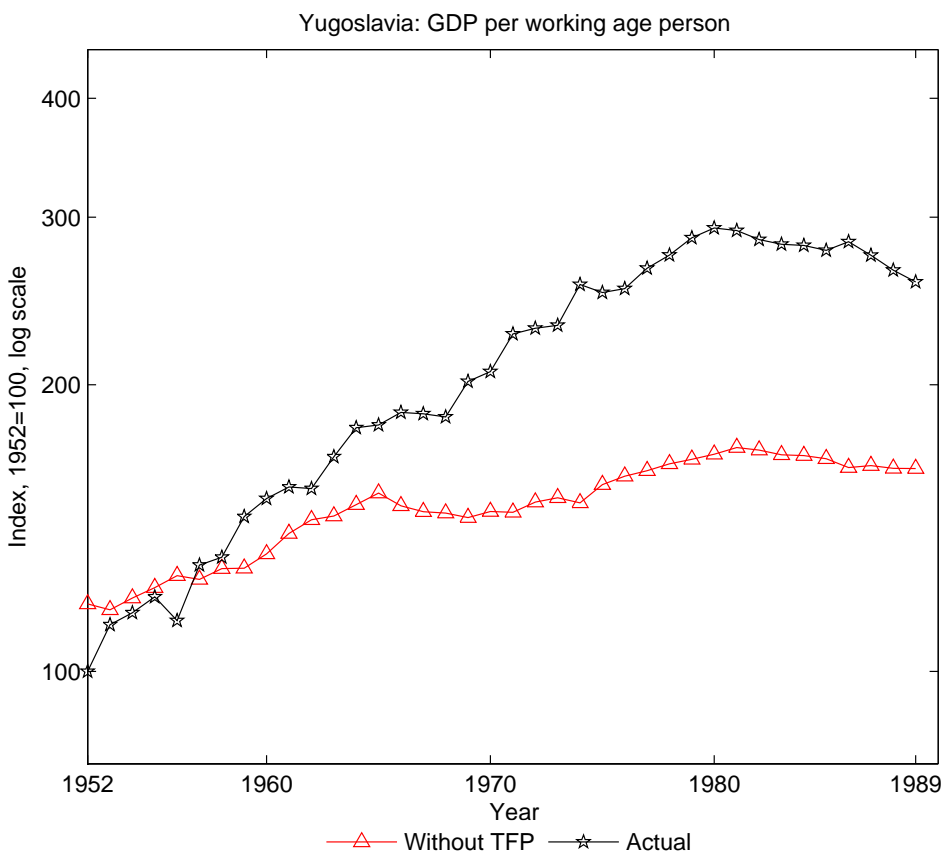


Figure 16: Simulations of GDP per capita versus the actual GDP per capita, country-specific coefficient for leisure and discount factor, 1952-89

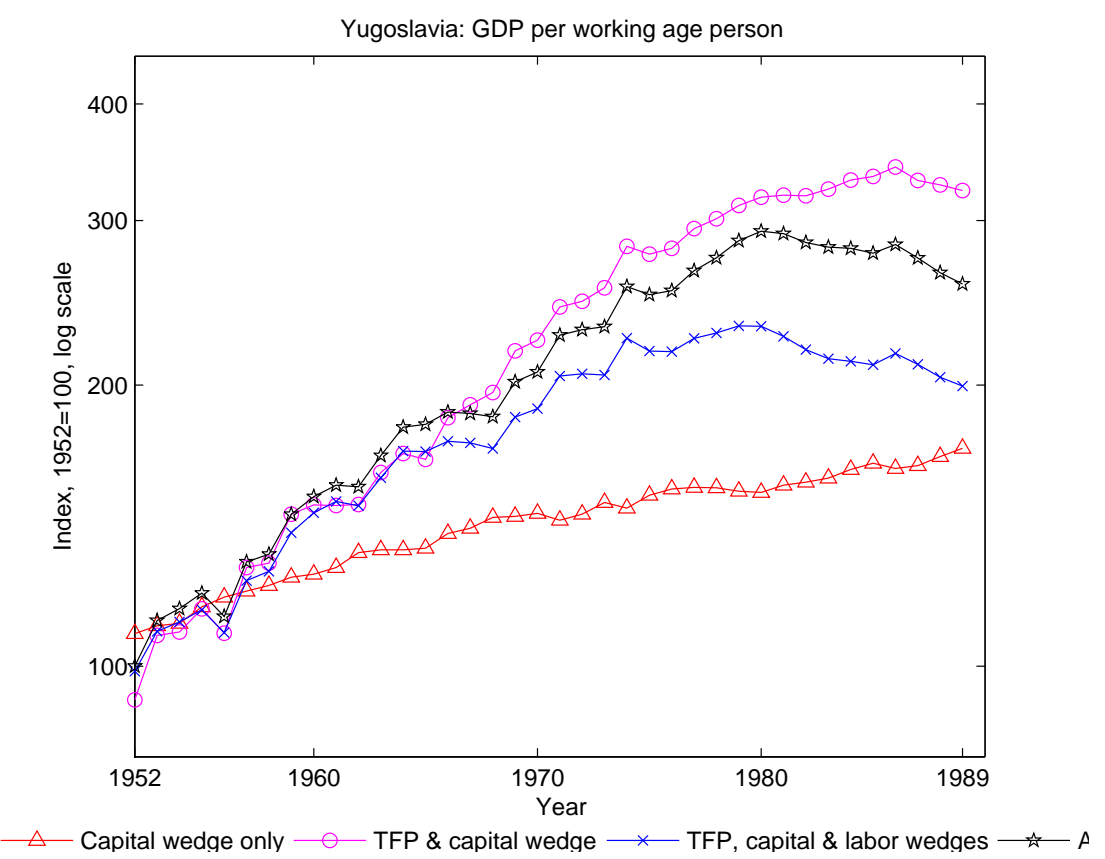

\section{A.3.4 Stone-Geary utility function}

The existence of subsistence income levels might affect the estimated wedges. In developing countries, due to subsistence levels, individuals might in effect have less choice in the allocation of time between work (consumption) and leisure. Subsistence needs might exhaust a large share of their household expenditure. To deal with this issue, I use the Stone-Geary utility function:

$$
\sum_{t=0}^{\infty} \beta^{t} N_{t}\left[\log \left(c_{t}-\bar{c}_{t}\right)+\phi \log \left(1-l_{t}\right)\right]
$$

where $\overline{c_{t}}$ denotes subsistence level, which is fixed. In order to estimate the subsistence level from the data, I assume the labour wedge is equal to one in the first five years of the analysis, thus:

$$
\overline{c_{t}}=c_{t}-\frac{\left((1-\theta) \frac{y_{t}}{l_{t}}\right)\left(1-l_{t}\right)}{\phi}
$$

Figure 21 displays the wedges. Compared to the baseline case of figure 3, the labour wedges tend to be more stable in the beginning of the sample. For Yugoslavia, the initial decline of the labour wedge in the 1950s is quite small. Thus, the existence of subsistence income can explain the initial decline of the labour wedge, which reinforces one of the main conclusions of this paper that the Yugoslav labour wedge embarked on a steady decline since 1965.

However, inclusion of subsistence levels changes the dynamics of the labour wedge in Greece and Portugal quite a bit. In case of Greece, the decline of the labour wedge since the late 1950s is much smoother, while the Portuguese labour seems to have actually improved between the start of the sample-period and the mid-1970s, before experiencing a sharp decline. As expected, the U.S. labour wedge is not impacted by the existence of subsistence levels..

Figures 23 and 24 replicate the simulation exercises of the baseline case, but using the Stone-Geary utility function. The baseline results concerning Yugoslavia remain robust. 
Figure 17: Yugoslav and sample-countries wedges, relative levels, utility function with linear leisure, 1952-89
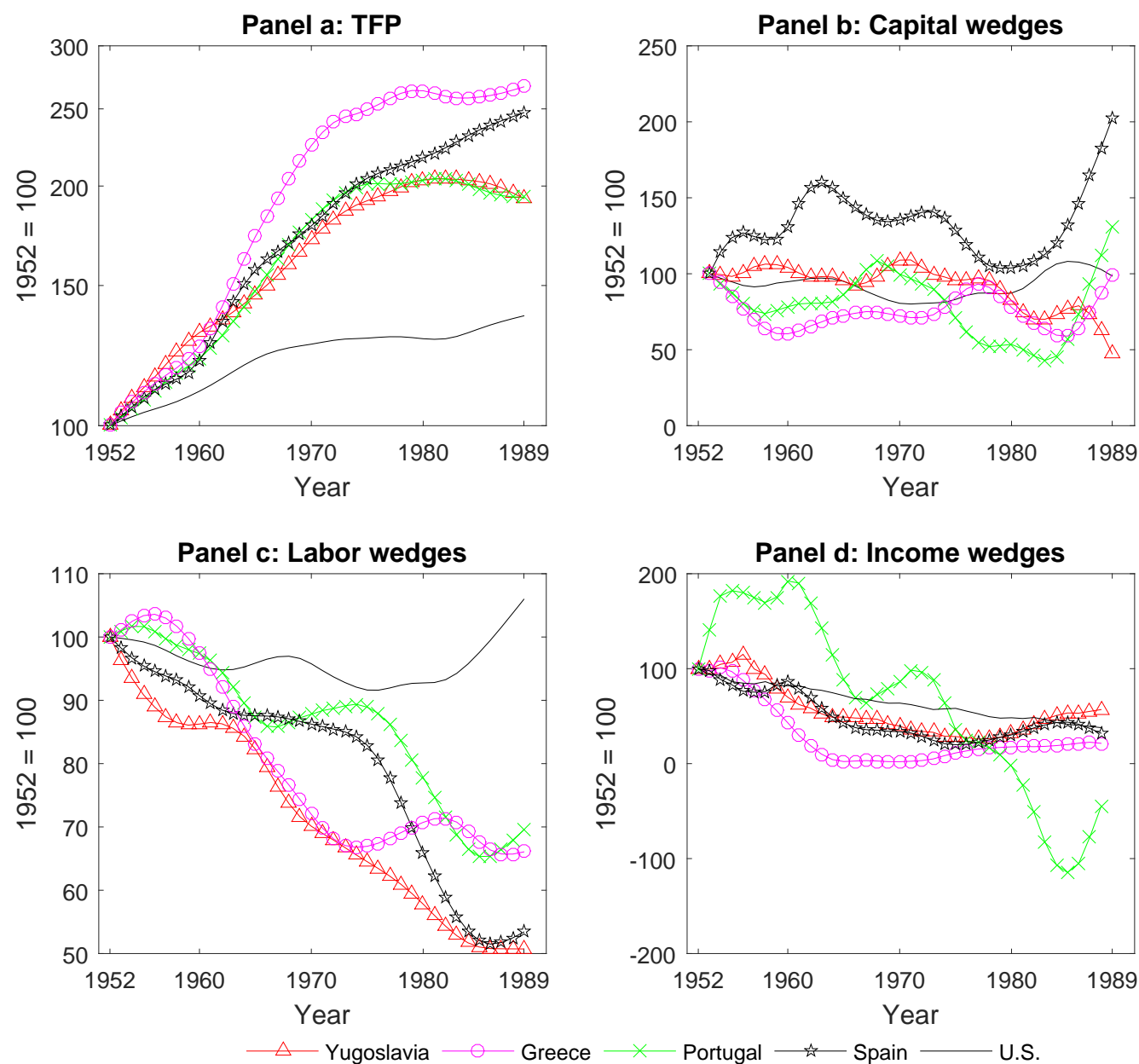

\section{A.3.5 Alternative labour data: linearly interpolated average yearly hours worked}

Here I assess the sensitivity of the labour wedge to average hours worked. Hours worked embarked on a sharp downward trend since 1965, which might be a statistical artefact. To assess the sensitivity of the results to this movement, I smooth the Yugoslav average hours worked by linearly interpolating them between the initial year of the analysis, 1952, and the final year of the analysis, 1989. I do not change hours worked for other sample countries.

Figure 25 presents the wedges. Compared to the baseline case, the decline in the labour wedge is less sharp since 1965, but is still pronounced and steady. The initial level of wedges is identical to the baseline case (figure 26).

Figures 27 and 28 replicate the simulation exercises of the baseline case but using linearly interpolated hours. The sharp decline in average yearly hours worked since 1965 does not seem to have a substantial bearing concerning the baseline findings.

\section{A.3.6 Without income wedge}

The income wedge measures demand "shocks". It is questionable whether demand has a persistent impact on long-run output. Furthermore, the income wedge, or at least components of it, is likely endogenous to the other wedges. Here I exclude the income wedge, and assess whether my baseline findings remain robust. 
Figure 18: Yugoslav and sample-countries wedges, absolute levels, utility function with linear leisure, 1952-89
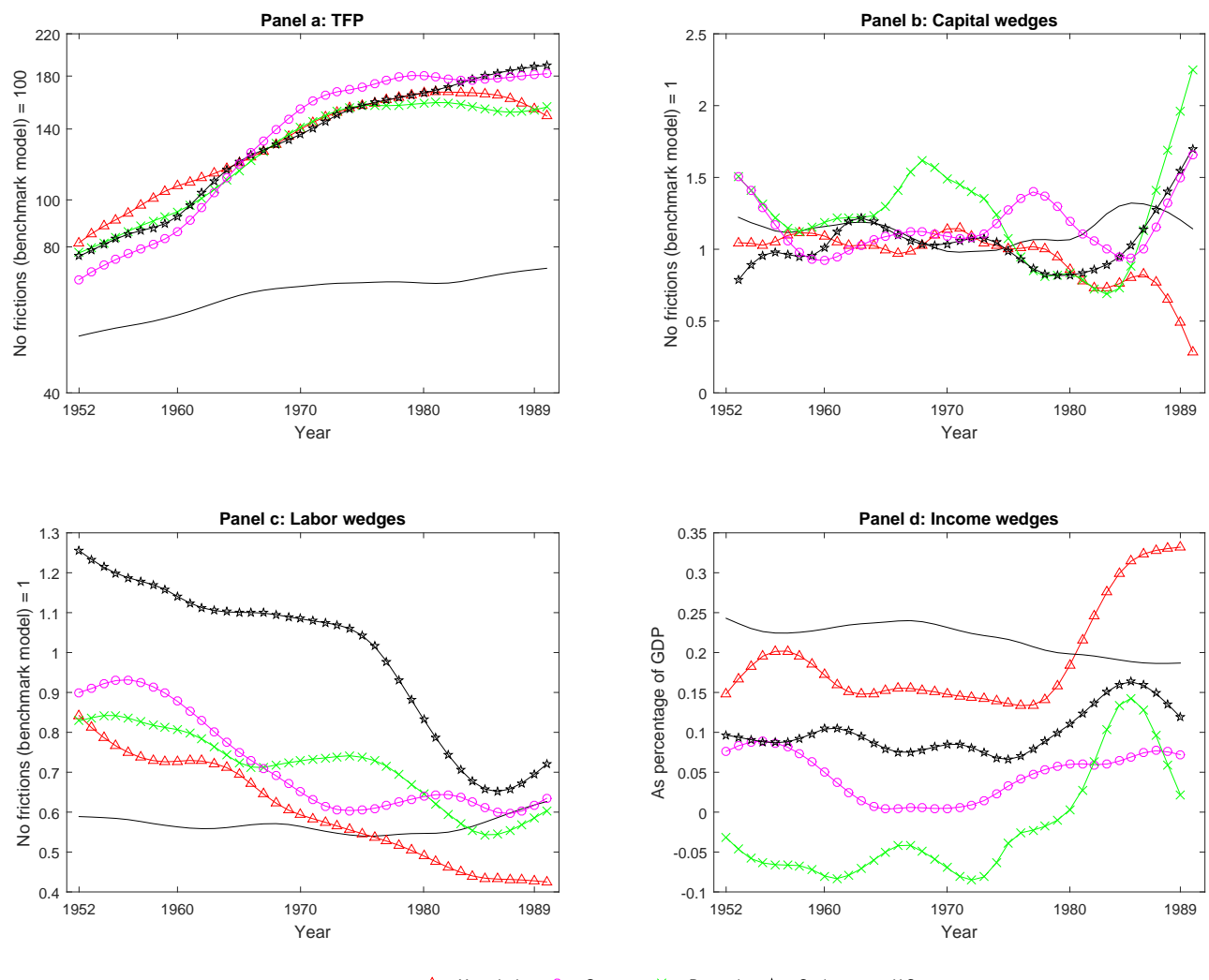

Figure 19: The actual evolution of GDP per capita versus the counterfactual evolution of it (without TFP), utility function with linear leisure, 1952-89

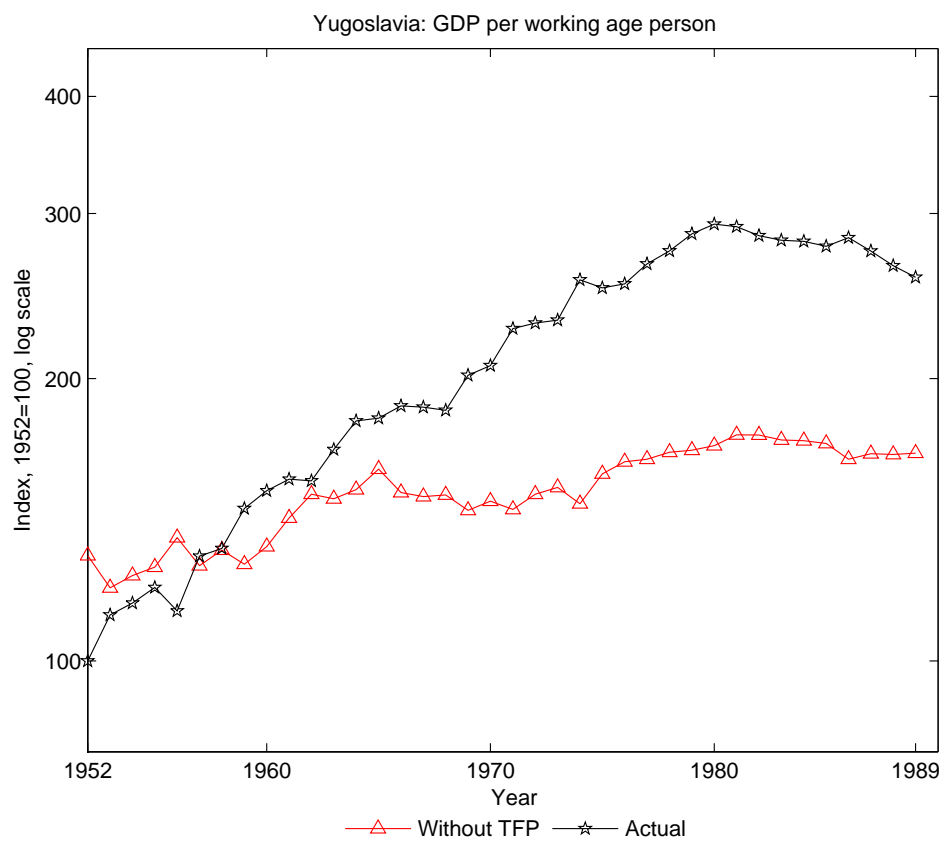


Figure 20: Simulations of GDP per capita versus the actual GDP per capita, utility function with linear leisure, 1952-89

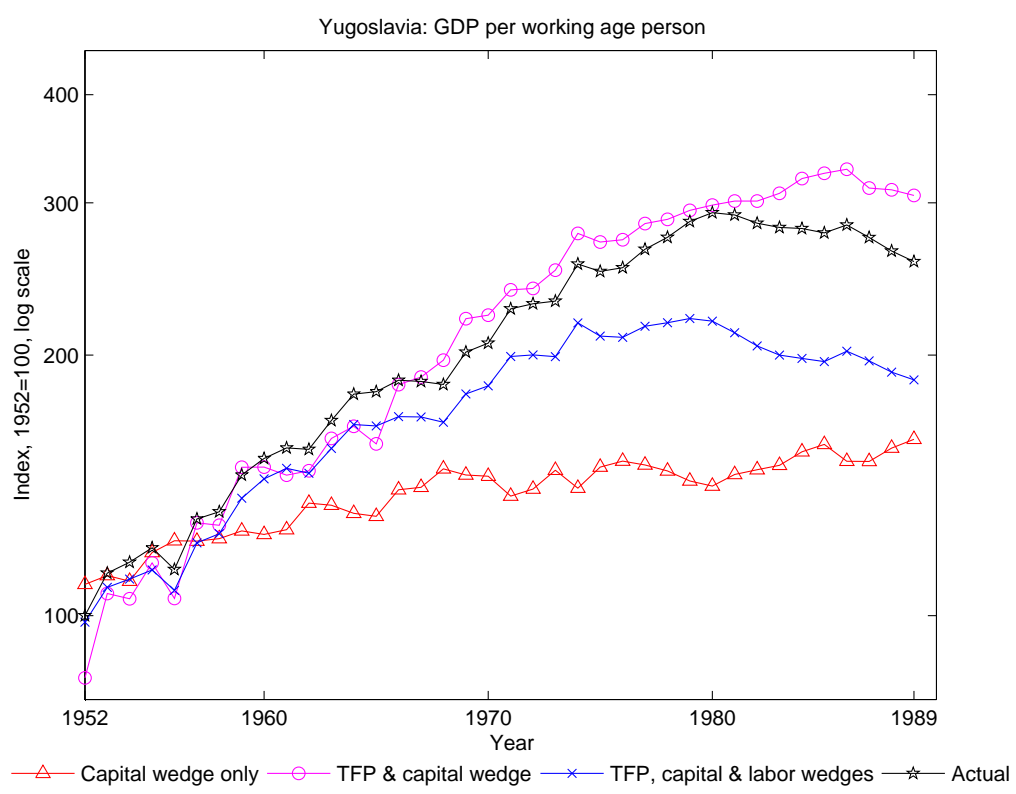

Figure 29 depicts the evolution of wedges, without the income wedge. Figures 31 and 32 recreate the simulation exercises of the baseline case. The initial level of the labor wedge decreases compared to the baseline case (figure 30). In figure 31 the contribution of TFP is much greater than in the baseline case. Without the income wedge, the labour wedge is counteracting the positive contribution of the capital wedge to economic growth (the line "without TFP" in graph 31).

From figure 32 it is hard to determine the impact of the labour wedge on growth. To visualize the contribution of the labour wedge more explicitly, in figure $33 \mathrm{I}$ isolate the contribution of each wedge to growth by holding the other wedges fixed. Figure 33 makes it clear that the labour wedge remains the major constraint on growth with the exclusion of the income wedge. If all the other wedges remained fixed, labour wedge would have made GDP per capita only barely higher at the end of the period, compared to the beginning of the period. Thus, the baseline results remain robust to the exclusion of the income wedge.

\section{A.3.7 Without trend growth rate of labour-augmenting technology}

Because I have included the trend growth rate of labour-augmenting technological progress in the simulation exercises, the baseline model focuses on accounting for fluctuations of economic growth around its trend. That is, it makes a distinction between a balanced-growth path, and the accelerations or decelerations of growth around that path. Since Yugoslavia experienced growth regime changes, assuming a constant growth rate of technology might be inappropriate.

As a robustness check, I exclude the trend growth rate, and assess the sensitivity of the baseline results. I do not show the evolution of wedges here since the baseline case already excluded the trend growth rate of technology, in order to make TFP comparable to standard growth accounting exercises. Figures 34 and 35 recreate the simulation exercises of the baseline case, but setting the trend growth rate of technology to zero. Note that the evolution of wedges in both figures is similar to the baseline case. However, TFP of this section seems to account for a larger share of growth than in the baseline case. Note also that since macroeconomic variables are no longer detrended by a constant rate of technological gains, the actual growth rate of GDP per capita is also higher than in the baseline case. 
Figure 21: Yugoslav and sample-countries wedges, relative levels, Stone-Geary utility function, $1952-89$
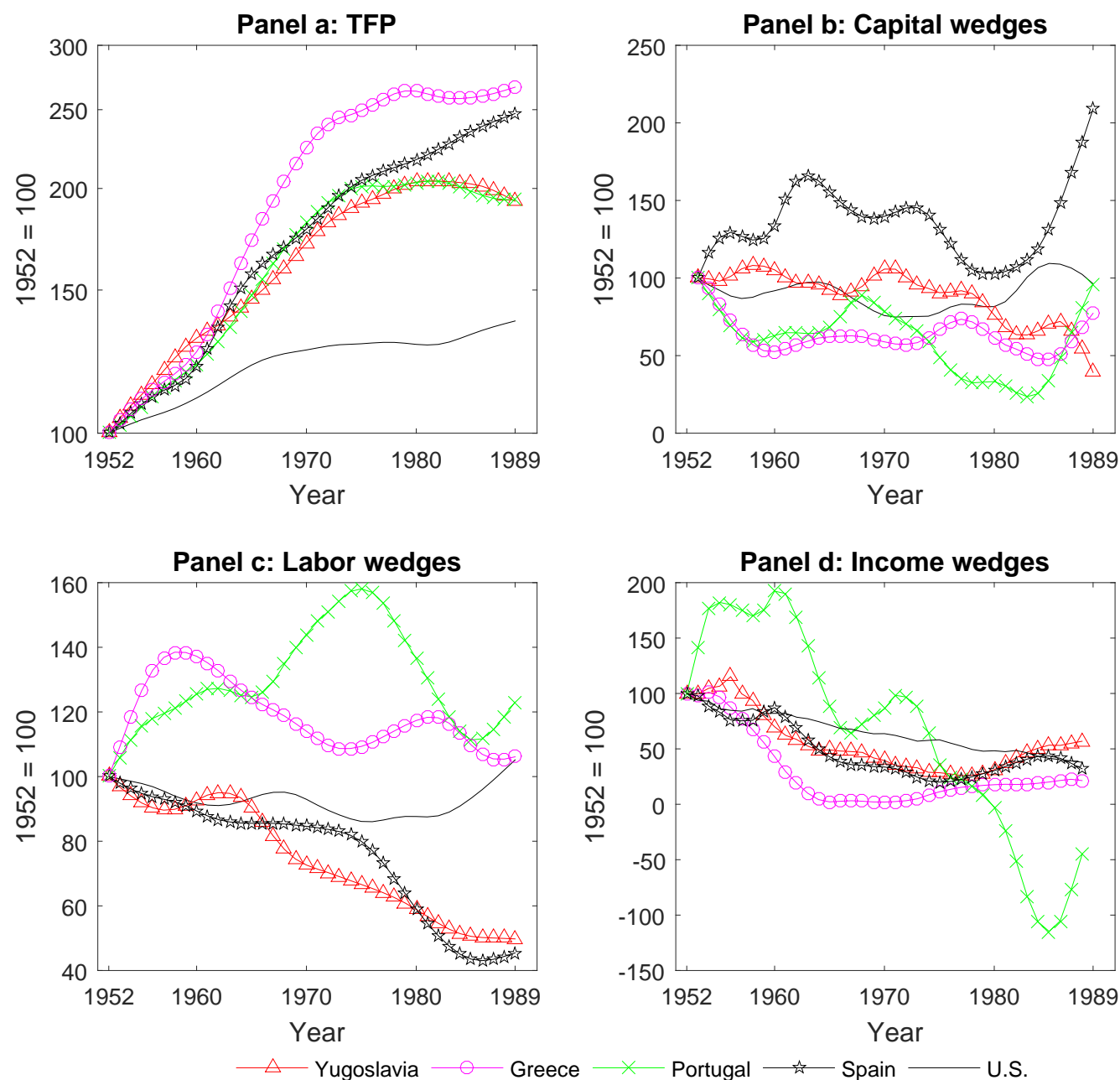

\section{A.3.8 Capital shares}

The capital share is a critical component determining the percentage contributions of physical and human capital to growth. Therefore, I examine how different values of capital share affect the results of this paper. I change the capital share only for Yugoslavia.

I examine two scenarios. I push the capital share to a lower and an upper bound of plausibility (0.3 and 0.5). Then, I assess whether these exercises can overturn the results of the paper. These exercises clearly have a bearing on the proportion of output explicable by TFP. But, the main result concerning TFP remains robust. TFP gradually accounted for a larger share of output, and did not drive the growth retardation of the 1980s.

\section{A.3.8.1 Capital share: 0.3}

In this section, I decrease the capital share to a lower bound of plausibility, 0.3. Figure 36 depicts the new trend of wedges, while figure 37 depicts the new level of wedges. TFP growth rate is now higher. The level of TFP is higher, too. Therefore, decreasing the capital share of output increases both the share of output growth and the level of output that can be attributed to TFP. This reinforces one of the finding of the paper that TFP did not drive the retardation of Yugoslav growth. 
Figure 22: Yugoslav and sample-countries wedges, absolute levels, Stone-Geary utility function, 1952-89
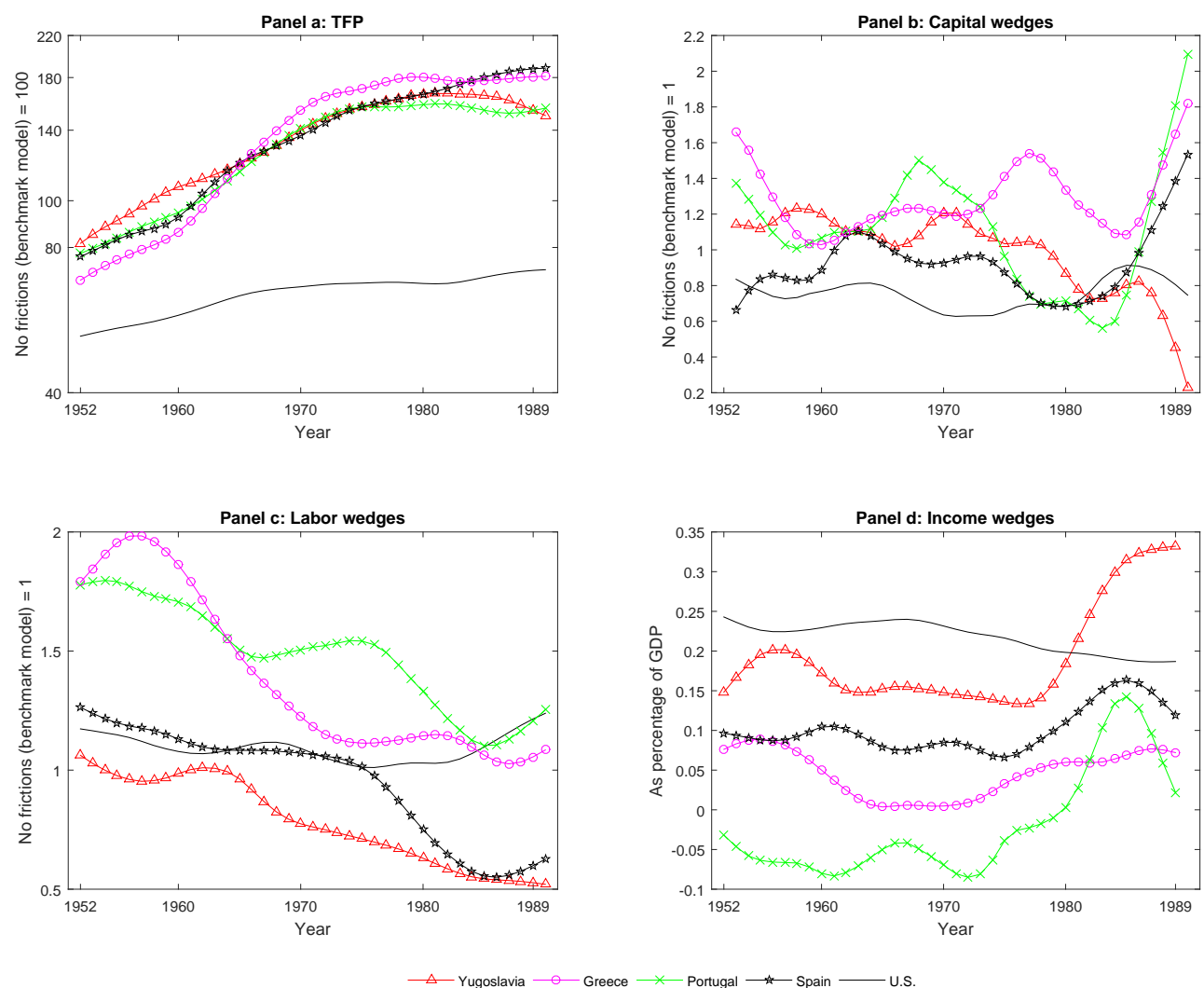

But, it is unclear whether decreasing the capital share has a bearing on the finding that TFP gradually accounted for a larger fraction of economic growth. Figure 38 and 39 show that TFP still gradually accounts for a larger fraction of economic growth when using a lower capital share. However, it seems that with a lower capital share, the fall of TFP towards the end of the 1980s is more pronounced compared to the baseline case.

\section{A.3.8.2 Capital share: 0.5}

In this section, I push the capital share to the upper range of plausibility, 0.5. Figure 40 depicts the new trend of wedges, while figure 41 depicts the new level of wedges. Increasing the capital share reduces the share of output growth than can be attributed to TFP (figure 40). It also decreases the level of output that can be attributed to TFP (figure 41). This does not overturn the main results of the paper. TFP still gradually accounts for a larger fraction of output growth over time (figures 42 and 43). 
Figure 23: The actual evolution of GDP per capita versus the counterfactual evolution of it (without TFP), Stone-Geary utility function, 1952-89

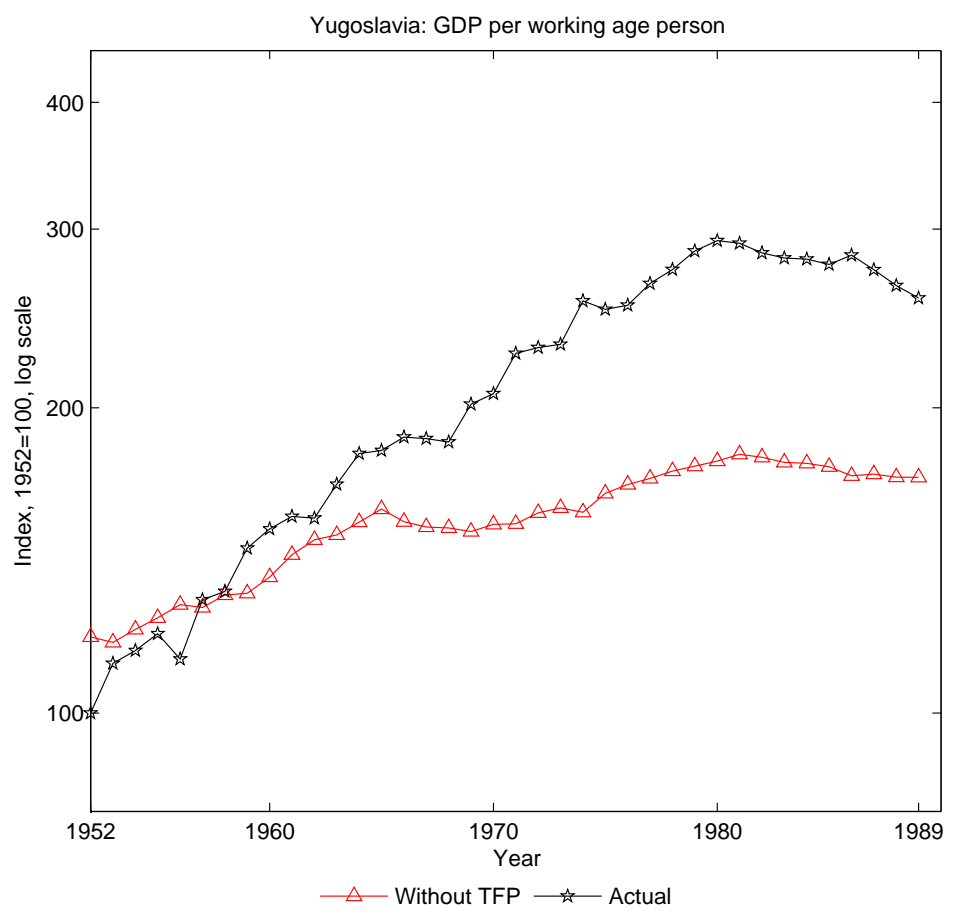

Figure 24: Simulations of GDP per capita versus the actual GDP per capita, Stone-Geary utility function, 1952-89

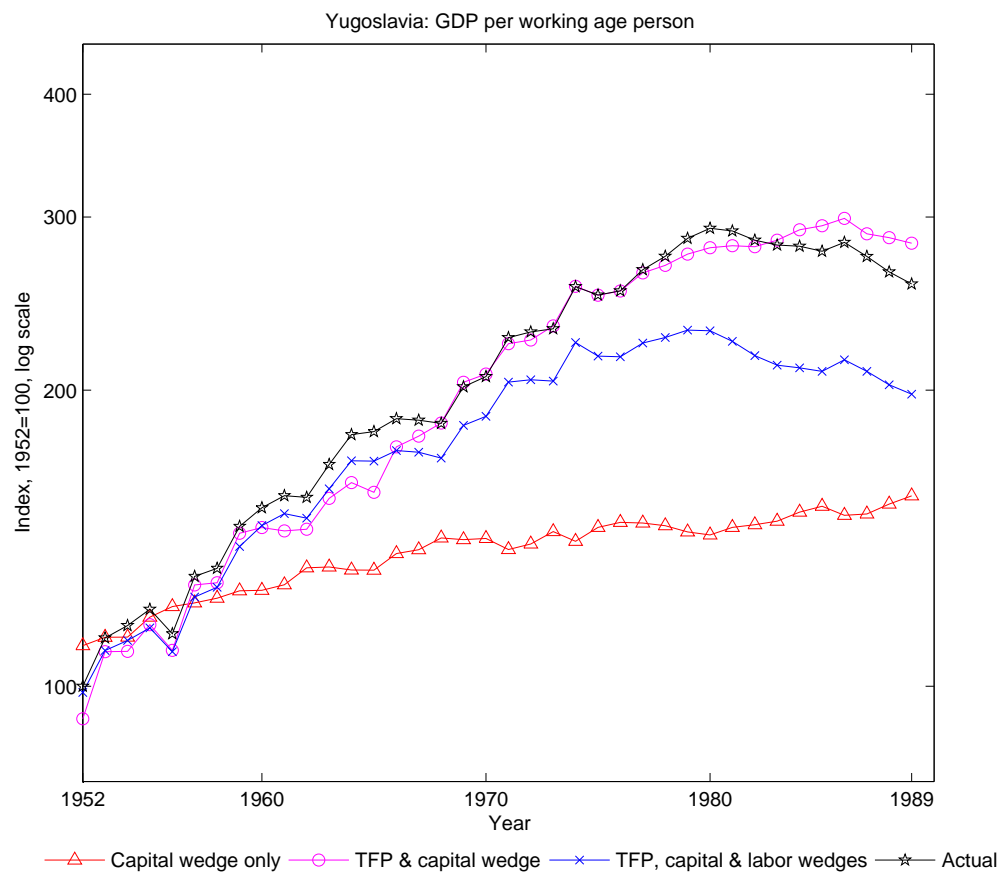


Figure 25: Yugoslav and sample-countries wedges, relative levels, alternative labour data, 195289
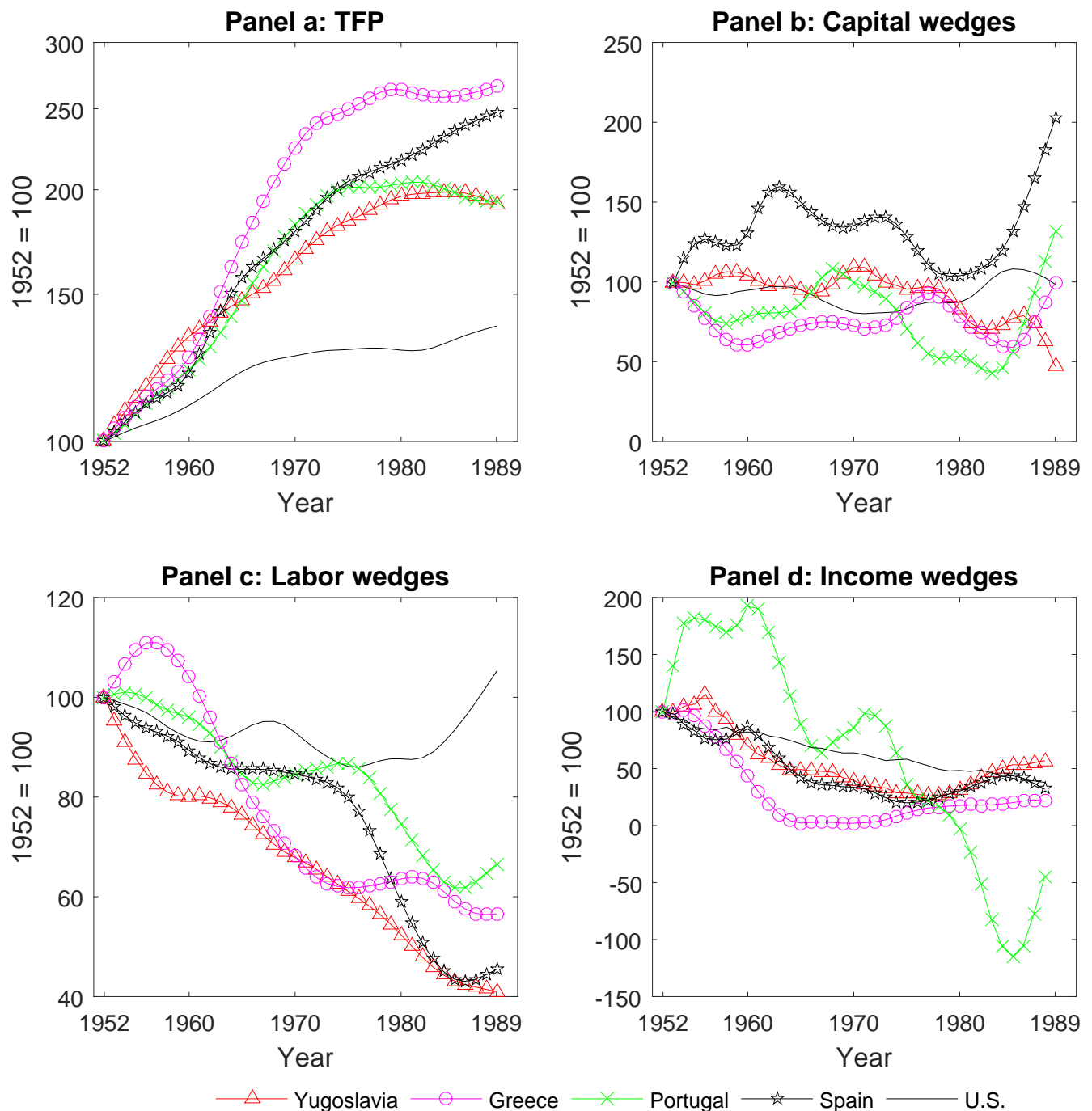
Figure 26: Yugoslav and sample-countries wedges, absolute levels, alternative labour data, 1952-89
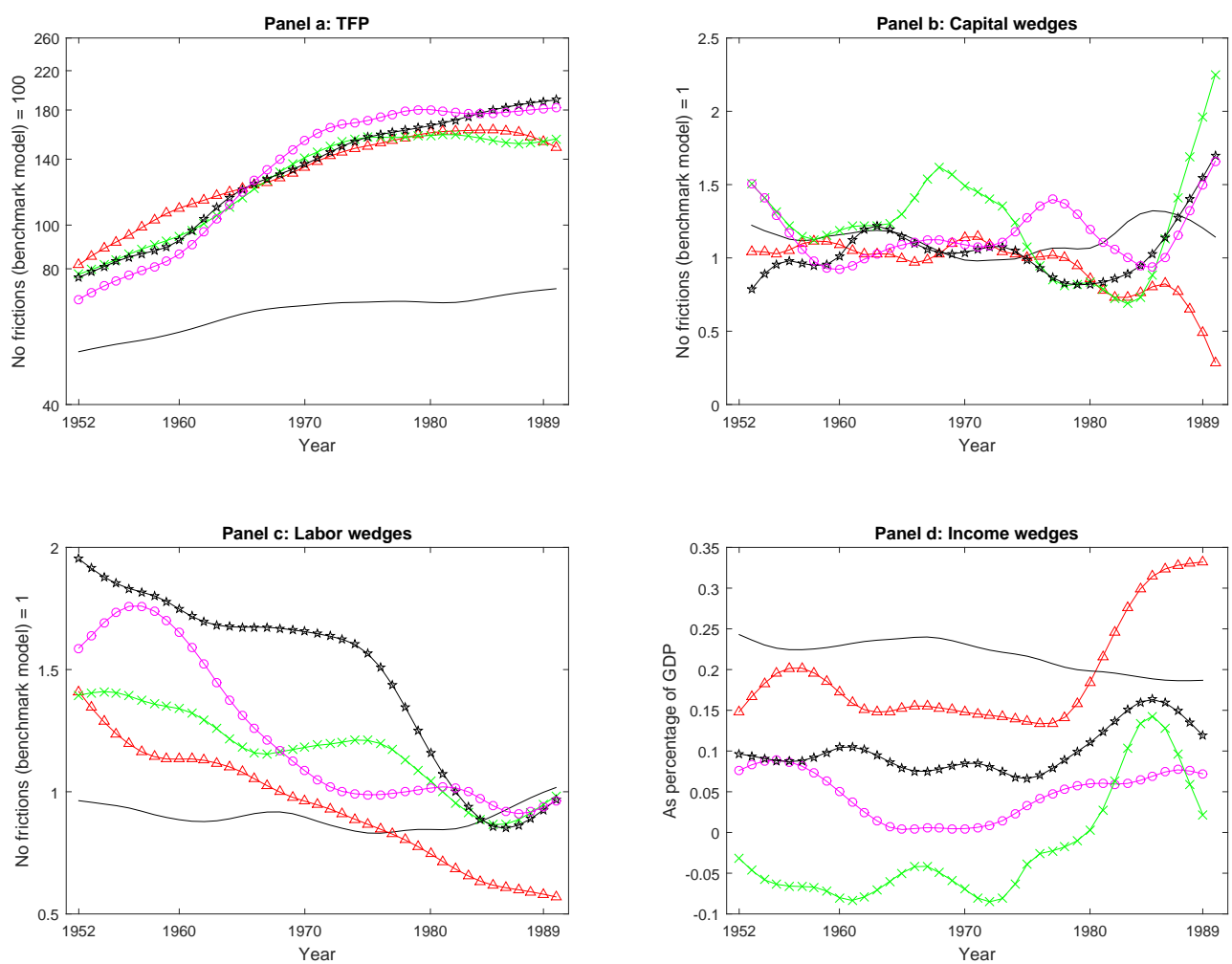

Figure 27: The actual evolution of GDP per capita versus the counterfactual evolution of it (without TFP), alternative labour data, 1952-89

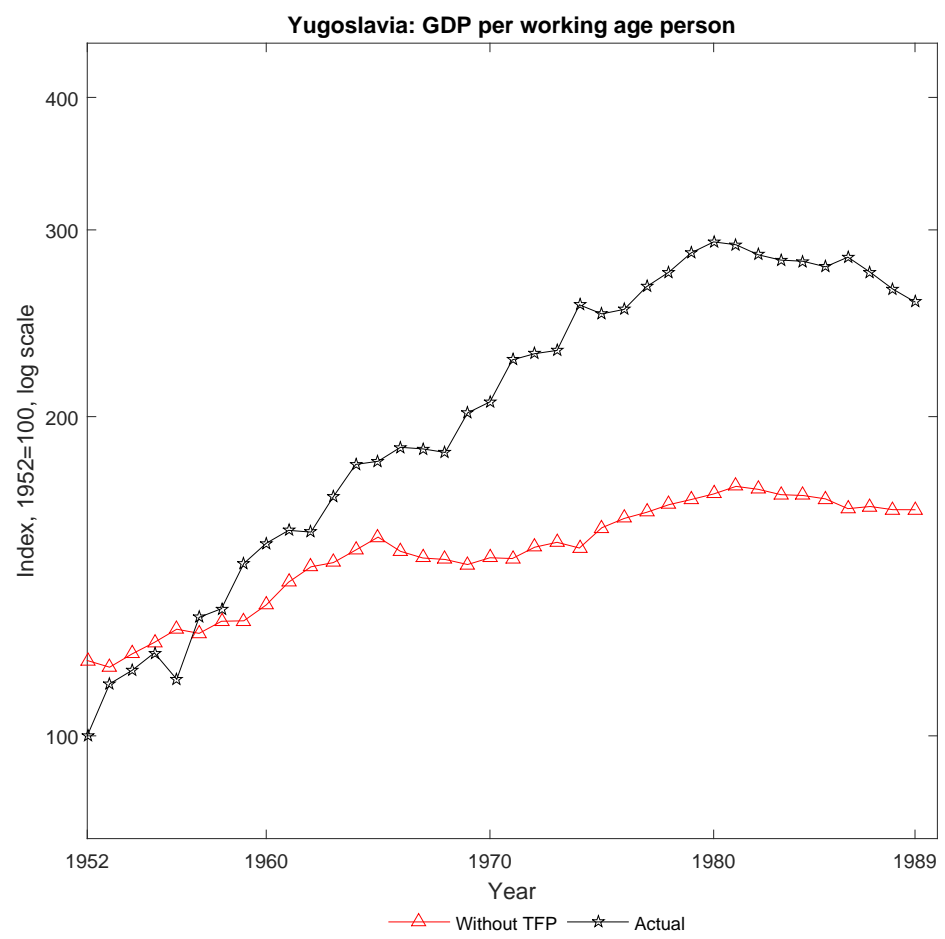


Figure 28: Simulations of GDP per capita versus the actual GDP per capita, alternative labour data, 1952-89

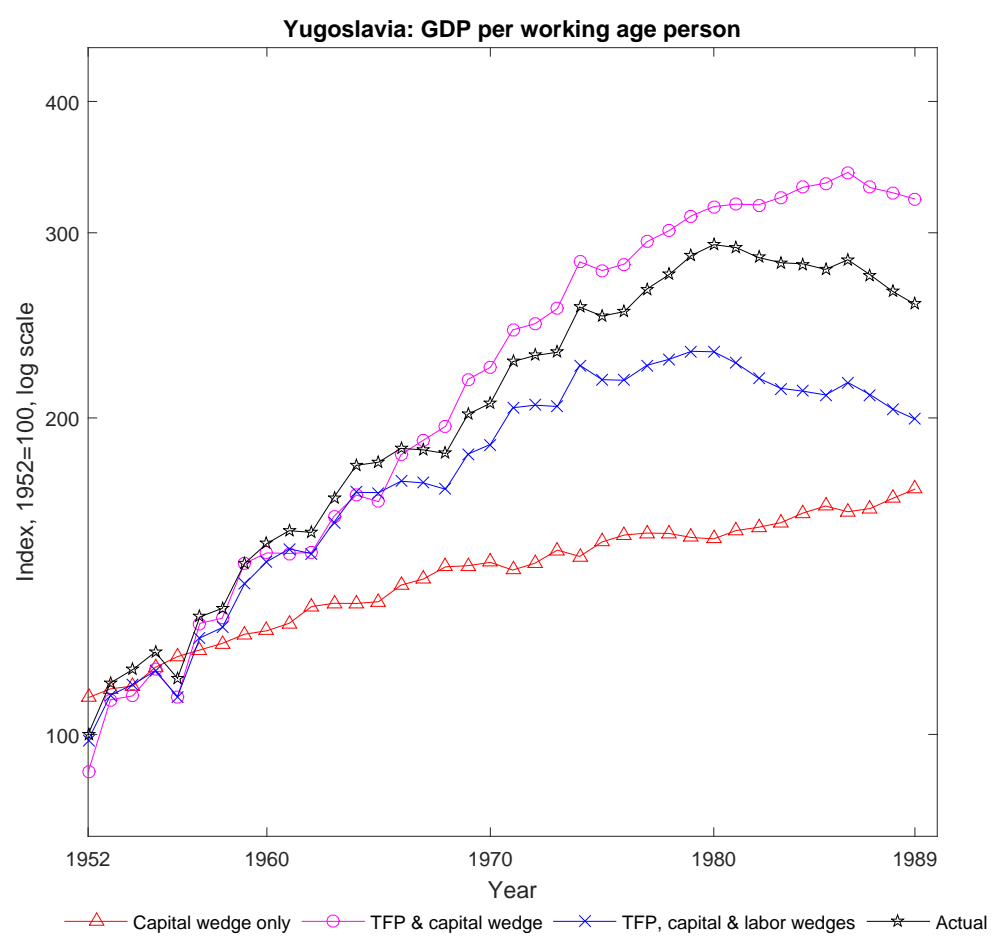


Figure 29: Yugoslav and sample-countries wedges, relative levels, without income wedge, 195289
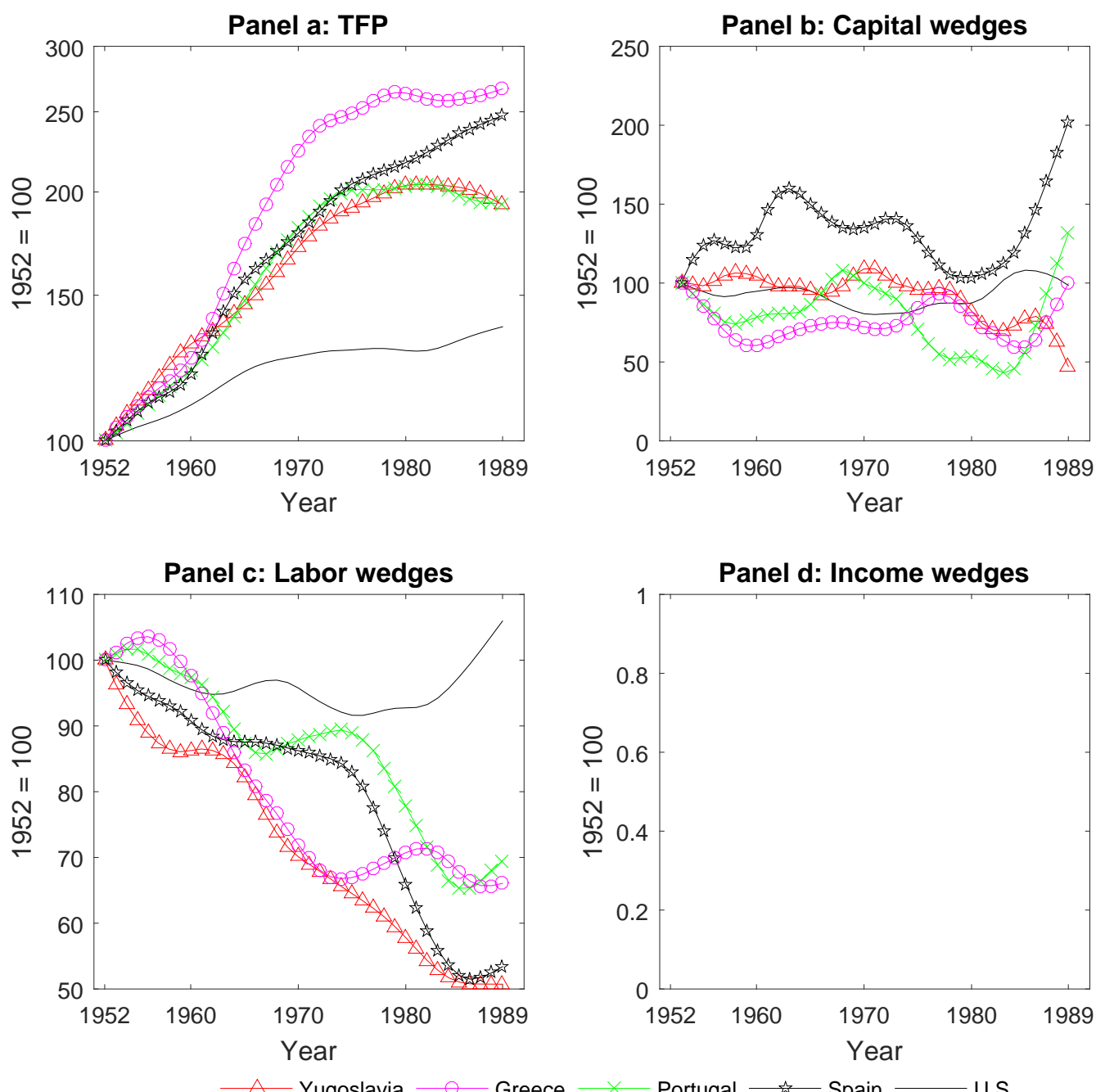
Figure 30: Yugoslav and sample-countries wedges, absolute levels, without income wedge, 195289
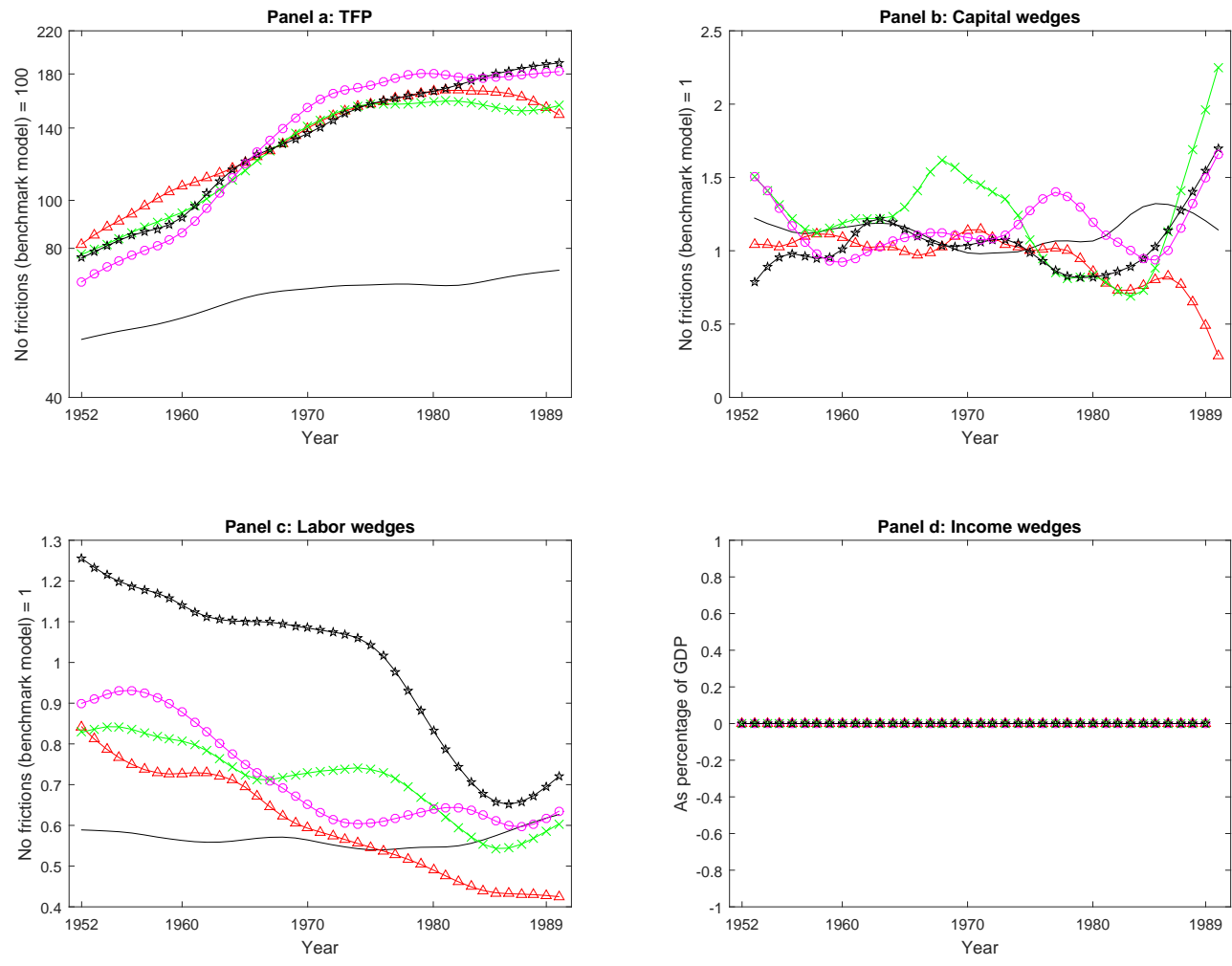

Figure 31: The actual evolution of GDP per capita versus the counterfactual evolution of it (without TFP), without income wedge, 1952-89

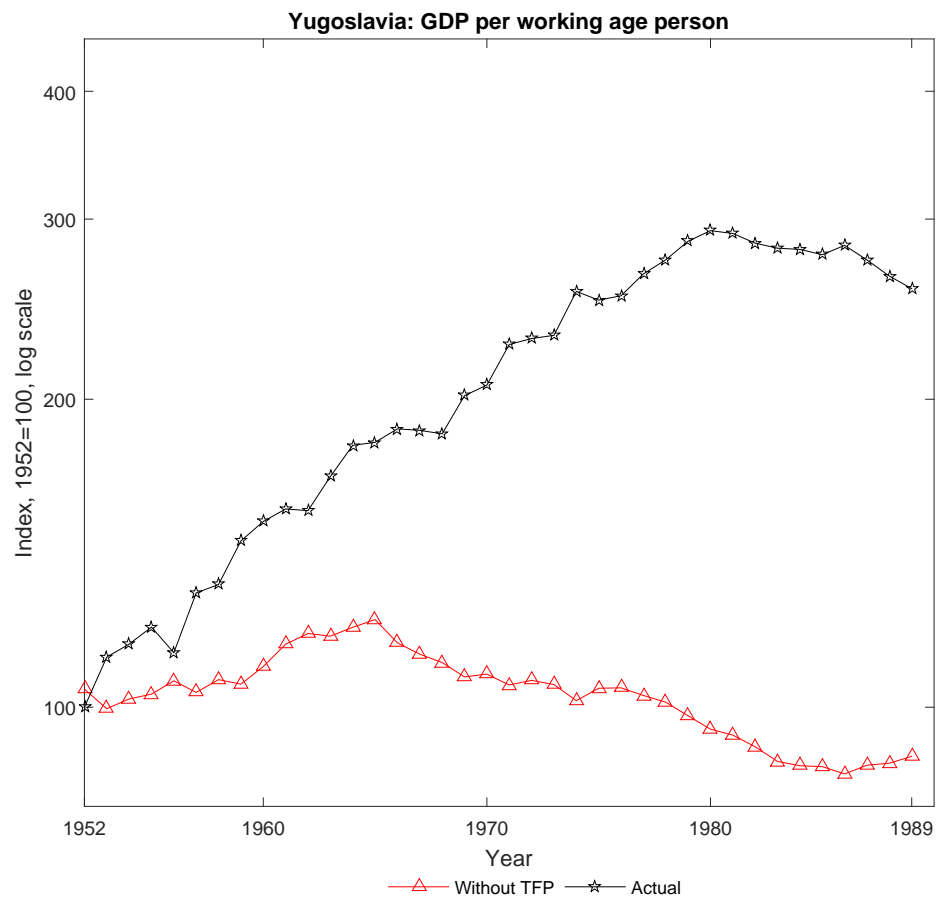


Figure 32: Simulations of GDP per capita versus the actual GDP per capita, without income wedge, 1952-89

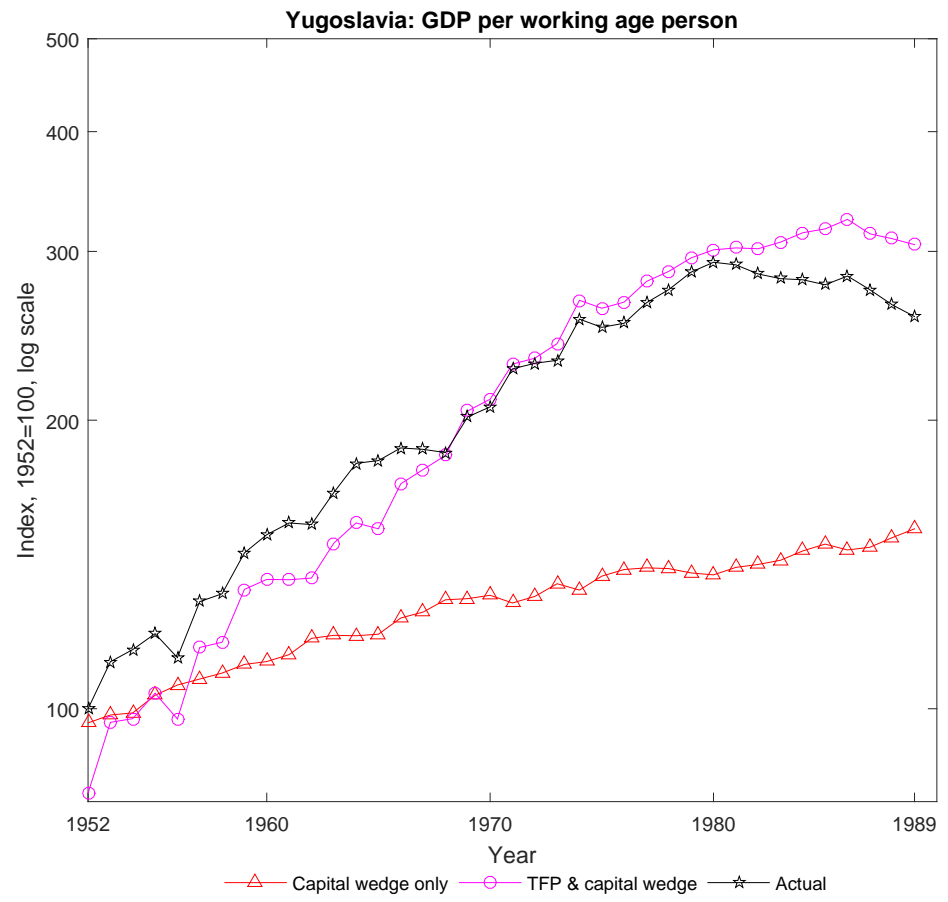

Figure 33: Simulations of GDP per capita versus the actual GDP capita, the contribution of each wedge, without income wedge, 1952-89

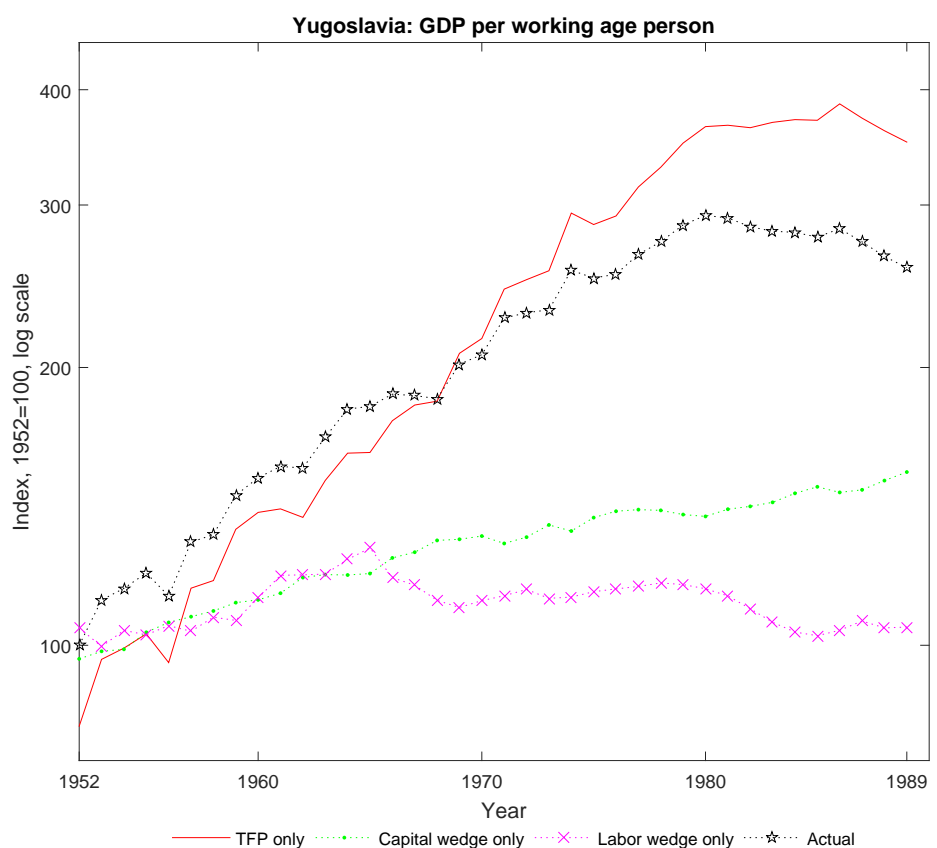


Figure 34: The actual evolution of GDP per capita versus the counterfactual evolution of it (without TFP), without trend growth rate of labour-augmenting technology, 1952-89

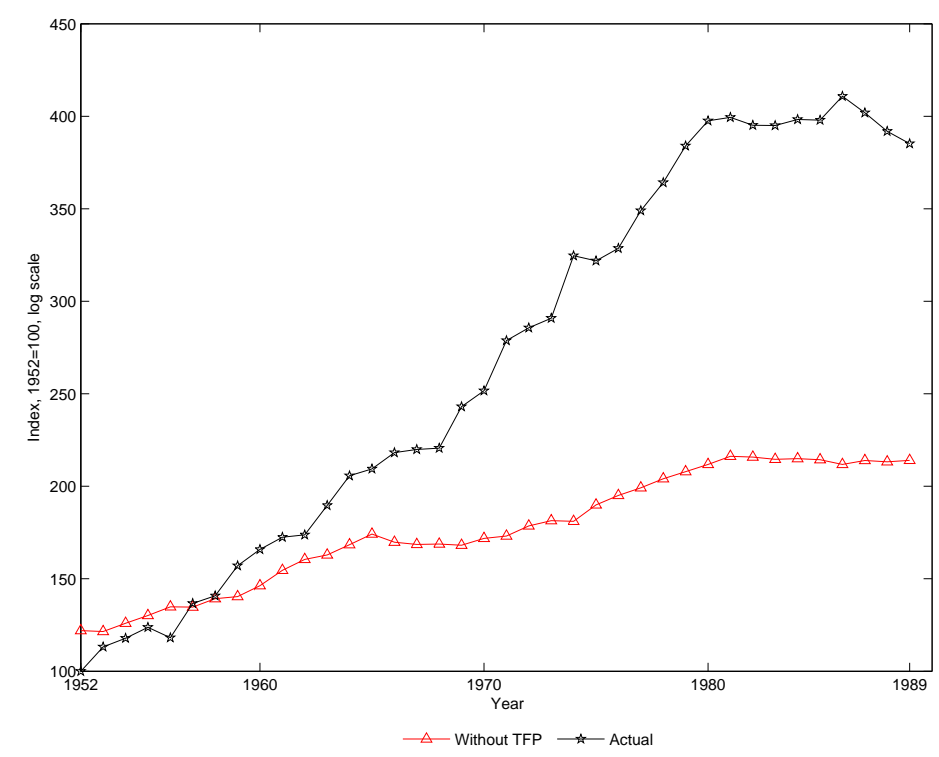

Figure 35: Simulations of GDP per capita versus the actual GDP per capita, without trend growth rate of labour-augmenting technology, 1952-89

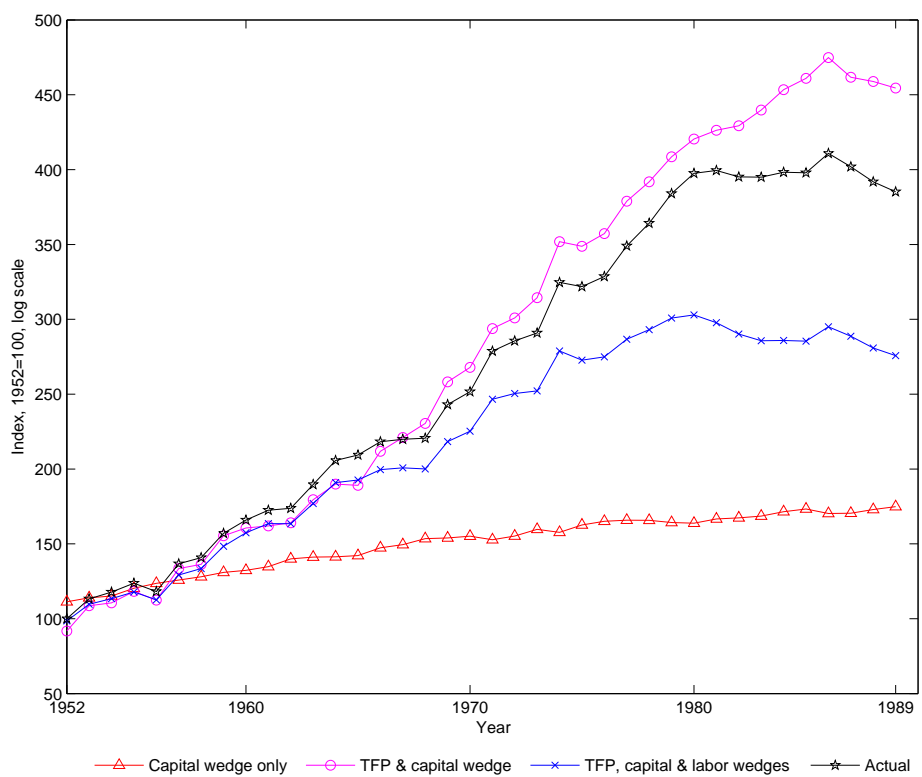


Figure 36: Yugoslav and sample-countries wedges, relative levels, capital share: 0.3, 1952-89
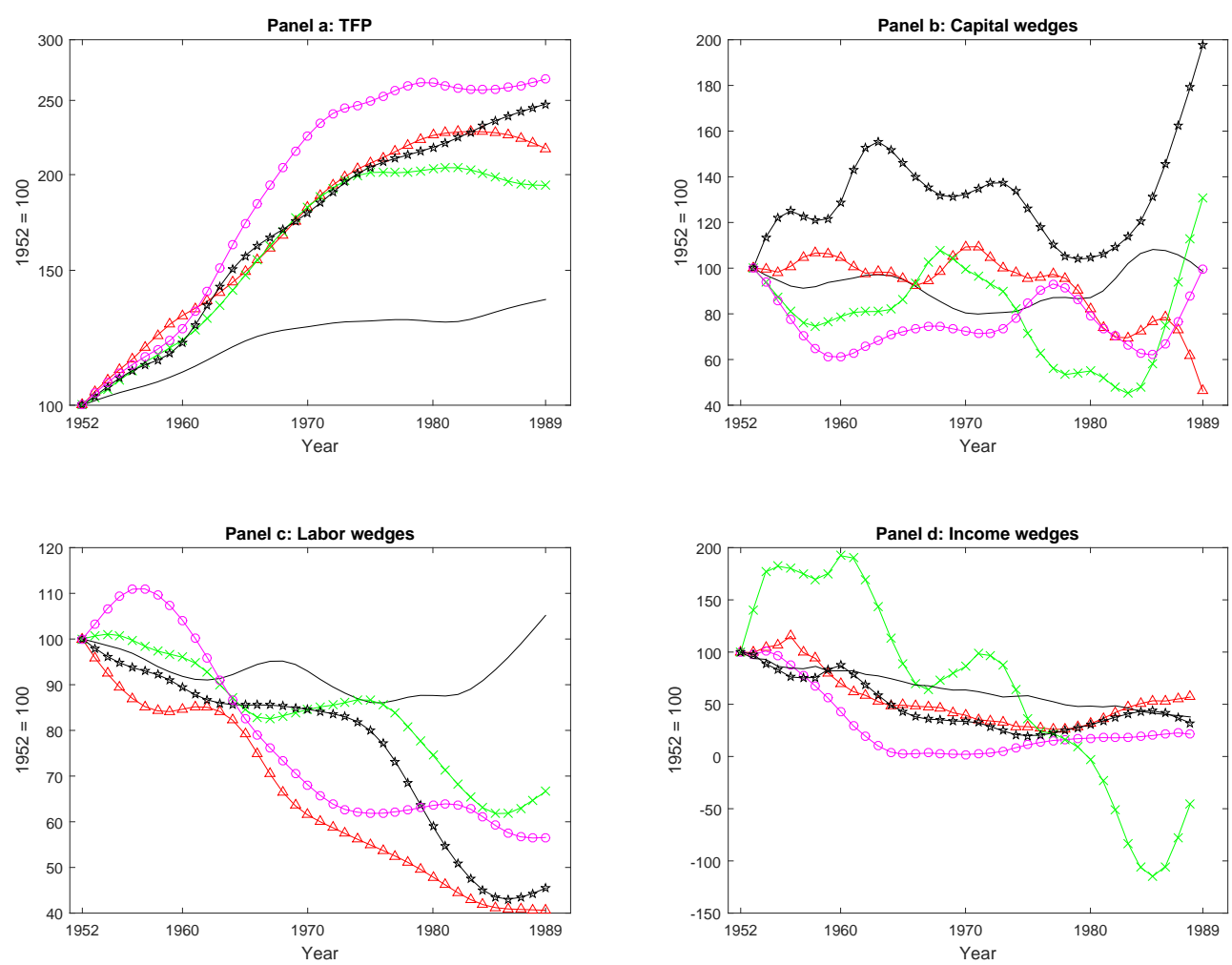

$\triangle$ Yugoslavia $\square$ Greece $\longrightarrow$ Portugal $\longrightarrow$ Spain $\longrightarrow$ U.S. 
Figure 37: Yugoslav and sample-countries wedges, absolute levels, capital share: 0.3, 1952-89
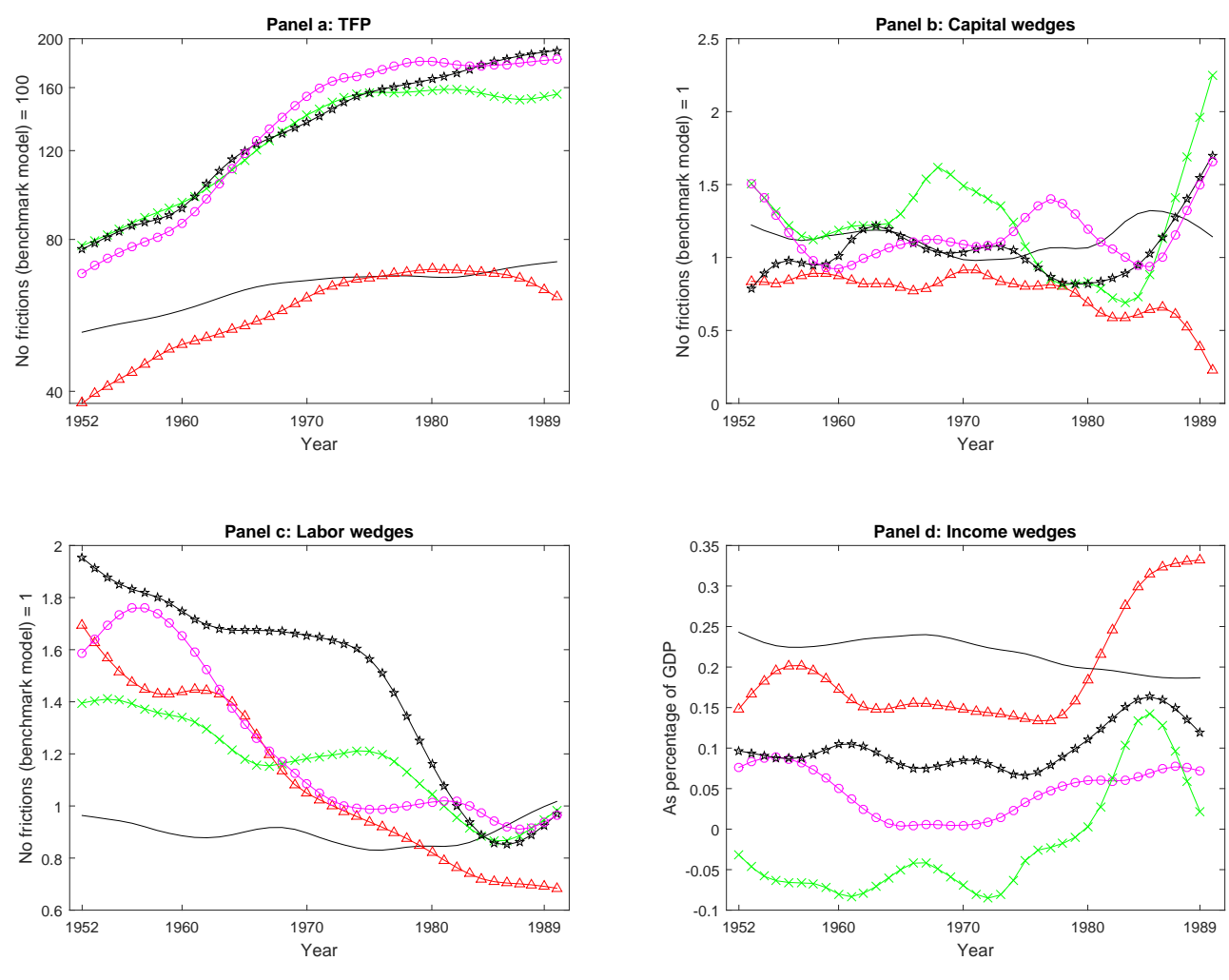

$\triangle$ Yugoslavia $\longrightarrow$ Greece $\longrightarrow$ Portugal $\longrightarrow$ Spain $\longrightarrow$ U.S. 
Figure 38: The actual evolution of GDP per capita versus the counterfactual evolution of it (without TFP), capital share: $0.31952-89$

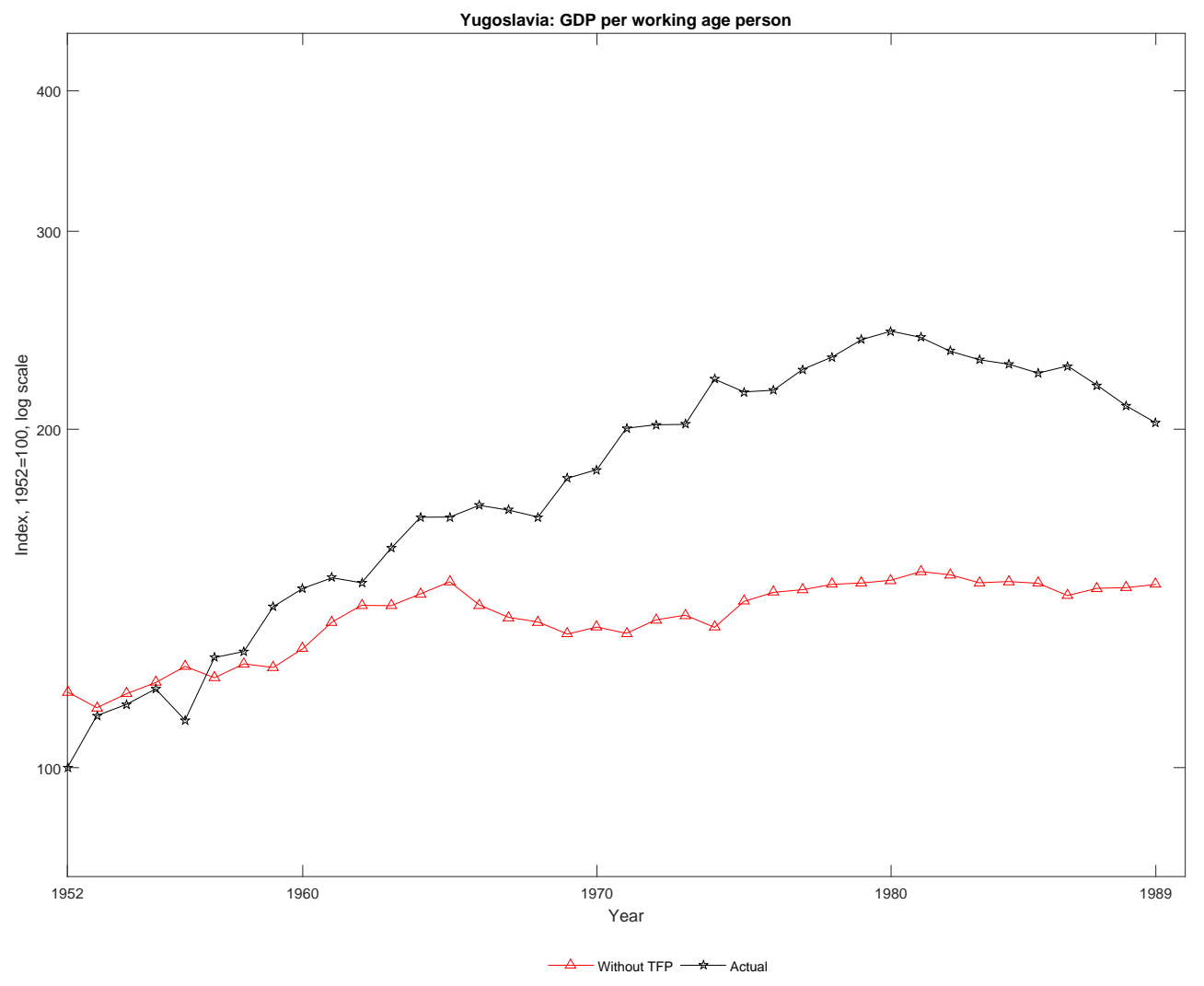


Figure 39: Simulations of GDP per capita versus the actual GDP per capita, capital share: 0.3 1952-89

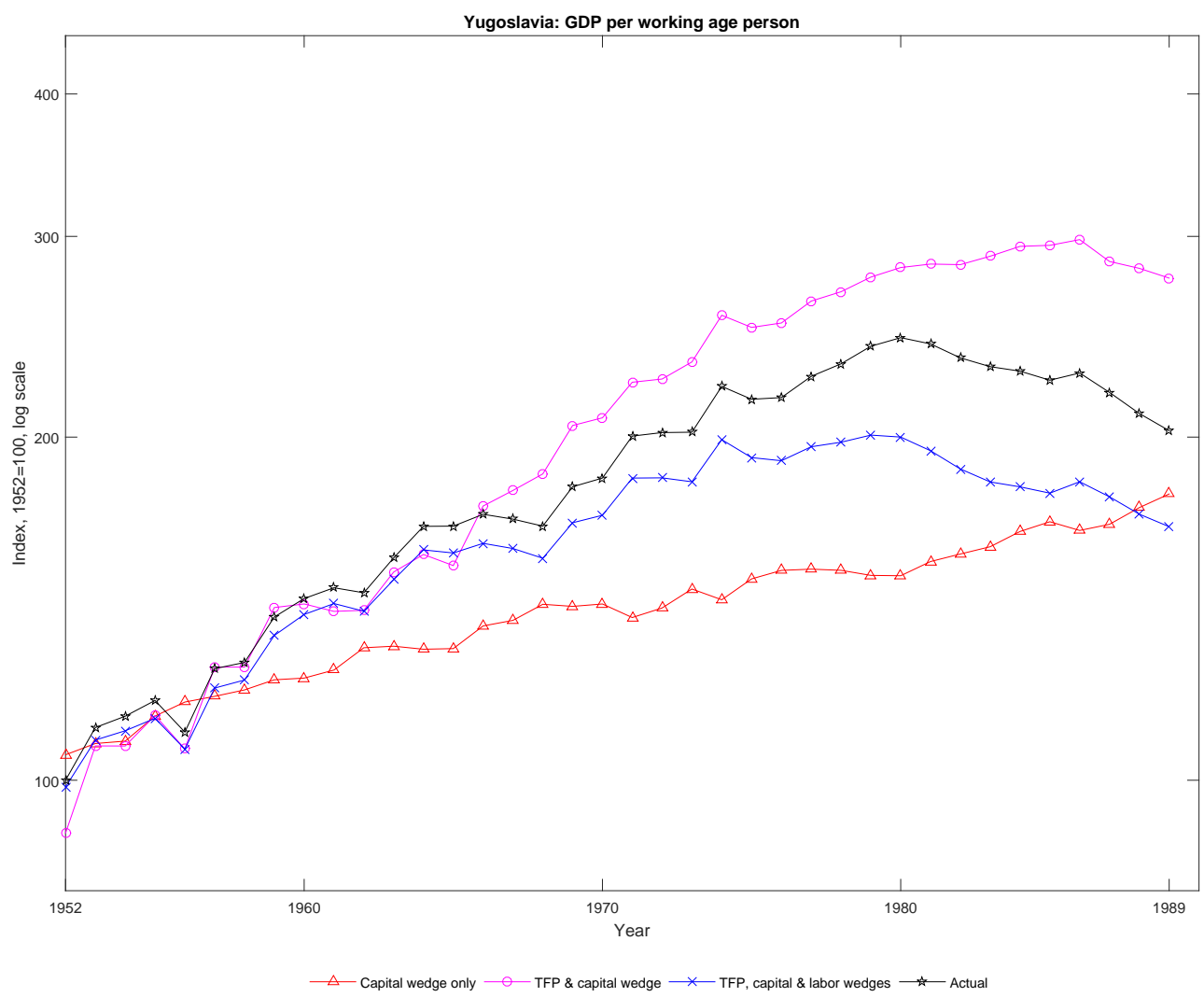


Figure 40: Yugoslav and sample-countries wedges, relative levels, capital share: 0.5, 1952-89
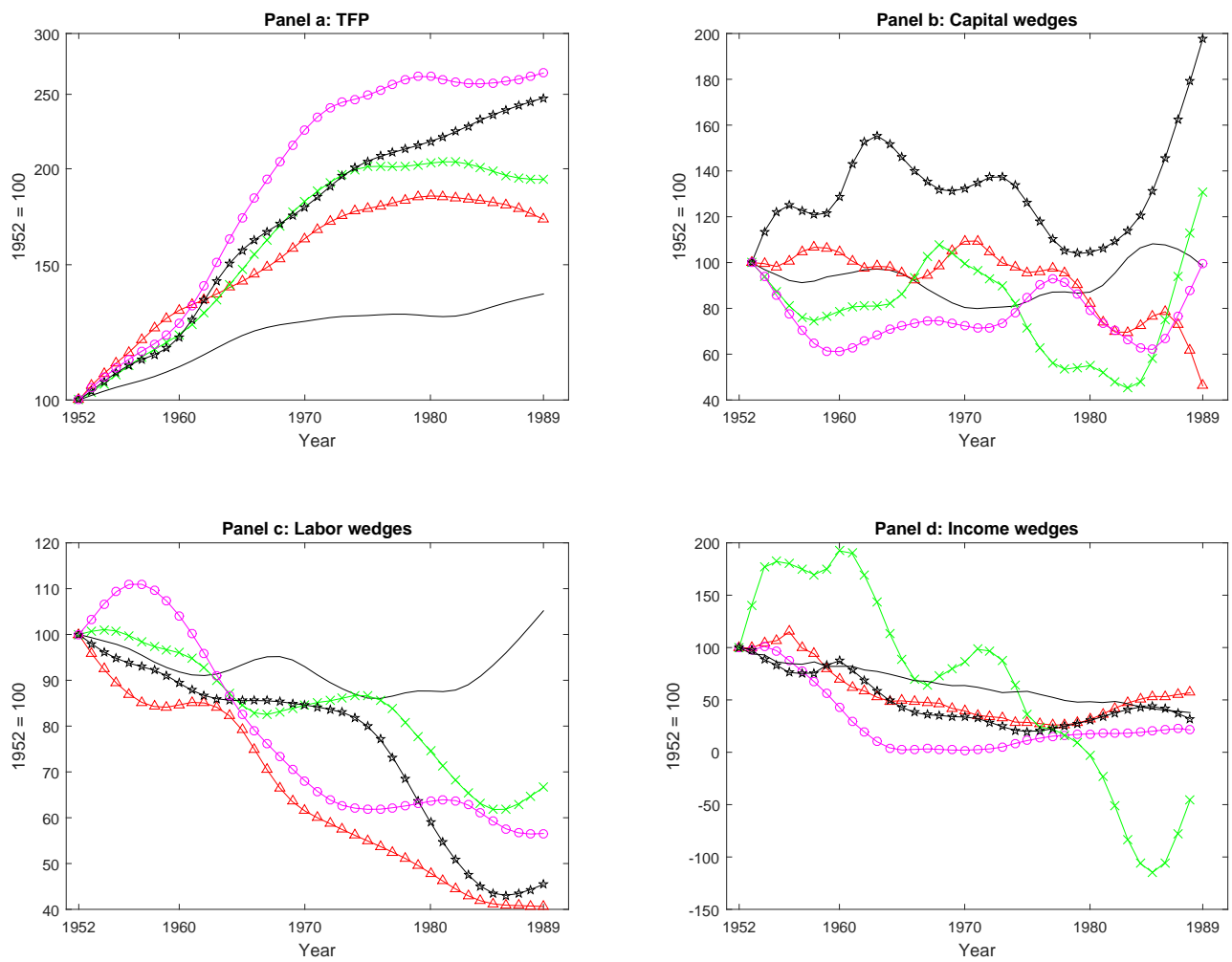
Figure 41: Yugoslav and sample-countries wedges, absolute levels, capital share: 0.5, 1952-89
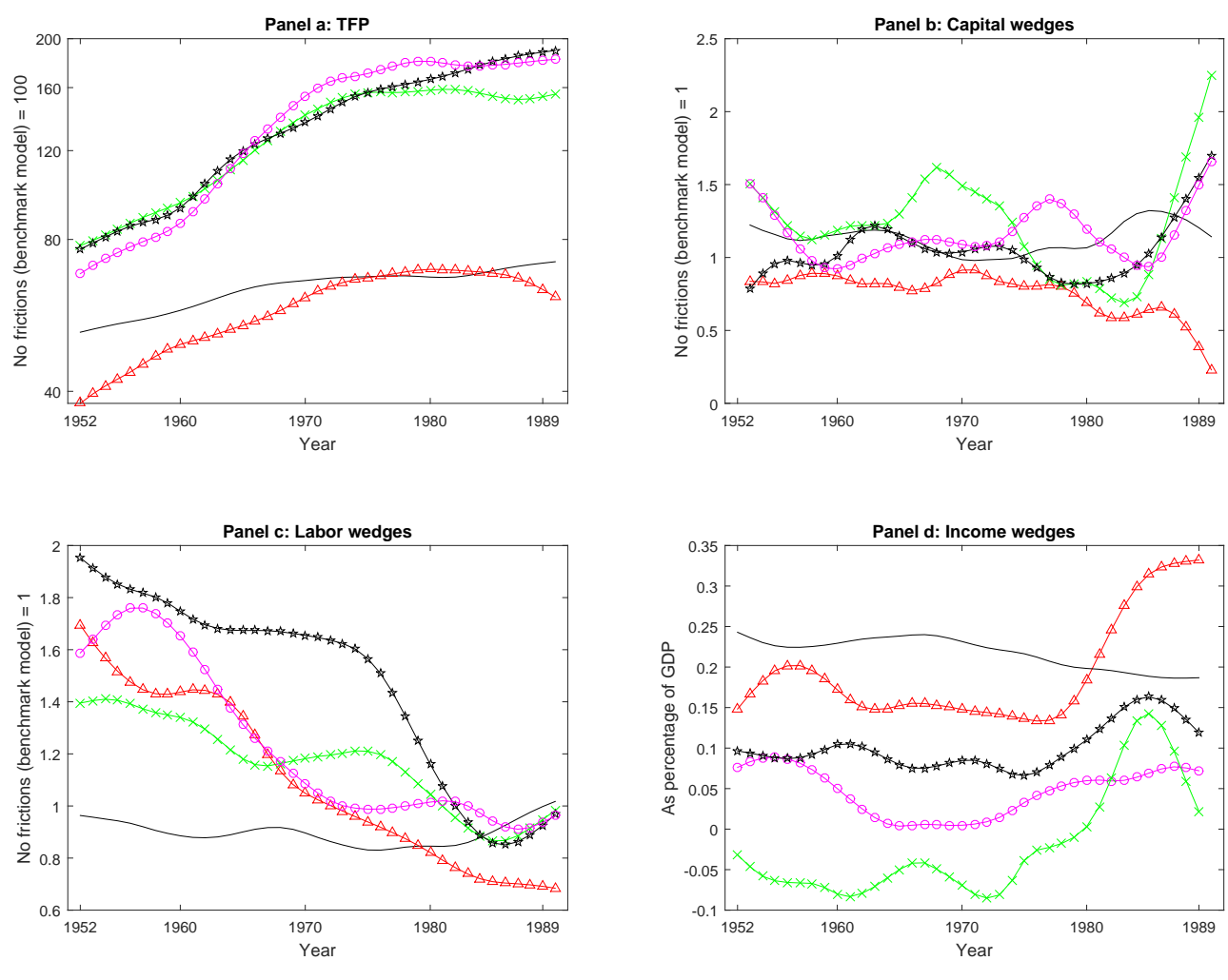

$\triangle$ Yugoslavia $\longrightarrow$ Greece $\longrightarrow$ Portugal $\longrightarrow$ Spain $\longrightarrow$ U.S. 
Figure 42: The actual evolution of GDP per capita versus the counterfactual evolution of it (without TFP), capital share: 0.5, 1952-89

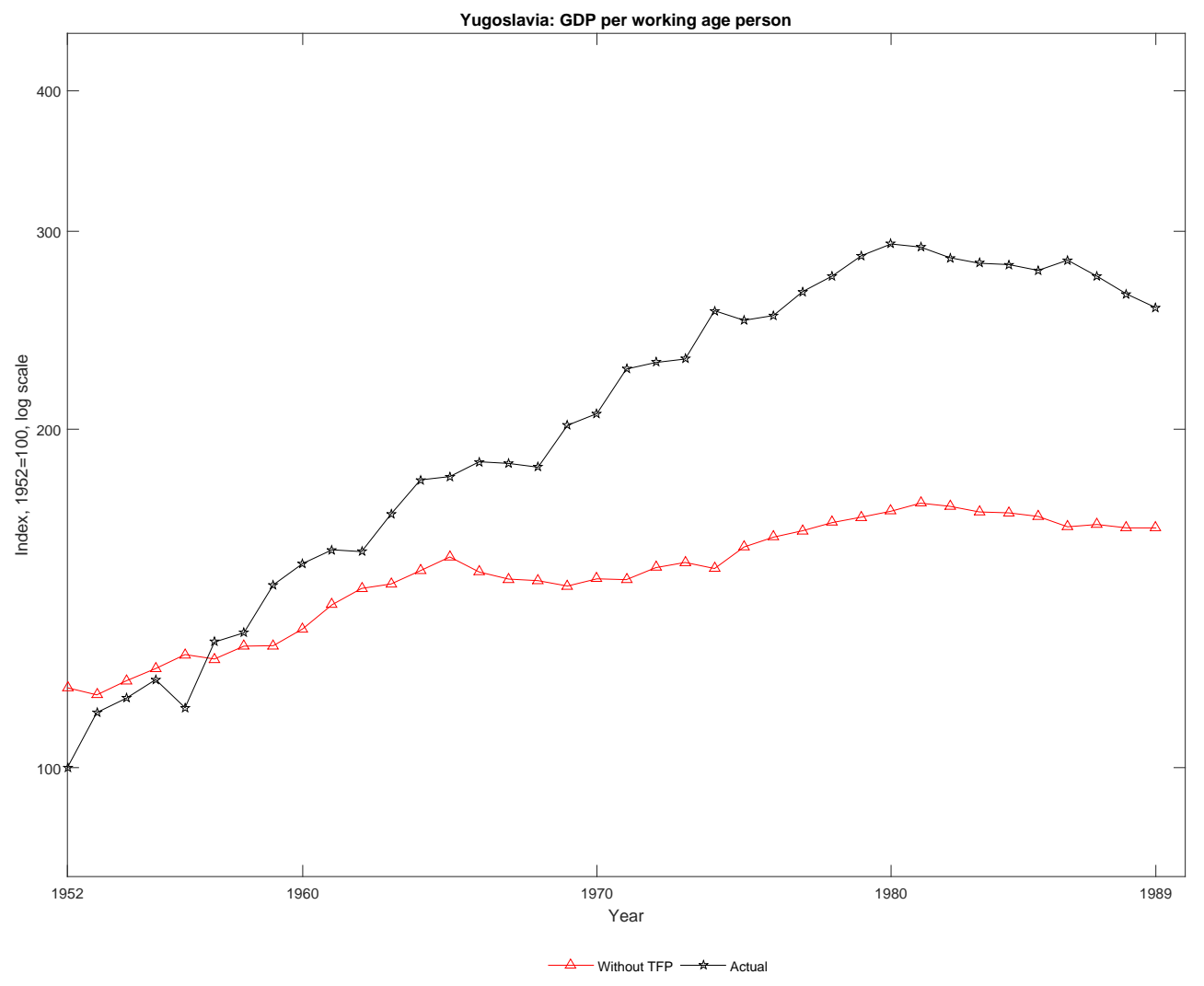


Figure 43: Simulations of GDP per capita versus the actual GDP per capita, capital share: 0.5 , 1952-89

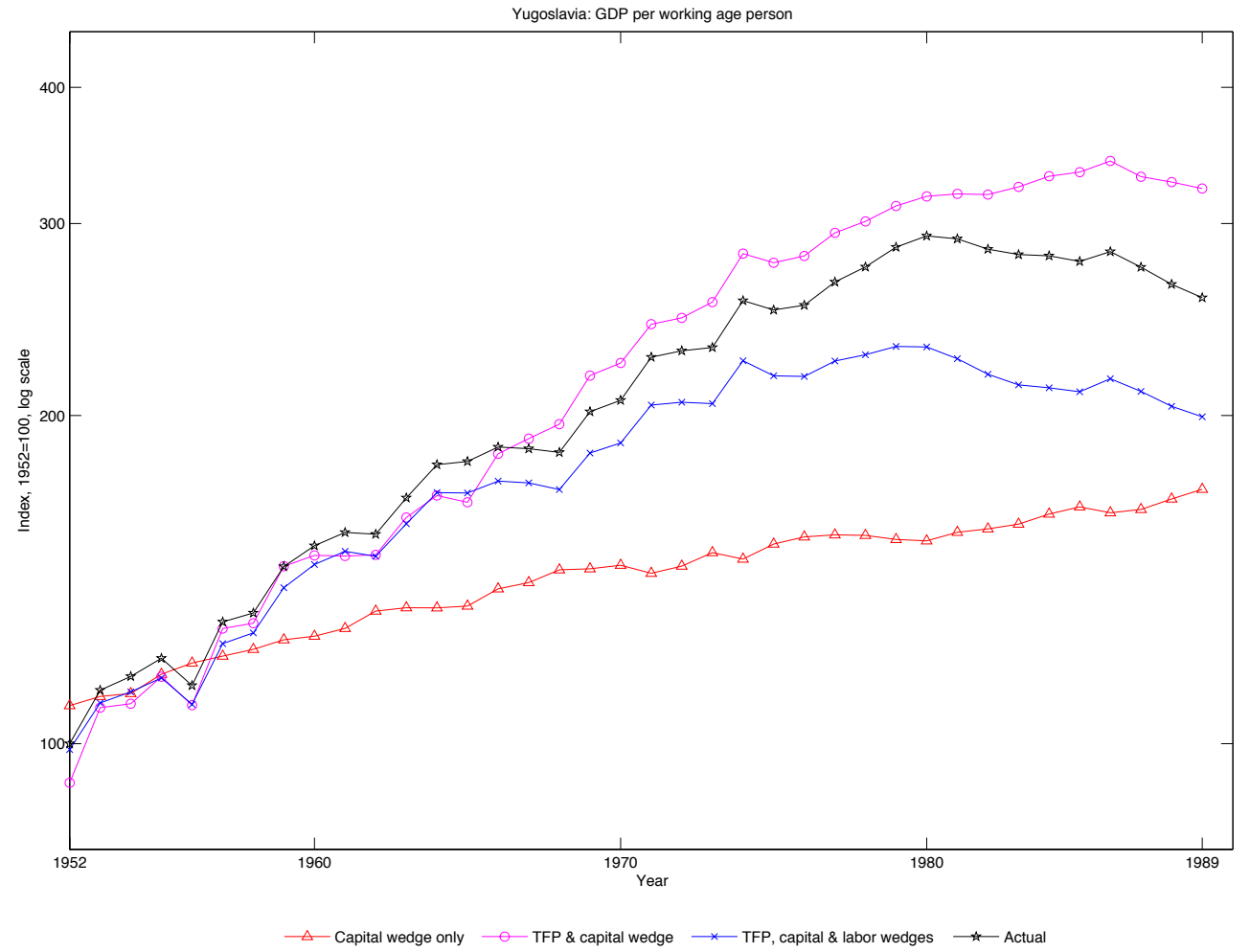




\section{References}

Alcalá, F., And A. Ciccone (2004): "Trade and Productivity," Quarterly Journal of Economics, 119(2), 613-646.

Allcock, J. (1986): "Yugoslavia's Tourist Trade Pot of Gold or Pig in a Poke?," Annals of Tourism Research, 13(4), 565-568.

Allen, R. (2003): Farm to Factory: A Reinterpretation of the Soviet Industrial Revolution. Princeton, NJ: Princeton University Press.

Alton, T. (1970): "Economic Structure and Growth in Eastern Europe," in Economic Developments in Countries of Eastern Europe, ed. by US Congress Joint Economic Committee. Washington, DC: U.S. Government Printing Office.

Alton, T., K. Badach, E. Bass, R. Bakondi, A. Brumaru, J. Bombelles, G. Lazarcik, and G. Staller (1992): "Economic Growth in Eastern Europe, 1975-1991," in Occasional papers Nos. 120-123 of the Research Project on National Income in East Central Europe, ed. by T. Alton. New York, NY: L. W. International Financial Research.

Balassa, B., And T. Bertrand (1970): "Growth Performance of Eastern European Economies and Comparable Western European Countries," American Economic Review: Papers and Proceedings, 60(2), 314-320.

Barro, R., And J. Lee (2013): "A New Data Set of Educational Attainment in the World, 1950-2010," Journal of Development Economics, 104, 184-198.

BEA (Online): "National Economic Accounts and Fixed Assets and Consumer Durable Goods Net of Government," http://www. bea.gov, Accessed: 25th of March 2015.

Bergson, A. (1953): Soviet National Income and Product in 193\%. New York, NY: Columbia University Press.

(1979): "Notes on the Production Function in Soviet Postwar Industrial Growth," Journal of Comparative Economics, 3(2), 116-126.

(1983): "Technological Progress," in The Soviet Economy: Towards the Year 2000, ed. by A. Bergson, and H. Levine. London: Allen and Unwin.

- (1987a): "Comparative Productivity: The USSR, Eastern Europe, and the West," American Economic Review, 77(3), 342-357.

(1987b): "On Soviet Real Investment Growth," Soviet Studies, 39(3), 406-424.

(1989): Planning and Performance in Socialist Economics: The USSR and Eastern Europe. Boston, MA: Unwin Hyman.

Berliner, J. (1976): The Innovation Decision in Soviet Industry. Cambridge, MA: MIT University Press.

BilandžIć, D. (2006): Povijest Izbliza - Memoarski Zapisi - 1945-2005. Zagreb: Prometej.

BičAnić, R. (1973): Economic Policy in Socialist Yugoslavia. Cambridge: Cambridge University Press.

BLS (Online): "Average Hourly and Weekly Earnings of all Employees on Private Non-farm Payrolls," http://www.bls.gov, Accessed: 20th of August 2015. 
Bolt, J., And J. van Zanden (2014): "The Maddison Project: Collaborative Research on Historical National Accounts," Economic History Review, 67(3), 627-651.

Brinca, P., V. V. Chari, P. J. Kehoe, and E. McGrattan (2016): "Accounting for Business Cycles," in Handbook of Macroeconomics, Volume 2, ed. by J. B. Taylor, and H. Uhlig, chap. 13. Amsterdam: Elsevier.

Broadberry, S., And A. Klein (2011): "When and Why did Eastern European Economies Begin to Fail? Lessons from a Czechoslovak/UK Productivity Comparison, 1921-1991," Explorations in Economic History, 48(1), 37-52.

Caselli, F., and D. Wilson (2004): "Importing Technology," Journal of Monetary Economics, 51(1), 1-32.

Chari, V., P. Kehoe, and E. McGrattan (2007): "Business Cycle Accounting," Econometrica, 75(3), 781-836.

Cheremukhin, A., M. Golosov, S. Guriev, and A. Tsyvinski (2015): "The Economy of People's Republic of China From 1953," NBER Working Paper Series No. 21397.

(2017): "The Industrialization and Economic Development of Russia through the Lens of a Neoclassical Growth Model," Review of Economic Studies, 84(2), 613-649.

Christiano, L., and J. Davis (2006): "Two Flaws in Business Cycle Accounting," NBER Working Paper Series No. 12647.

Cole, H., And L. Ohanian (2002): "The U.S. and U.K. Great Depressions Through the Lens of Neoclassical Growth Theory," American Economic Review: Papers and Proceedings, 92(2), $28-32$.

Collins, S., And B. Bosworth (1996): "Economic Growth in East Asia: Accumulation versus Assimilation," Brookings Papers in Economic Activity 2.

Conference BoArd (Online): "Total Economy Database," https://www . conference-board.org/data/economydatabase, Accessed: 25th of March 2015.

DeLong, J., And L. Summers (1991): "Equipment Investment and Economic Growth," Quarterly Journal of Economics, 106(2), 445-502.

Desai, P. (1976): "The Production Function and Technical Change in Postwar Soviet Industry: A Reexemination," American Economic Review, 66(3), 372-381.

Desai, P., and R. Martin (1983): "Efficiency Loss from Resource Misallocation in Soviet Industry," Quarterly Journal of Economics, 98(3), 441-456.

DYker, D. (1990): Yugoslavia: Socialism, Development and Debt. London: Routledge.

Easterly, W., and S. Fischer (1995): "The Soviet Economic Decline," World Bank Economic Review, 9(3), 341-371.

Estrin, S. (1983): Self-Management: Economic Theory and Yugoslav Practice. Cambridge: Cambridge University Press.

Federal Reserve Bank of ST. Louis (Online): "Capacity Utilization: Total Industry," https://fred.stlouisfed.org/series/TCU, Accessed: 15th of June 2016.

Feenstra, R., R. InklaAr, and M. Timmer (2015): "The Next Generation of the Penn World Table," American Economic Review, 105(10), 3150-3182. 
Frenkel, J., and M. Taylor (1993): "Money, Demand and Inflation in Yugoslavia, 19801989," Journal of Macroeconomics, 15(3), 455-481.

Gerschenkron, A. (1947): "The Soviet Indices of Industrial Production," Review of Economics and Statistics, 29(4), 217-226.

Gomulka, S. (1977): "Slowdown in Soviet Industrial Growth," European Economic Review, 12(1), 37-49.

Hall, R., and C. Jones (1999): "Why Do Some Countries Produce So Much More Output per Worker than Others," Quarterly Journal of Economics, 114(1), 83-116.

Hamilton, J. (2013): "Historical Oil Shocks," in Routledge Handbook of Major Events in Economics History, ed. by R. Parker, and R. Whaples. New York, NY: Routledge Taylor and Francis Group.

Herrendorf, B., R. Rogerson, and A. Valentinyi (2014): "Growth and Structural Transformation," in Handbook of Economic Growth, Volume 2B, ed. by D. Aghion, and S. Durlauf. Amsterdam: Elsevier North-Holland.

Horvat, B. (1971): "Yugoslav Economic Policy in the Post-War Period: Problems, Ideas, Institutional Developments," American Economic Review: Supplement, Surveys of National Economic Policy Issues and Policy Research, 61(3), 71-169.

Hsieh, C.-T., And P. Klenow (2009): "Misallocation and Manufacturing TFP in China and India," Quarterly Journal of Economics, 124(4), 1403-1448.

Hulten, C., and F. Wykoff (1981): "The Measurement of Economic Depreciation," in Depreciation, Inflation and the Taxation of Income from Capital, ed. by C. Hulten. Washington, DC: Urban Institute Press.

Iacopetta, M. (2010): "Phases of Economic Development and the Transition Dynamics of an Innovation-Education Growth Model," European Economic Review, 53(2), 317-330.

ILO (Online): "Total and Economically Active Population, in LABORSTA," http:// laborsta.ilo.org/, Accessed: 24th of June 2012.

Jerome, R. (1985): "Estimates of Sources of Growth in Bulgaria, Greece, and Yugoslavia, 1950-1980," Journal of Comparative Economic Studies, 27(3), 31-82.

Jovanov, N. (1989): Sukobi: Protagonisti Latentnih i Otvorenih Društvenih Konflikata. Nikšič: Univerzitetska Riječ.

Kornai, J. (1979): "Resource-Constrained versus Demand-Constrained Systems," Econometrica, 47(4), 801-819.

(1980): Economics of Shortage. Amsterdam: North Holland Press.

Krugman, P. (1994): "The Myth of Asia's Miracle," Foreign Affairs, 73(6), 62-78.

Kukić, L. (2017): "Regional Development under Socialism: Evidence from Yugoslavia," Working Paper, Print.

Lampe, J. (2000): Yugoslavia as History, Twice there was a Country. Cambridge: Cambridge University Press.

Lowinger, J. (2009): "Economic Reform and the "Double Movement" in Yugoslavia: An Analysis of Labor Unrest and Ethno-Nationalism in the 1980s," Unpublished PhD Dissertation, John Hopkins University, Baltimore, Maryland. 
Lu, S.-S. (2012): "East Asian Growth Experience Revisited from the Perspective of a Neoclassical Model," Review of Economic Dynamics, 15(3), 359-376.

Maddison, A. (1988): "Ultimate and Proximate Growth Causality: A Critique of Mancur Olson on the Rise and Decline of Nations," Scandinavian Economic History Review, 36(2), $25-29$.

(Online): "Historical Statistics of the World Economy: 1-2008," http://www.ggdc . net/maddison/oriindex.htm, Accessed: 24th of June 2012.

Madsen, J. B. (2007): "Technology Spillover Through Trade and TFP Convergence: 135 Years of Evidence for the OECD Countries," Journal of International Economics, 72(2), 464-480.

MADŽAR, L. (1985): "Revalorizacija Zaliha, Fiktivna Akumulacija i Iluzija Rasta," Ekonomist, 38(3-4), 327-349.

Meade, J. (1972): "The Theory of Labour-Managed Firms and of Profit Sharing," Economic Journal, 82(326), 402-428.

Milenkovitch, D. (1971): Plan and Market in Yugoslav Economic Thought. New Haven, CT: Yale University Press.

Mitchell, B. (2013): International Historical Statistics: 1750-2010. London: Palgrave Macmillian.

Nishimizu, M., And J. PAge (1982): "Total Factor Productivity Growth, Technological Progress and Technical Efficiency Change: Dimensions of Productivity Change in Yugoslavia, 1965-78," Economic Journal, 92(368), 920-936.

OECD (1965): OECD Economic Surveys: Yugoslavia. Paris: OECD Publishing. (1990): OECD Economic Surveys: Yugoslavia. Paris: OECD Publishing.

Ofer, G. (1987): "Soviet Economic Growth: 1928-1985," Journal of Economic Literature, 25(4), 1767-1833.

Ohanian, L., A. Raffo, and R. Rogerson (2008): "Long-term Changes in Labor Supply and Taxes: Evidence from OECD Countries, 1956-2004," Journal of Monetary Economics, 55(8), 1353-1362.

Olson, M. (1982): The Rise and Decline of Nations. New Haven, CT: Yale University Press.

Paquet, A., And B. Robidoux (2001): "Issues on the Measurement of the Solow Residual and the Testing of its Exogeneity: Evidence from Canada," Journal of Monetary Economics, $47(3), 595-612$.

Pejovich, S. (1980): "The Economic Position of the Enterprise in the Yugoslav Economy," Statsvetenskpalig Tidskrift, 5 .

Prados de la Escosura, L., And J. Rosés (2010): "Long-run Estimates of Physical Capital in Spain, 1850-2000," in Research in Economic History (27), ed. by A. Field. Amsterdam: Elsevier North-Holland.

Prescott, E. (2004): "Why do Americans Work so Much More than Europeans?," NBER Working Paper Series No. 10316.

Prout, C. (1985): Market Socialism in Yugoslavia. Oxford: Oxford University Press. 
RAJAK, S. (2011): Yugoslavia and the Soviet Union in the Early Cold War: Reconciliation, Comradeship, Confrontation, 1953-5\%. London: Routledge.

Rozman, G. (2014): The Chinese Debate about Soviet Socialism, 1978-1985. Princeton, NJ: Princeton University Press.

Rusek, A. (1980): "Industrial Growth in Czechoslovakia 1971-1985: Total Factor Productivity and Capital-Labor Substitution," Journal of Comparative Economics, 13(2), 301-313.

SAPIR, A. (1980): "Economic Growth and Factor Substitution: What Happened to the Yugoslav Miracle?," Economic Journal, 90(385), 294-313.

Savezni Zavod za Statistiku (1948, 1953, 1961, 1971, 1981): Popis Stanovništva. Beograd: Savezni Zavod za Statistiku.

(1950-1954): Vitalna Statistika. Beograd: Savezni Zavod za Statistiku.

(1952-1991): Statistički Godišnjak SFR Jugoslavije. Beograd: Savezni Zavod za Statis-

tiku.

(1955-1989): Demografska Statistika. Beograd: Savezni Zavod za Statistiku.

(1982-1989): Investicije. Beograd: Savezni Zavod za Statistiku.

(1983a): Investicije u Osnovna Sredstva SFR Jugoslavije, Socijalističkih Republika i Socijalističkih Autonomnih Pokrajina, 1952-1981, u Cenama 1972. Beograd: Savezni Zavod za Statistiku.

(1983b): Osnovna Sredstva Privrede Društvenog Sektora SFR Jugoslavije, Socijalističkih Republika i Socijalističkih Autonomnih Pokrajina, 1952-1981, u cenama 1972. Beograd: Savezni Zavod za Statistiku.

\section{Statistiku.}

(1989): Jugoslavija 1918-1988: Statistički Godišnjak. Beograd: Savezni Zavod za

Silva, E., And P. Lains (2013): "Capital Formation and Long-Run Growth: Evidence from Portuguese Data, 1910-2010," Working Paper, Print.

Simon, G. (2013): "An Economic History of Socialist Yugoslavia," Unpublished Manuscript.

Staller, G. (1986): "Industrial production in Yugoslavia," in Occasional papers Nos.90-94 of the Research Project on National Income in East Central Europe, ed. by T. Alton. New York, NY: L. W. International Financial Research.

Stanojević, M. (2003): "Formation of the Slovenian pattern: The Strike Wave and Industrial Relations 'Rigidities," South-East Europe Review for Labour and Social Affairs, 3, 17-30.

Statistics Portugal (Online): "Portuguese National Accounts - ESA2010, base 2011," http: //www.ggdc.net/maddison/oriindex.htm, Accessed: 23 August 2015.

UN (Online): "World Population Prospects," http://esa.un.org/unpd/wpp/, 20th of August 2015.

Uvalić, M. (1992): Investment and Property Rights in Yugoslavia. Cambridge: Cambridge University Press.

VAN ARK, B. (1996): "Convergence and Divergence in the European Periphery: Productivity in Eastern and Southern Europe in Retrospect," in Quantitative Aspects of Postwar European Economic Growth, ed. by B. van Ark, and N. Crafts. Cambridge: Cambridge University Press. 
VAneK, J. (1970): The General Theory of Labor-Managed Market Economies. Ithaca, NY: Cornell University Press.

VAneK, J., And M. JovičIć (1975): "Capital Market and Income Distribution in Yugoslavia: A Theoretical and Empirical Analysis," Quarterly Journal of Economics, 89(3), 432-443.

Vinski, I. (1978): Fiksni Fondovi Jugoslavije i Njenih Republika i Pokrajina od 1953. do 1973. Beograd: Ekonomika.

Vonyó, T. (2008): "Post-war Reconstruction and the Golden Age of Economic Growth," European Review of Economic History, 12(2), 221-241.

(2010): "Socialist Industrialization or Post-War Reconstruction: Understanding Hungarian Economic Growth, 1949-1967," Journal of European Economic History, 39(2), 253-300.

(2017): "War and Socialism: Why Eastern Europe Fell Behind Between 1950 and 1989," Economic History Review, 70(1), 248-270.

Vonyó, T., And A. Klein (2017): "Why Did Socialism Fail? The Role of Factor Inputs Reconsidered," CAGE Working Paper Series, No. 276.

Ward, B. (1958): "The Firm in Illyria: Market Syndicalism," American Economic Review, $48(4), 566-589$.

Weitzman, M. (1970): "Soviet Postwar Economic Growth and Capital-Labor Substitution," American Economic Review, 60(4), 676-692. 